TABAJARA MEDEIROS DE REZENDE FILHO

\title{
DO PROTECIONISMO DO EMPREGADO À PROTEÇÃO DO TRABALHADOR: DESAFIOS DA FLEXICURITY
}

\author{
Tese de Doutorado em Direito do Trabalho \\ Orientador: Professor Titular Nelson Mannrich
}

Faculdade de Direito da Universidade de São Paulo

São Paulo

2013 


\section{ÍNDICE}

Resumo

pág. 03

Abstract

pág. 04

Riassunto

pág. 05

Introdução

pág. 06

I. A Crise do Direito do Trabalho

pág. 14

II. Direito do Trabalho e Direitos Fundamentais

pág. 31

III. Direito Constitucional do Trabalho - Hermenêutica

de Normas Constitucionais Trabalhistas

pág. 40

IV. O Trabalho Decente

pág. 44

V. Flexibilização do Direito do Trabalho

pág. 47

VI. Tipologias Contratuais Flexíveis

pág. 57

VII. Flexicurity - Definição - Análise - Aplicabilidade

pág.69

VIII. Novos Paradigmas - Expansão do Objeto do Direito do Trabalho

pág. 90

IX. Características Comuns do Trabalho Humano

pág. 99

X. Do Núcleo Essencial de Direitos de Todos os Trabalhadores

pág. 105

XI. Desafios da Flexicurity e o Modelo Brasileiro de Relações de Trabalho

pág. 118

Conclusões

pág. 134

Bibliografia

pág. 144 


\section{RESUMO}

O Direito do Trabalho tradicional, fundamentado no protecionismo do empregado em sentido clássico, está em crise. Dentre os fatores que desencadearam a crise merecem destaque as transformações do mercado de trabalho e do sistema produtivo provocadas pela globalização.

Nesse cenário, o universo dos trabalhadores que demandam proteção jurídica é cada vez mais amplo, não podendo o Direito do Trabalho ignorar a existência do trabalho autônomo, dos contratos atípicos flexíveis e de outras formas de labor diversas da relação de emprego. É certo que a maior parte dos trabalhadores de hoje, de alguma forma, presta serviços de modo dependente.

A proteção jurídica do trabalho é um direito fundamental de todo o trabalhador na busca pela dignidade da pessoa humana que trabalha em sentido amplo, sendo que a todos deve ser assegurado um núcleo mínimo de direitos trabalhistas.

O mercado moderno necessita contar com formas flexíveis de trabalho, capazes de atender a demanda produtiva de forma dinâmica. Por outro lado, a flexibilidade do trabalho não pode ser acompanhada de precarização das condições de vida do trabalhador, que deve contar sempre com um mínimo de segurança.

O direito europeu, no estudo da problemática da compatibilização da necessidade de condições flexíveis de trabalho com a segurança do trabalhador desenvolveu a teoria da flexicurity que busca a harmonização justamente de tais conceitos antagônicos.

A presente tese apresentará os contornos de um modelo nacional de flexicurity capaz de modernizar o Direito do Trabalho pátrio de modo a expandir seu objeto para o maior número possível de trabalhadores, oferecendo regulamentação legal para formas flexíveis de trabalho que não a relação de emprego clássica, tendo como contrapartida medidas de segurança e empregabilidade para os trabalhadores, a quem será assegurado sempre um núcleo mínimo de direitos trabalhistas e a assistência nos períodos de transição.

Palavras Chave: Crise do Direito do Trabalho - Expansão do Direito do Trabalho - Flexibilização - Direito do Trabalho e Direitos Fundamentais - flexicurity 


\begin{abstract}
Traditional Labor Law, based on the protection of the classic employee, is in crisis. Among the factors responsible for the crisis it is worth to single out the labor market and production system transformations caused by the globalization.

In this scenario, the universe of workers who are in need of legal protection is becoming wider. Labor Law cannot ignore the existence of self-employment, flexible atypical work contracts and other forms of work distinct of the traditional employment relationship. Currently, most workers, even when self-employed, are dependent on capitalists.

Legal protection of all work forms is a fundamental right of every worker. Labor Law is essential for human dignity and a minimum set of core work rights must be ensured in all forms of labor contracts and arrangements.

The modern labor market demands flexible forms of work to enable a dynamic supply to the production needs. On the other hand, work flexibility cannot worsen the work conditions. Even in flexible markets, workers need a minimum of safety and security. European Law, concerned with the search for a balance between flexibility and security developed the flexicurity theory that tries to overcome such tensions between these antagonistic perspectives, with labor market flexibility on the one hand and social security on the other hand even if these concepts seems contradictory.

This thesis presents a national model of flexicurity able to modernize the country`s Labor Law expanding its applicability to all workers and not only formal employees. The model offers a legal regulation to flexible work forms, with security measures for all workers ensuring a minimum set of fundamental work rights and assistance on the periods between jobs.
\end{abstract}

Key Words: Labor Law Crisis - Expansion of Labor Law - Flexibilization of Labor Law Labor Law and Fundamental Rights - flexicurity 


\section{RIASSUNTO}

Il Diritto del lavoro tradizionale, improntato alla protezione del lavoratore subordinato fordista, è in crisi. Tra i fattori che ha provocato tale crisi meritano una particolare sottolineatura la trasformazione del mercato del lavoro e del sistema produttivo provocata dalla globalizzazione.

In questo scenario, l'insieme dei lavoratori che chiedono protezione giuridica è sempre più ampio, infatti il Diritto del lavoro non può ignorare l'esistenza del lavoro autonomo, dei contratti di lavoro atipici e delle altre forme di collaborazione lavorativa diverse dal lavoro subordinato. Sebbene sia certo che la maggior parte dei lavoratori, oggi, svolgono il loro lavoro in virtù di un contratto di lavoro subordinato.

La protezione giuridica del lavoro è un diritto fondamentale di tutti i lavoratori, funzionale ad assicurare la dignità della persona prima che del lavoratore, e pertanto a tutti i lavoratori, a prescindere dalla forma contrattuale adottata, devono essere riconosciuti dei diritti essenziali.

Il sistema produttivo moderno richiede sempre più forme di lavoro flessibili, capaci di soddisfare la dinamica domanda del mercato. D'altro lato, la flessibilità non può trasformarsi in precarizzazione delle condizioni del lavoratore, al quale non possono comunque essere sottratti i suoi diritti essenziali fra cui quello a svolgere il suo lavoro in un ambiente sicuro.

Il Diritto dell'Unione europea, proprio con riferimento ai concetti di flessibilità e sicurezza, ha coniato la teoria della flexicuirity, che si prefigge lo scopo di armonizzare tale concetti potenzialmente contrastanti.

Questo scritto illustrerà le linee essenziali di un modello nazionale di flexicurity capace di modernizzare il Diritto del lavoro brasiliano ed estenderlo al maggior numero di lavoratori possibile, proponendosi di disciplinare anche le forme di lavoro flessibili, cercando da una lato di creare le conzioni per assicurare un alto tasso di occupazione e dall'altro garantire la sicurezza ed un nucleo di diritti essenziali per il lavoratore, nonchè l'assitenza nei periodi di inoccupazione.

Espressioni chiave: Crisi del Diritto del lavoro - Estensione del Diritto del lavoro - Flessibilizzazione - Diritto del lavoro e Diritti fondamentali - flexicurity 


\section{INTRODUÇÃO}

A presente tese tem como título "Do protecionismo do empregado à proteção do trabalhador: desafios da flexicurity". O escopo do texto é demonstrar que o Direito do Trabalho clássico, fundado na proteção do empregado caracterizado principalmente pela subordinação jurídica, é insuficiente para regular a contento o moderno mundo do trabalho, sendo necessária a expansão do objeto do direito laboral para todo o ser humano que trabalha. Ademais, a expansão em análise deve se dar de tal modo a manter o equilíbrio das relações entre capital e trabalho, evitando-se distorções e má aplicação do direito, pelo que se faz necessária a adaptação dos novos paradigmas com parâmetros claros e seguros. Sustenta-se que essas adaptações devem envolver medidas de flexibilidade aos tomadores de serviço e segurança aos trabalhadores, com intervenções estatais de medidas de bem-estar-social discutidas por meio da participação de todos os atores sociais, em um cenário de promoção da chamada flexicurity.

A tese parte da premissa de que o Direito do Trabalho é essencial para a promoção da dignidade do ser humano. Considerando-se, portanto, que o ser humano persegue sempre a melhoria de sua condição pessoal, a conclusão do silogismo é de que o Direito do Trabalho deve almejar tornar-se o mais amplo possível. Ou seja, a busca deve ser sempre pelo incremento do Direito do Trabalho e nunca pelo seu retrocesso, ainda que se façam necessárias adaptações que o mantenham atualizado.

Ocorre, no entanto, que as relações jurídicas não são unilaterais. O reconhecimento de direitos sempre implica contrapartidas de uma ou mais partes, com custos e obrigações. $\mathrm{O}$ ordenamento jurídico deve prezar pelo equilíbrio em suas relações, com observância de seus valores e princípios fundamentais.

O Direito do Trabalho surgiu há pouco mais de duzentos anos como forma de proteção do trabalhador em face do capital, visto que reconhecidamente era o trabalhador hipossuficiente na relação jurídica, não possuindo poder de barganha. De tal modo, inexistindo o Direito do Trabalho, as relações com o Capital restariam relegadas às regras econômicas da oferta e da procura, com o trabalho considerado unicamente como fator de custo produtivo, culminando com a redução dos trabalhadores à miserabilidade. 
Deve-se ressaltar, no entanto, que a ciência do direito em geral, da qual não está excluído o Direito do Trabalho, é dinâmica e deve se adaptar à realidade social que procura regular, sob pena de se tornar obsoleta e até mesmo inócua. Como dito, o Direito do Trabalho não se deve render a pressões que impliquem retrocesso, o que não quer dizer que não deva se adaptar às necessidades modernas.

São indiscutíveis as profundas alterações sócio-econômicas e jurídico-políticas ocorridas nos últimos anos, especialmente após a Segunda Guerra Mundial, com fenômenos como a massificação produtiva, globalização econômica, revolução nos sistemas de transporte, comunicações e informações, bem como o crescimento exponencial do setor de serviços em detrimento de áreas clássicas da atividade econômica como o comércio e a indústria. Inegável, ainda, que tais transformações tenham impacto significativo na esfera de atuação do Direito do Trabalho.

A presente tese pretende demonstrar que o Direito do Trabalho clássico está em crise. Iniciar-se-á o texto com a análise dessa questão, destacando-se a crise econômica, a crise dos empregos, em sentido sócio-econômico e finalmente a crise jurídica propriamente dita, relativa ao elemento central do Direito do Trabalho que é a figura do empregado clássico, fundada em rígido grau de subordinação jurídica.

As alterações sócio-econômicas mencionadas acima têm por consequência a insuficiência do Direito do Trabalho clássico como instrumento de garantia de dignidade do ser humano que trabalha, sobretudo quando depende dos frutos desse trabalho para sua subsistência. O cenário sócio-econômico atual não prescinde do trabalho humano. Tampouco acredita-se que o trabalho deixará de ser o mais importante elemento do sistema produtivo e da própria condição humana enquanto partícipe do mundo "economicamente ativo". No entanto, as formas de utilização do trabalho humano são cada vez mais diversas e atípicas sob o ponto de vista jurídico, sem que a ciência juslaboral acompanhe a contento as implicações de tais mudanças.

Com efeito, quando do surgimento do Direito do Trabalho, a prestação de serviços subordinada (além de onerosa, pessoal e habitual) era a única a necessitar de proteção jurídica, por englobar a totalidade dos trabalhadores em condições de hipossuficiência nas relações com os tomadores de serviços. A relação empregado-empregador enquadrava satisfatoriamente o 
"mundo do trabalho". Toda a evolução do Direito do Trabalho desde então se deu em face das necessidades do empregado, limitando-se a essa categoria a proteção do ordenamento jurídico.

Ocorre que, embora ainda corresponda a uma parte significativa dos trabalhadores, o número dos que se enquadram como empregados no sentido jurídico do termo, tal qual descrito nos artigos $2^{\circ}$ e $3^{\circ}$ da Consolidação das Leis do Trabalho, já não abrange a totalidade daqueles que necessitam de proteção jurídica para atuarem de forma equilibrada nas relações entre capital e trabalho.

É de vital importância que o Direito do Trabalho passe a atentar para a situação decorrente da diversificação das relações jurídicas no âmbito do trabalho, com multiplicidade de formas contratuais envolvidas entre os que prestam algum tipo de serviço e os empresários que os contratam para o desenvolvimento de suas atividades produtivas.

Como se demonstrará, a doutrina justrabalhista já identifica há anos que o sistema de proteção jurídico-trabalhista voltado unicamente para o empregado, considerando esse como o único trabalhador hipossuficiente é inadequado para regular o universo das relações de trabalho modernas, acabando por deixar relevante parcela dos obreiros desabrigados de qualquer proteção jurídica.

É certo, portanto, que as novas relações de trabalho apresentam configurações muito mais complexas do que a dicotomia clássica de trabalho subordinado e trabalho autônomo. Há, nos tempos atuais, diversos graus de subordinação e formas de prestação de serviços onde o trabalhador, embora não seja empregado em sentido estrito, ou ainda que o seja, esteja enquadrado em modalidade contratual atípica, permanece em estado de hipossuficiência e necessita de proteção jurídica para a garantia da dignidade humana. Assim, o novo Direito do Trabalho não irá perder seu foco de proteção ao hipossuficiente, característica ressaltada por Cesarino Junior em obra clássica ${ }^{1}$, mas deverá adaptar-se para o reconhecimento das novas

\footnotetext{
${ }^{1}$ Destacava o autor que "não somente já observamos que toda a atividade social do Estado não faz objeto do Direito Social, como também observaremos que, na generalidade dos casos, o fim imediato do Estado não foi beneficiar aos indivíduos auto-suficientes, mas sim aos economicamente fracos, que chamamos de hipossuficientes. CESARINO JUNIOR, Antônio Ferreira. Direito Social Brasileiro. $4^{\mathrm{a}}$ ed., Rio de Janeiro: Freitas Bastos, 1957, v.1, pág. 40.
} 
categorias que possam, em determinado momento da relação entre capital e trabalho se encontrar em estado de necessidade de proteção jurídica.

De tal modo, a primeira parte da presente tese pretende demonstrar de modo detalhado a crise do Direito do Trabalho e suas relações com as constantes crises econômicas e a chamada crise do Emprego, decorrente das alterações do sistema produtivo e da forma de prestação de serviços.

O segundo ponto de análise do texto diz respeito ao Direito do Trabalho como integrante do universo dos Direitos Fundamentais. Em estreito relacionamento com o exposto nos tópicos anteriores, pretende-se demonstrar que o Direito do Trabalho é elemento central na garantia da existência digna de toda pessoa que trabalha, constituindo um conjunto de direitos fundamentais do ser humano e que como tal deve ser aplicado e desenvolvido de forma a atingir sua máxima eficácia, nas dimensões objetivas e subjetivas, abarcando todos os que trabalham e não somente os empregados em sentido estrito.

A caracterização do Direito do Trabalho como Direito Fundamental é de crucial importância para o desenvolvimento da tese, permitindo a utilização do arcabouço científico da Teoria Geral dos Direitos Fundamentais para fundamentar a expansão do objeto do Direito do Trabalho a figuras outras que não a do empregado clássico.

Demonstrada a inserção do Direito do Trabalho na esfera dos Direitos Fundamentais, faz-se necessária uma análise, ainda que breve, da estruturação teórica de tal campo jurídico, de modo a permitir-se a transferência de tais institutos para o objeto de aplicação da tese. Com efeito, não há como se verificar as consequências do enquadramento do Direito do Trabalho em tal esfera sem que se enfrente, ainda que de modo superficial, a questão da teoria geral dos direitos fundamentais em seu contexto dentro da teoria da Constituição. No mesmo aspecto, indispensável a análise da questão da interpretação da Constituição e dos Direitos Fundamentais, bem como a relativa à aplicabilidade de tais institutos jurídicos em uma concepção de estado democrático de direito que se funda na dignidade da pessoa humana e nos valores sociais do trabalho e da livre iniciativa.

Evidente, assim, que o texto em desenvolvimento não pretende esmiuçar o tema referente aos Direitos Fundamentais, sob pena de se desviar de seu objeto de modo incontornável. No entanto, é essencial para a compreensão da tese proposta e sua 
fundamentação jurídica que se faça uma breve análise da Teoria Geral dos Direitos Fundamentais aplicada ao Direito do Trabalho.

Dentro do contexto do Direito do Trabalho e dos Direitos Fundamentais, é de rigor, ainda, ao menos um breve estudo referente ao conceito de Trabalho Decente e seu desenvolvimento e estímulo pela Organização Internacional do Trabalho, inclusive no que diz respeito à sua recomendação de número 198.

As delimitações referentes ao Trabalho Decente permitem, ainda sob o contexto dos Direitos Fundamentais, sustentar a expansão do objeto do Direito do Trabalho para além da figura do empregado, garantindo um mínimo de condições civilizatórias a todos aqueles que dependem dos frutos de seu trabalho para a sobrevivência, independentemente da modalidade de contratação.

Ainda no âmbito dos Direitos Fundamentais, após a análise das implicações teóricas gerais, faz-se necessário estudar a figura do Direito do Trabalho brasileiro em face do ordenamento Constitucional pátrio. Com efeito, a configuração do Direito Constitucional nacional, em especial o positivado no texto de 1988, permite fundamentar a expansão do objeto do Direito do Trabalho em figuras como a garantia de direitos dos trabalhadores (e não dos empregados), além dos princípios de valorização do trabalho e livre iniciativa e a busca pela dignidade da pessoa humana.

O terceiro aspecto que pretende ser analisado pela tese diz respeito às formas de enfrentamento da crise, tanto a jurídica quanto a econômica já adotadas ou teorizadas. Verificar-se-á, de acordo com os resultados obtidos em outros ordenamentos jurídicos, a adequação de suas respostas ao objeto da tese em questão que é a expansão do objeto do Direito do Trabalho com segurança.

Nesse sentido, essencial a análise da figura da flexibilização em seus diversos aspectos e os resultados alcançados com as figuras já adotadas no Brasil e em outros países. Com efeito, a flexibilização é bandeira frequentemente adotada pelos empresários como elemento indispensável para a superação da crise econômica e modernização das relações entre capital e trabalho. De igual modo, a flexibilização é repudiada por entidades sindicais dos trabalhadores e alguns estudiosos da ciência juslaboral, sob o argumento de que implicaria sempre em 
precarização de direitos trabalhistas, em prejuízo da parte mais fraca da relação entre capital e trabalho que é, evidentemente, o trabalhador.

A tese busca demonstrar que a flexibilização não precisa ocorrer necessariamente em detrimento do trabalhador. Flexibilizar não é sinônimo de eliminar direitos, tampouco de desregulamentar as relações de trabalho. O termo flexibilizar deve ser tomado como forma de modernizar e de adaptar os institutos jurídicos às necessidades e realidades do mercado, o que não implica e nem deve implicar redução de garantias.

De fato, a flexibilização, quando corretamente entendida e aplicada, oferece uma alternativa para a solução da crise, tanto econômica quanto jurídica e não é incompatível com a ideia de expansão do Direito do Trabalho. A flexibilização, como defendido por conceituados doutrinadores que serão estudados ao longo da tese, não deve ser encarada como um elemento de destruição do direito do trabalho, mas interpretada e desenvolvida como ferramenta de adaptação do direito aos tempos atuais, adaptação essa que não deverá causar prejuízos aos trabalhadores, mas modernizar as relações jurídicas envolvidas no permanente conflito entre capital e trabalho.

O trabalho em tela parte do princípio de que as mudanças sócio-jurídico-econômicas são inevitáveis e que, portanto, não há como se inserir a realidade do mercado de trabalho moderno simplesmente nas categorias empregado e não-empregado, sob pena de se consagrar situações artificiais como as diuturnamente encontradas na Justiça do Trabalho nacional em pedidos de reconhecimento de vínculo de emprego dos mais diversos tipos de profissionais, incluindo aqueles que prestam serviços por meio de pessoa-jurídica.

Desse modo, a flexibilização consubstanciada em diversificação da tipologia contratual, distribuição de horário e jornada de trabalho e maior ou menor rigidez de contratação e dispensa não deve causar ojeriza ao estudioso da ciência juslaboral, que deve analisar tais mudanças também sob a ótica do trabalhador, com maiores possibilidades de serem inseridos na economia formal e de serem protegidos pelo Direito do Trabalho em sentido amplo como defendido na presente tese.

O texto examina, então, as experiências de flexibilização trabalhista no direito pátrio e comparado, em especial o italiano e europeu, com análise das medidas tomadas, da multiplicidade de tipologias contratuais e os resultados práticos alcançados. 
Em seguida é destacado papel da flexicurity ou "flexisegurança", figura moderna no campo sócio-jurídico-econômico, com origem na realidade dinamarquesa e expansão posterior para outros integrantes da União Europeia e aplicação paulatina em outros países. O instituto em questão é de grande relevância para a tese defendida, eis que procura compatibilizar os conceitos aparentemente antagônicos de flexibilidade e segurança nas relações de trabalho.

Far-se-á uma análise da figura da flexicurity, sua origem, evolução e aplicabilidade. Em seguida procurar-se-á verificar a viabilidade de aplicação da experiência para a realidade brasileira, com as necessárias adaptações. Por fim, a tese defenderá a possibilidade de expansão do Direito do Trabalho de modo compatível com o enfrentamento da crise jurídicoeconômica das relações de trabalho por meio da aplicação de um sistema de flexicurity específico para o ordenamento jurídico pátrio.

O quarto ponto da tese tratará da expansão propriamente dita do objeto do Direito do Trabalho de modo seguro, por meio da flexicurity. Fundamentado nos pontos discutidos anteriormente, o capítulo pretende demonstrar que toda a forma de trabalho humano possui características comuns e que todo o trabalhador que em algum momento esteja em situação de inferioridade contratual em relação ao capital tomador de serviços merece proteção jurídica.

Delimitadas as características comuns do trabalho humano dependente de proteção, o texto passa a indicar o núcleo comum de direitos mínimos que devem ser estendidos a todos os trabalhadores, independentemente da forma de contratação. Em seguida, demonstrar-se-á que a expansão de tal núcleo de direitos deve impactar em uma mudança de paradigma do Direito do Trabalho, passando da proteção do empregado para a proteção do trabalhador, medida essa necessária para a adaptação das relações entre capital e trabalho.

Por fim, a tese defendida pretende demonstrar que a transição da proteção do empregado para a proteção do trabalhador pode e deve se dar com segurança e que essa proteção pode ser alcançada pelos meios combinados da flexibilização para o tomador de serviços e segurança para o trabalhador, norteados por medidas inseridas em um contexto de estado de bem-estar-social.

. O termo segurança, nesse contexto, implica segurança jurídica para trabalhadores e empresários que contarão com um regramento jurídico específico para as relações de trabalho em sentido amplo, sem que necessitem recorrer a distorções de figuras jurídicas já existentes, 
tanto para tentar enquadrar como relação de emprego algo que de fato não o é, como em sentido contrário. Do mesmo modo, a segurança também pode ser entendida no contexto da flexicurity como meio de defesa da empregabilidade e de direitos do trabalhador em sentido amplo em face da maior flexibilidade requerida pelos empresários na forma de contratação.

A contribuição original que se pretende fazer para a ciência jurídica brasileira é a apresentação de um modelo nacional de flexicurity que implique expansão do objeto do Direito do Trabalho, com ampliação da proteção jurídica aos trabalhadores em sentido lato, sem olvidar das necessárias adaptações do mercado de trabalho em face da crise econômica e da consequente crise jurídica do Direito do Trabalho.

A intenção do texto é, assim, tratar da expansão do objeto do Direito do Trabalho, a transição da proteção do empregado à proteção do trabalhador, identificando os elementos que tornam necessária tal mudança e apontando formas para que o Novo Direito do Trabalho possa ser implementado com garantia da segurança e equilíbrio nas relações entre Capital e Trabalho. A tese apresentada busca contribuir na sugestão de novos paradigmas para o Direito do Trabalho, sem, contudo, ter a pretensão de esgotar o tema, que engloba a ciência juslaboral como um todo, mas analisando experiências já implementadas em outros países e seus resultados, bem como indicando as mais modernas tendências e possibilidades de adaptação do Direito do Trabalho ao novo cenário global nos aspectos sócio-político-econômicos, em especial por meio da chamada flexicurity. Desse modo, procurou-se a elaboração de um texto panorâmico, como indicado por Umberto $\mathrm{Eco}^{2}$, demonstrando-se os diversos posicionamentos da doutrina nacional e estrangeira, além de considerações quanto a experiências legislativas, quando existentes, em cada assunto, sempre acompanhados da opinião pessoal do autor.

\footnotetext{
${ }^{2}$ ECO, Umberto. Como se Faz uma Tese. $19^{a}$ ed., São Paulo: Perspectiva, 2004, pág. 35.
} 


\section{A CRISE DO DIREITO DO TRABALHO}

A presente tese, ao sugerir a expansão do objeto do Direito do Trabalho como possível solução para a busca da efetividade do direito social e adaptação da ciência jurídica ao moderno cenário sócio-econômico, parte do princípio de que o Direito do Trabalho tradicional está em crise. É imperativo, portanto, que referida crise seja identificada e analisada.

Constitui tarefa delicada para o estudioso do direito, assim como para qualquer cientista em seu ramo de pesquisa, a argumentação de que o objeto primordial de suas pesquisas está em grave crise. No entanto, é dever do pesquisador o reconhecimento dos problemas que afetam seu objeto de estudo e a proposição de soluções e adaptações para a evolução da ciência, jurídica ou não.

O ponto de interesse para o presente estudo é a crise do Direito do Trabalho. Em linhas gerais, a problemática em tela é de que o Direito do Trabalho tradicional, considerado como o sistema de regras e princípios que regulam a relação de emprego, ou melhor dizendo, que regulam as relações de trabalho subordinado, não é mais suficiente para oferecer regulamentação jurídica adequada a todas as relações de trabalho que demandam a intervenção do direito.

Como recorda Otávio Pinto e Silva "o que se percebe a cada dia na sociedade contemporânea é a necessidade de diversificação das relações jurídicas entre os sujeitos que prestam serviços (trabalhadores) e os que deles necessitam para o desenvolvimento de seus negócios (empresários). Em outras palavras: é necessário ampliar os 'vínculos de atributividade' entre capital e trabalho".

Irany Ferrari já alertava em palestra proferida há mais de dez anos que o Direito do Trabalho visto como ordenamento jurídico destinado a dar proteção ao hipossuficiente econômico subordinado, sob vínculo de emprego, é insuficiente para enfrentar a realidade moderna, ressaltando que todo tipo de trabalho deve ter alguma forma de proteção. ${ }^{4}$

\footnotetext{
${ }^{3}$ SILVA, Otávio Pinto e. Subordinação, Autonomia e Parassubordinação nas Relações de Trabalho. São Paulo: LTR, 2004, pág. 76 (versão digital).

${ }^{4}$ FERRARI, Irany. "Reforma Trabalhista". in PRADO, Ney, (coords.). Reforma Trabalhista - Direito do Trabalho ou Direito ao Trabalho. São Paulo: LTR, 2001, pág. 261.
} 
Não se pretende negar a essência do Direito do Trabalho como ferramenta jurídica de proteção do trabalhador subordinado, o hipossuficiente nas relações entre capital e trabalho. No entanto, não se pode olvidar que no cenário sócio-político-econômico atual, o trabalho subordinado corresponde somente a uma fração, ainda que de vital importância, do universo compreendido pelo ser humano trabalhador.

Além disso, conforme a reflexão de Bruno Caruso, o Direito do trabalho clássico foi concebido para a uniformização de tratamento dos trabalhadores e não mais atende de forma plena às demandas que decorrem da individualização das necessidades dos trabalhadores. Com o desenvolvimento das relações econômico-produtivas, há, atualmente, mesmo nos contratos de trabalho subordinado, a necessidade de tratamento diferenciado que somente pode ser encontrada com um maior grau de liberdade contratual. A inderrogabilidade de todas as normas que regem o contrato de trabalho e a aplicação compulsória das normas coletivas não permitem o atendimento das peculiaridades de cada caso, já que buscam a equalização e a distribuição uniforme de bens ${ }^{5}$.

Se por um lado é necessária a padronização de um mínimo de direitos e garantias do trabalhador, por outro lado é certo que essas condições não podem ficar confinadas apenas ao contrato de emprego, ignorando a existência de diversas outras formas lícitas de trabalho.

Não tem o presente texto a pretensão de eliminar o direito do trabalho ou de apresentálo como elemento de entrave ao desenvolvimento econômico por majorar os custos da produção. Pelo contrário, a identificação da crise e a proposta de solução visa a melhoria da condição social do trabalhador e a expansão de modo sustentável e proporcional de direitos a

\footnotetext{
${ }^{5}$ Nas palavras do autor: "As regards the traditional labour contract the phenomenon has therefore made things more complicated, in that this new centrality of the individual introduces a new bargaining power on the supply side, even in formally subordinate labour relations, bringing to light a need for differentiation in individual treatment and well-being that only an individual contract can meet, given that the classical tools of labour market regulation in many European systems (laws that cannot be derogated from and collective contracts with a distributive function) were devised to achieve just the opposite, that is, equalisation and uniform distribution of material assets." CARUSO, Bruno. "The Future of Labour Law: Traditional Models of Social Protection and a New Constitution of Social Rights". in W.P. Centro Studi di Diritto Del Lavoro Europeo "Massimo D 'Antona, n ${ }^{\circ}$ 12, 2002, pág. 6. Disponível em http://www.lex.unict.it/eurolabor/ricerca/wp/int/caruso_n8-2002int.pdf (último acesso em 28/12/2012).
} 
todo aquele que depende do trabalho para a subsistência, independente da maneira como tal trabalho é prestado.

Assim, é primordial no trabalho de identificação da crise, que se afaste a figura da “culpa do direito do trabalho". Aponta o festejado jurista Oscar Ermida Uriarte que: "a incapacidade do sistema econômico de criar ou manter emprego tem levado seus cultores a 'culpar' o Direito do Trabalho, que seria um dos obstáculos à sua ação: talvez se pudessem gerar (péssimos) empregos, se não houvesse (tantos) mínimos trabalhistas: eliminemo-los”. Portanto, como alerta o autor, a crise jurídica não pode ser encarada sob o viés econômico somente, sob pena de se afastar o elemento civilizatório do Direito do Trabalho como forma de equilíbrio das relações entre o capital e o trabalho.

Como ressaltado por Luigi Mariucci, a solução para os problemas relacionados ao mercado de trabalho não está na destruição do sistema de salvaguardas que envolve o trabalho assalariado clássico, mas em uma revisão do sistema envolvendo as demais formas de prestação de trabalho pelo ser humano. ${ }^{7}$

Não é demais lembrar que o trabalho consiste em elemento chave do sistema capitalista. Sem trabalho não há capitalismo. No entanto, sob o ponto de vista econômico, trabalho é sinônimo de custo e a tendência natural do mercado é a busca pela produção com o menor dispêndio de recursos possível. Essa é, em linhas muitos gerais, a ótica econômica do trabalho.

Para o capitalista o Direito do Trabalho é sempre um elemento crítico, uma vez que eleva o custo da produção. Não é esse, no entanto, o elemento central da crise que se propõe analisar. Pelo contrário, a presente tese parte do pressuposto de que o Direito do Trabalho é o principal elemento civilizador das relações entre capital e trabalho e que, como tal, deve ser expandido, ao invés de mitigado ou extinto. Como destaca David Harvey, a questão social, decorrente da relação capital-trabalho, sempre cumpriu papel central nas chamadas crises

\footnotetext{
${ }^{6}$ URIARTE, Oscar Ermida. “A Flexibilização do Direito do Trabalho na Experiência Latino-Americana”. in Revista da Escola da Magistratura do Tribunal Regional do Trabalho da $2^{a}$ Região, ano I, $\mathrm{n}^{\mathrm{o}}$ 1, setembro/2006, págs 134/135.

${ }^{7}$ MARIUCCI, Luigi. "Changes in Employment and Labour Law”. in Recounciling Labour Flexibility with Social Cohesion - Facing the Chalenge, Trends in Social Cohesion, $\mathrm{n}^{\circ}$ 15, Council of Europe Publishing, 2005, pág. 242.
} 
econômicas, mas a verdade é, que nos tempos atuais, a força do capital tende a esmagar as demandas do trabalho e não o contrário, como alardeado pelos detentores do poder econômico. ${ }^{8}$

Em primeiro lugar, portanto, cabe destacar que a crise de que se ocupa o presente estudo não é a econômica por si só, mas a crise jurídica do Direito do Trabalho. A crise econômica, ou melhor, a sucessão de crises econômicas, é indiscutível e tomada como pressuposto. A crise do direito do trabalho é decorrente da problemática econômica e o presente texto busca identificar e apresentar soluções no campo jurídico para a questão envolvendo o direito e a necessidade de adaptação às necessidades do atual mercado de trabalho, sem nunca olvidar que a condição de proteção ao ser humano que trabalha deve nortear toda a atuação do juslaboralista.

A relação entre crise econômica, jurídica e atuação estatal pode ser verificada nas palavras de Tarso Genro, para quem: “A crise do Direito do Trabalho está no centro da crise do Estado, pois a sua origem radica-se na capacidade normativa do Estado e no seu caráter intervencionista. O que se designa como 'perda da centralidade do mundo do trabalho', porém, não é o fim do trabalho como categoria central da reprodução social capitalista, nem a perda da importância política do mundo do trabalho"

A crise do direito do trabalho clássico decorrente da questão econômica, portanto, é indubitável e se apresenta de diversas formas, diretas e indiretas. A primeira forma que pode ser destacada é a do desemprego. Mais do que reflexo de crise econômica, o desemprego é, também, como visto, consequência jurídica da inadequação da relação de emprego clássica para o atendimento das novas demandas do mercado.

O crescente corte de postos de trabalho, tendência identificada por exemplo, por Jeremy Rifkin, há mais de quinze anos ${ }^{10}$, constitui fato inegável, ainda que se questione as

\footnotetext{
${ }^{8}$ HARVEY, David. The Enigma of Capital and the Crisis of Capitalism. $2^{\mathrm{a}}$ ed., London, Proflie Books, 2011, pág. 66.

${ }^{9}$ GENRO, Tarso. "Um Futuro por Armar". in Revista Democracia e Mundo do Trabalho, novembro/1998, págs $62 / 63$.

${ }^{10}$ Segundo o autor: "Agora, pela primeira vez, o trabalho humano está sendo sistematicamente eliminado o processo de produção. Em menos de um século, o trabalho "em massa" no setor do mercado será provavelmente eliminado em praticamente todas as nações industrializadas do mundo". RIFKIN, Jeremy. O Fim dos Empregos.
} 
proporções e limitações temporais propostas pelo autor. Tal desemprego ocorre por uma séria de fatores, como já dito, dentre eles, e com grande importância, está o fato de que a manutenção de um empregado, no sentido jurídico estrito do termo, é por demais custosa e inadequada para as modernas necessidades empresariais.

A primeira reação ao constatado corte de pessoal, tratando de aspectos exclusivamente jurídicos, pode ser a de busca pelo fortalecimento ainda maior dos sistemas de proteção do trabalho subordinado, como a limitação da dispensa individual e coletiva. No entanto, ainda em termos exclusivamente jurídicos, verifica-se que esse corte de empregados muitas vezes é diluído de forma a descaracterizar a dispensa coletiva, ou mesmo negociado e autorizado por entidades sindicais, sem apresentar solução a longo prazo para o trabalhador que acaba dispensado da mesma forma, sob o manto de justificativas técnicas, econômicas e financeiras.

A dispensa do empregado acaba por se tornar inevitável a longo prazo. No entanto, permanece a necessidade do trabalho que sempre será elemento central do sistema capitalista de produção (e nesse ponto discordamos do supracitado Jeremy Rifkin). A crescente automação e reengenharia empresarial eliminam a necessidade de muitas formas de trabalho subordinado, mas o trabalho humano continua a ser essencial tanto no sistema produtivo, quanto no setor de serviços e no chamado terceiro setor. Há que se destacar, entretanto, que o trabalho utilizado para atender as novas necessidades decorrentes do processo de modernização não é mais exclusivamente subordinado. Pode-se afirmar, até mesmo, que em relevante parte das novas necessidades, em especial nos serviços e no terceiro setor, a tendência é de que o trabalho subordinado passe a ser a exceção. Nesse sentido a lição de Hugo Barretto Ghione de que as formas ditas atípicas de trabalho que antes constituíam apenas exceções, hoje em dia, desde os anos oitenta, constituem diretrizes do desenvolvimento da legislação trabalhista. ${ }^{11}$

$2^{\mathrm{a}}$ ed., São Paulo: M. Books do Brasil., 2004, pág. 3.

${ }^{11}$ Segundo o autor: "em los años ochenta la atención de los estudiosos del derecho del trabajo se centraba em las llamadas relaciones del trabajo atípicas, generando profunsa bibliografia y una apertura a la compresión de fenómenos que, si bien hasta el momento eran vistos como excepcionales, comenzaban a promover interrogantes sobre el rumbo de la regulación del trabajo". GHIONE, Hugo Barretto. "La Determinación de la relación de trabajo em la Recomendación 198 y el fin del discurso único de la subordinación jurídica”. in Revista 
Não se pode fugir da discussão e da realidade de que as concepções protetivas clássicas estão em crise. Segundo Nelson Mannrich, “as grandes transformações ocorridas no mercado de trabalho por conta de novas tecnologias da comunicação e informação colocam em xeque não apenas o protecionismo do Direito do Trabalho, como a dicotomia trabalho subordinado $\mathrm{x}$ trabalho autônomo. Vale a pena discutir saídas para uma reforma trabalhista que vem sendo adiada com prejuízo da competitividade das empresas. ${ }^{12,}$

Sustenta Ricardo Antunes que a crise do mundo do trabalho decorre da nova forma flexibilizada de acumulação do capital, citando como consequência da reformulação capitalista que: “'1) há uma crescente redução do proletariado fabril estável, que se desenvolveu na vigência do binômio taylorismo/fordismo e que vem diminuindo com a reestruturação, flexibilização e desconcentração do espaço físico produtivo, típico da fase do toyotismo. 2) há um enorme incremento do novo proletariado, do subproletariado fabril e de serviços, o que tem sido denominado mundialmente de trabalho precarizado. São os terceirizados, subcontratados, part-time, entre tantas outras formas assemelhadas, que se expandem em inúmeras partes do mundo." Prossegue, ainda, o autor, afirmando que "a classe trabalhadora fragmentou-se, heterogeneizou-se e complexificou-se ainda mais." 13

Segundo o Professor Colombiano Guillermo López Guerra: "as circunstâncias mundiais nos forçam, mesmo contra a nossa vontade, a admitir que as instituições trabalhistas atuais puderam ser resposta adequada a fatos pretéritos, mas que, na atual situação social, deixam muito a desejar, quando não são fator de perturbação do desenvolvimento dos povos". ${ }^{14}$

A realidade francesa é refletida nas palavras de Antoine Jeammaud que, embora relute em empregar a palavra crise, reconhece a insuficiência da atual ciência juslaboral. Escreve o Trabalhista: Direito e Processo, ano 7, nº 25: LTR, 2008.

${ }^{12}$ MANNRICH, Nelson. Autonomia, Parassubordinação e subordinação: os Diversos níveis de proteção do trabalhador e do Teletrabalhador. Disponível em http://www.mackenzie.br/fileadmin/Graduacao/ FDir/Artigos/nelson_manrich.pdf, pág. 1. (último acesso em 02/01/2013).

${ }^{13}$ ANTUNES, Ricardo. Adeus ao Trabalho - ensaio sobre as metamorfoses e a centralidade no mundo do trabalho. 15a ed.. São Paulo: Cortez, 2011, págs. 197/198.

${ }^{14}$ GUERRA, Guillermo López. "Garantismo e Flexibilidade na Legislação do Direito do Trabalho da América Latina. Direitos Trabalhistas e a Flexibilidade”. in PERONE, Gian Carlo; SCHIPANI, Sandro, (coords). Principios para um Código-Tipo de Direito do Trabalho para a América Latina. São Paulo: Ltr, 1996, pág. 152. 
professor francês que: "a mesma exigência conceptual - o que entendemos por 'crise'? - nos impede de corroborar o diagnóstico de uma crise do direito do trabalho. Entretanto, não faltariam motivos hoje de sermos tentados a aceitar tal diagnóstico. Pensamos na contestação de sua legitimidade, tanto quanto na queixa de uma "operacionalidade declinante" que atestariam notórios "disfuncionamentos": o direito do trabalho seria menos apto a permitir uma clara identificação das relações por ele regidas e também menos apto a apreender uma fragmentação cada vez mais freqüente do tempo do trabalho. Excetuando-se mesmo os fenômenos de desconhecimento de suas regras, ele teria perdido sua capacidade técnica de ordenar uma parte da realidade que ele pretende governar" ${ }^{\prime 15}$.

Luisa Galantino, ao tratar da realidade Italiana, destaca que o Direito do Trabalho atual acaba por sofrer contradições internas, protegendo alguns que dele não necessitam, como a figura de diretores empregados e deixando de lado trabalhadores débeis que se submetem a formas de contratação extremamente frágeis, fora da figura clássica da subordinação e da proteção juslaboral, sendo autônomos somente no campo formal. ${ }^{16}$

Massimo D`Antona, jurista italiano assassinado pelo grupo terrorista Brigada Rossa sob a alegação de que suas propostas de reforma do Direito do Trabalho eram lesivas à classe operária, ressaltava já em 1998 que os fundamentos tradicionais do campo juslaboral estavam em crise. Segundo o autor, o Direito do Trabalho, em especial o italiano, tinha quatro pilares básicos que não mais correspondiam à realidade, devendo passar necessariamente por uma profunda reestruturação, ou mesmo por demolição, sendo eles: (i) o Estado-nação; (ii) a grande fábrica; (iii) o pleno emprego; e (iv) a representação geral dos trabalhadores por meio do sindicato. ${ }^{17}$

15 JEAMMAUD, Antoine, "Direito do Trabalho em Transformação: Tentativa de Avaliação" (tradução de Joaquim Leonel de Rezende Alvim), in Revista da Faculdade de Direito da UFF, nº 1, 1998, pág. 09.

${ }^{16}$ No original: "[il diritto del lavoro] è venuto meno alla sua matrice tipica non essendo in grado di garantire alcuna tutela a chi oggi, pur ponendosi sul mercato in condizioni di estrema deboleza (anzi, proprio per questo), operi com una veste giuridica non riconducibile all area del lavoro subordinato tecnicamente inteso e, quindi, non rientri nel campo applicativo delle relative garanzie". GALANTINO, Luisa. Diritto del Lavoro. 17 ed., Torino: G. Giappichelli, 2010, pág. 20.

${ }^{17}$ No texto original sustenta o autor que: "l'identità del diritto del lavoro che conosciamo poggia su quattro pilastri, tutti architettonicamente pertinenti a quel periodo storico e a quel contesto, e tutti in via di profonda ristrutturazione, se non addirittura di demolizione. (...) il primo pilastro: lo Stato-nazione; (...) il secondo pilastro: 
É preciso o diagnóstico de D`Antona. O cenário sócio-político-econômico fértil para o desenvolvimento do Direito do Trabalho alcançou seu ápice nos momento de estouro produtivo, passando em seguida ao declínio. Identificada o historiador Eric Hobsbawm que o fundamento da chamada Era de Ouro, nos anos 50, "era a incomum combinação 'keynesiana' de crescimento econômico numa economia capitalista baseada no consumo de massa de uma força de trabalho plenamente empregada e cada vez mais bem paga e protegida. ${ }^{18}$ " A situação mudou totalmente com as sucessivas crises econômicas desde 1973, sendo que a reconstrução do sistema capitalista se deu em pilares diferenciados dos clássicos.

Com efeito, é perfeitamente aplicável à realidade pátria o diagnóstico efetuado pelo professor peninsular. A globalização abalou intensamente o dogma do Estado-nação com a fragilização de fronteiras, e o crescimento do comércio global, com práticas concorrenciais que impactam diretamente no Direito do Trabalho.

A "grande fábrica", marco da ciência juslaboral e indissociável da ideia correspondente ao modelo fordista de produção, embora ainda existente, já não é o paradigma do trabalho, diversificado e distribuído em especial no setor de serviços e empresas de menor porte.

A ocupação plena, ou o pleno emprego, há muito tornaram-se utopias, com crescentes índices de desemprego, agravados ainda mais pelas constantes crises financeiras.

Por fim, a representação sindical na esfera nacional sempre foi, e ainda o é, salvo algumas exceções, frágil e descompromissadas, não sendo legítima protetora dos interesses dos trabalhadores.

Em que pese o presente texto defender ser inevitável a crise decorrente das transformações produtivas e de já se ter demonstrado tal fato com fundamento em balizada doutrina, deve-se, por lealdade científica, reconhecer que há autores que sustentam inexistir crise do mundo do trabalho decorrente das transformações econômicas e que tal visão do modelo decorre somente do posicionamento capitalista ultraliberal. Nesse sentido, argumenta

la grande fabricca; (...) il terzo pilastro: la piena occupazione; Il quarto pilastro: la rappresentanza generale del lavoro attraverso il sindacato." D`ANTONA, Massimo. "Diritto del Lavoro di Fine Secolo: una crisi d’identità". in Rivista Giuridica Del Lavoro, ano 49, n. 1, Roma: Ediesse, 1998, págs. 312/316.

${ }^{18}$ HOBSBAWM, Eric. A era dos Extremos - O breve século XX - 1914-1991. $2^{\mathrm{a}}$ ed., São Paulo: Companhia das Letras, 2010, pág. 276. 
Solange Barbosa de Castro Coura que: "determinados a romper as barreiras e valendo-se de sua hegemonia, os defensores do capitalismo ultraliberal formularam diagnósticos de fim dos empregos e de que o desemprego que se alastrou pelos países ocidentais na década de 1980 possuía natureza estrutural, ou seja, seria uma decorrência lógica e inevitável do sistema e que o Direito do Trabalho deveria, simplesmente, se adequar a tais realidades. ${ }^{19,}$

Com o devido respeito aos que defendem a inexistência de crise do Direito do Trabalho, parece ao autor da presente tese que tal corrente de pensamento confunde emprego com trabalho e Direito do Trabalho com Direito do Emprego. Com dito anteriormente, sustenta-se aqui que as relações de trabalho vão muito além dos limites da relação de emprego, não necessitando-se de grande esforço mental para essa conclusão, e de que a proteção do ser humano deve ser focada na atividade pessoal produtiva, o trabalho, e não necessariamente na forma como esse trabalho é prestado. Não há nada de ultraliberal na argumentação, visto que em momento algum se pretende eliminar direitos ou precarizar as relações de trabalho, mas pelo contrário, sustenta-se a necessidade da expansão protetiva ao trabalho que já está sendo prestado, sendo, novamente com a devida licença, limitada a alegação de que todo trabalho prestado de forma pessoal a outrem deva necessariamente ser considerado relação de emprego.

Os pilares do Direito do Trabalho, portanto, encontram-se minados por rachaduras graves. Partindo-se de premissas insuficientes, obviamente não se atingirão conclusões satisfatórias. A reforma nas estruturas básicas do campo juslaboral deve incorporar outras formas de trabalho além da relação de emprego.

A partir do momento em que o arcabouço jurídico trabalhista não comporta todas as relações jurídicas de trabalho e cada vez mais deixa à sua margem trabalhadores inseridos em outras categoria, ou seja, todos os não empregados em sentido clássico, é evidente que se está diante de uma crise do Direito do Trabalho.

Valorosa a lembrança de Cássio Mesquita Barros Junior de que: “quando o Direito do Trabalho começa a se consolidar como matéria de direito no século XX, o mundo do trabalho não se parece mais com o mundo em que o direito se inspirou. Se o plano que serviu de base ao direito do trabalho muda fundamentalmente, não pode mais esse direito ter influência sobre

\footnotetext{
${ }^{19}$ COURA, Solange Barbosa de Castro. "O Capitalismo Contemporâneo e suas Transformações - O Impacto da Terceirização Trabalhista”. in Revista LTr, ano 75, v. 12, 2011, pág. 1462.
} 
o mundo diferente, pois terá ocorrido o que na Teoria das Ciências se chama, comparativamente, de 'mudança de paradigma'."20

No mesmo sentido, aduz Thereza Christina Nahas que "é preciso se conscientizar que as relações de trabalho alteraram-se. Não se pode mais enxergar o trabalhador como o modelo que informou o nascimento do direito do trabalho no século XIX e fez do contrato subordinado a forma contratual mais negociada do século XX. Outras figuras contratuais, todas com o objetivo de prestar serviços, foram surgindo em razão da evolução que a sociedade passou, exigindo do trabalhador maior competência e qualificação. A entrada maciça das mulheres no mercado de trabalho e as mutações econômicas e sociais serviram de base para o surgimento de novos tipos contratuais, não se tornando mais possível ver no contrato de trabalho subordinado o único modelo a receber a tutela jurídica. As empresas passaram por transformações, obviamente motivadas por razões de ordem econômica e social, que desencadearam a necessidade de renovar o velho modelo e redesenhar a sua estrutura, a fim de que pudesse ter condições de sobreviver às concorrências do mercado e à abertura internacional." $" 21$

A lição de Domenico de Masi é no sentido de que não se nega a existência, ainda atual, de numerosa massa de trabalhadores manuais e operários, aqueles que fundamentaram a criação do direito do Trabalho clássico, mas que tal massa não possuem mais a força revolucionário de antes, tampouco guardam papel central no processo produtivo focado em mão-de-obra manual do Terceiro Mundo e força intelectual dos países desenvolvidos. ${ }^{22}$

${ }^{20}$ BARROS JUNIOR, Cássio Mesquita. “O Futuro do Direito do Trabalho”. Palestra proferida no $10^{\circ}$ Congresso Brasileiro de Direito do Trabalho em São Paulo em 16/04/2002, disponível em http://www.mesquitabarros.com.br/index.php?option=com_content\&view=article\&id=29:o-futuro-do-direito-dotrabalho\&catid=7:artigos\&Itemid=3\&lang=es

${ }^{21}$ NAHAS, Thereza Christina. "Considerações a Respeito da Relação de Trabalho: A Questão do Trabalho Semidependente". in Juris Síntese, nº 69, janeiro/fevereiro de 2007.

${ }^{22}$ Nas palavras do pensador italiano: "sarei pazzo se negassi che esiste ancora una massa numerosa di operai e manovali. Il fatto è che essi non sono più capaci de accollarsi problemi universali, non sono più una forza $<$ rivoluzionaria $>$, non sono più <centrali $>$ nella strategia di riscatto dallo sfruttamento, che ormai passa soprattutto attraverso la manodopera del Terzo Mundo e la mentedopera del Primo Mondo. DE MASI, Domenico. Ozio Creativo - Conversazione con Maria Serena Palieri, $3^{\mathrm{a}}$ ed., Milano: BUR Psicologia e Società, 2006, págs., 94/95. 
Como será demonstrado ao longo da presente tese, o trabalhador que deixa de ser empregado por força das circunstâncias e necessidades do mercado, perde a condição de sujeito de direito protegido pelas instituições do direito do trabalho clássico. Ao se reinserir no mercado por meio de outra figura, seja ela o trabalho autônomo, ou uma das formas flexíveis modernas, fato é que continua um ser humano que trabalha e como tal merece e necessita de proteção jurídica. Apenas com a expansão do objeto do direito do trabalho e a adequação do sistema jurídico às novas modalidades do mercado é que o trabalhador continuará a ser protegido em suas necessidades básicas e poderá exercer suas atividades e garantir seu sustento e de sua família com decência.

Leandro Krebs Gonçalves, ao discorrer sobre as questões e riscos envolvendo o futuro do Direito do Trabalho, identifica que "torna-se necessário, acima de tais riscos, dar vida a um novo Direito do Trabalho mais amplo, visto que não reconhecer essas formas atípicas de labor seria abandonar esses trabalhadores à própria sorte." 23

Poder-se-ia argumentar que a relação de trabalho é gênero do qual a relação de emprego é espécie e que desde a sua origem o direito do trabalho se ocupou dessa última categoria, sendo a ela voltados os princípios e todo o desenvolvimento da ciência justrabalhista. $\mathrm{O}$ argumento não é equivocado, se tomado isoladamente. No entanto, o que se verifica é que o direito do trabalho classicamente desenvolvido não é mais apto a desenvolver plenamente o seu escopo, o de proteção do trabalhador, assim entendido como o ser humano que trabalha.

A própria questão terminológica é indicativa da aqui estudada crise do direito do trabalho. Muito se debateu na doutrina a nomenclatura "Direito do Trabalho". A opção pela mesma certamente não se deu por antipatia a outras possibilidades levantadas como "Direito do Emprego", "Direito Social", ou "Direito Industrial", mas sim por entender-se que o então nascente ramo do direito deveria tutelar o trabalho como elemento objetivo e a pessoa do trabalhador como elemento subjetivo. No entanto, é certo que à época podia-se enquadrar no conceito de empregado todos os trabalhadores que dependiam de proteção jurídica específica em face do capital, fato que, como dito, não corresponde à realidade atual.

\footnotetext{
${ }^{23}$ GONÇALVES, Leandro Krebs. "Os Direitos Constitucionais do Trabalhador Autônomo". in Cadernos da Amatra IV, ano V, n 14 , novembro/2010, págs 50/51.
} 
Debruçando-se sobre a fixação histórica da nomenclatura do direito do trabalho e sua área de atuação, pode-se perceber que já se enfrentaram crises similares à atual, ao menos no que diz respeito aos sujeitos do direito laboral. Em obra clássica de 1975, Paulo Emílio Ribeiro de Vilhena, ao estudar elementos de direito comparado entre Brasil, França, Itália e Alemanha identificou que "a tendência de superar a distinção entre operários e empregados, através da formação de um conceito unitário de trabalhador (tomador de trabalho), deve ser vista, em primeiro plano, como uma tentativa de reavaliação da estruturação da classe trabalhadora. ${ }^{24 "} \mathrm{Na}$ ocasião a discussão também girava em torno do objeto do direito do trabalho, mas partia do princípio da necessária unificação do conceito de empregado. Deve ser destacado que ainda hoje existe no direito europeu diferenciações entre trabalhadores, como os "empregados", "operários" e "quadros" do direito italiano, sem que haja, no entanto, a exclusão de uma ou mais categoriais do "núcleo duro" de normas que compõe o direito do trabalho, assim entendido aquele que visa tutelar a pessoa do trabalhador.

Voltando à atualidade, como já demonstrado, vivencia-se uma nova crise e de tal monta que extrapola a questão terminológica. Não é possível superar a atual crise forçando o enquadramento das novas forças de trabalho nas regras específicas da relação de emprego. Há situações que demandam a prestação de serviços de forma diferenciada, flexibilizada, autônoma ou de outro tipo, sem que se possa regular tais serviços tratando-os como relação de emprego que não são. Entretanto, há que se ressaltar mais uma vez que os trabalhadores que se inserem nas tipologias contratuais modernas necessitam também de proteção do ordenamento e, no atual estado do direito do trabalho, acabam por ficar à margem do sistema jurídico trabalhista.

As propostas de flexibilização pura e simples, bem como de eliminação de direitos trabalhistas em nada contribui para a solução da crise, como se verá pormenorizadamente adiante no texto.

É falacioso o argumento que nega a crise do direito do trabalho ao afirmar que o empregado é o único tipo de trabalhador que demanda proteção jurídica específica. Mais uma

\footnotetext{
${ }^{24}$ VILHENA, Paulo Emílio Ribeiro de. Relação de Emprego: Estrutura Legal e Supostos. São Paulo: Saraiva, 1975, págs. 153/154.
} 
vez partindo-se de características terminológicas, a presunção com relação a um trabalhador autônomo, por exemplo, é de que esse é capaz de desenvolver suas atividades por sua conta e risco, estando em perfeito estado de negociar as cláusulas contratuais de trabalho com o tomador de serviços em paridade de condições. Não é preciso nem mesmo formação jurídica para se concluir que tal fato não corresponde à maioria dos trabalhadores hoje ditos autônomos.

O já citado jurista Luigi Mariucci identifica a crise em análise e incita a discussão a respeito de um velho e um novo direito do trabalho, na medida em que o autônomo em posição de desvantagem na relação jurídica também demanda proteção social como o pagamento de períodos de não-trabalho e benefícios para saúde, maternidade e velhice ${ }^{25}$.

O direito italiano já trata de parte da questão envolvendo o Direito do Trabalho para atividades autônomas e, em especial, as denominadas no direito italiano de parassubordinadas. Dentre os fatores que levaram o direito peninsular a adotar regras específicas para o trabalho em colaboração coordenada e continuativa (espécie de trabalho autônomo-parassubordinado), o professor Giuseppe Ferraro identifica parte da crise ora estudada apontando dentre as transformações do mercado a insuficiência da definição legal de trabalho subordinado, a problemática dos casos limítrofes e incompatibilidade entre a tutela do trabalho subordinado, apenas, e o mundo do trabalho em sentido lato ${ }^{26}$.

A própria Organização Internacional do Trabalho reconhece a importância das mudanças de paradigma envolvendo a necessária proteção do trabalhador, independente da existência de uma relação de emprego. Em 2006 foi editada a Recomendação no 198 da OIT "Relativa à Relação de Trabalho", tratando de aspectos do trabalho decente preocupando-se

\footnotetext{
${ }^{25}$ Nas palavras originais do citado professor: "In other words, the boundary between salaried employment and self-employment must be redefined. As far as self-employment among those in a week position is concerned, social protection and welfare measures must be introduced: income payments for periods without work, maternity benefits, health protection and pension contributions". MARIUCCI, Luigi. op. cit. pág. 244.

${ }^{26}$ No original identifica o professor, além das transformações do processo produtivo e necessidades empresariais: "uma diffusa insofferenza della definizione codicistica del lavoro subordinato che, oltre alle difficoltà applicative in casi limitrofi, finisce per rendere troppo drastica la diversità di tutele tra il lavoro dipendente e l'eterogeneo mondo del lavoro autônomo." FERRARO, Giuseppe. Tipologie di Lavoro Flessibile. Torino: G. Giappichelli, 2009, pág. 249.
} 
com a determinação da relação de trabalho e as formas de proteção do trabalhador, independente da existência de relação de emprego e de formas legislativas capazes de impedir o mascarar o reconhecimento da relação de trabalho.

As tendências observadas nas relações de trabalho dos países europeus apontam todas para o enfrentamento de uma crise do direito do trabalho. As reformas e estudos partem de pressupostos multidisciplinares, sendo de maior impacto a questão sócio-econômica. No entanto, como já visto no início do capítulo, os desdobramentos das alterações sócioeconômicas implicam na existência de um crise jurídico-positiva no que diz respeito ao cerne do direito do trabalho.

No cenário jurídico-político europeu recente, vem ganhando destaque a figura da flexicurity que será melhor analisada em capítulo apartado. No presente momento de identificação da crise do direito laboral clássico, cabe o destaque de que a flexicurity se ocupa da possibilidade em equalizar a crescente demanda mercadológica pela flexibilização do trabalho e das relações produtivas e a necessidade de proteção e segurança da classe trabalhadora. ${ }^{27}$

Assim, identificar a crise do direito do trabalho não quer dizer, como já ressaltado, buscar a eliminação de direitos. Tampouco se pretende enquadrar os direitos do trabalhadores simplesmente dentre as leis econômicas da oferta e da procura, retornando-se ao estado de miserabilidade jurídica do trabalho que se verificava no período anterior ao surgimento do direito do trabalho. Por outro lado, se é certo que o trabalho não pode ser tratado como mercadoria e não pode ser sujeitado às leis econômicas sob pena do esmagamento do

\footnotetext{
${ }^{27}$ Nesse sentido as palavras dos pesquisadores holandeses Ton Wilthagen e Frank Tros "on the one hand there is a strong demand for further flexibilisation of labour markets, employment and the work organisation. At same time, an equally strong demand exists for providing security to employees - especially vulnerable groups - and for preserving social cohesion in our societies. WILTHAGEN, Ton; e TROS, Frank. "The Concept of flexicurity: A New Approach to Regulating Employment and Labour Markets". in flexicurity: Conceptual Issues and Political Implementation in Europe, TRANSFER, European Review of Labour and Research, vol. 10, nº.2., 2004, pág. 166.

Em tradução livre: "por um lado há forte demanda pela contínua flexibilização dos mercados de trabalho, emprego e organização do trabalho. Ao mesmo tempo, uma igualmente forte demanda existe para que seja provida segurança aos empregados - especialmente grupos vulneráveis, e pela preservação da coesão social em nossas sociedades."
} 
trabalhador, não menos certo é que o conjunto de regras e princípios que rege as relações de trabalho deve ser adaptado para enfrentar novas realidades sob pena de se tornar obsoleto e incapaz de atingir o escopo de proteção da pessoa que trabalha. Enquadra-se na hipótese a clássica citação de Georges Ripert de que "quando o direito ignora a realidade, a realidade se vinga ignorando o direito".

Nesse diapasão, argumenta João Bosco Leopoldino da Fonseca que “deveríamos então perguntar se as experiências que vivemos hoje são as mesmas que deram origem à Consolidação das Leis do Trabalho em 1943. Verificaremos desde logo que o Direito que tentamos aplicar hoje não se ajusta à realidade vivida, ou que a realidade em constante evolução rejeita o Direito já criado. O Direito é criado pelo homem para reger sua vida de acordo com a realidade histórica em que vive, e com pretensão também de sobrevivência. Há certamente uma diferença palmar entre o Direito hoje existente nos livros e o Direito vivo, ou o Direito que se pretende criar. ${ }^{28, "}$

Não obstante a necessidade de se enfrentar a nova realidade, é importante lembrar a lição de Jorge Luiz Souto Maior ao alertar que "está na moda dizer que os direitos trabalhistas constituem um desestímulo ao emprego" e que "o fator econômico, que muitas vezes não passa de mero argumento que nunca se comprova, nega vigência ao Direito Social, e isso é feito como se nada estivesse ocorrendo. Se essa razão valesse, se a necessidade econômica valesse, todos os outros direitos estariam correndo risco de eficácia" ${ }^{29}$. Concorda-se em parte com o exposto pelo eminente professor. No entanto, parece ser possível, e esse é o escopo da presente tese, a conciliação entre as necessidades econômicas atuais e a evolução do direito do trabalho, sem que isso implique em eliminação da proteção jurídica a ser direcionada ao trabalhador.

A busca pela solução da crise juslaboral deve ter em mente a auspiciosa lição do Ministro José Luciano de Castilho Pereira para quem: "por tudo que ficou dito, com os pés fincados no presente, carregando toda a herança de um passado que ainda não acabou, vejo

\footnotetext{
${ }^{28}$ FONSECA, João Bosco Leopoldino. "Globalização e Direito do Trabalho". in Revista do TST, vol. 65, n 1, outubro/dezembro/1999, pág. 210.

${ }^{29}$ SOUTO MAIOR, Jorge Luiz. "Valores Fundamentais do Direito Social". Cadernos da Amatra IV, ano III, nº 7 , abril/junho/2008, pág. 34 .
} 
para o futuro, uma crescente importância para o Direito do Trabalho, enquanto assegurador da dignidade humana de quem trabalha, nas muitas e variadas formas de exercício da atividade do homem, nesta multifacetada realidade do mundo do trabalho, em permanente transformação. ${ }^{30}$

Em face do incontestável cenário de crise do Direito do Trabalho, dois caminhos são possíveis para a busca da solução. O primeiro deles é o proposto por Lorena Vasconcelos Porto de expansão do critério de subordinação para que se considerem empregados mais trabalhadores. Afirma a autora que "Para cumprir esse papel, é fundamental expandir o campo de incidência das normas trabalhistas, para que elas possam abranger, o máximo possível, os trabalhadores hipossuficientes, que delas necessitam. Nesse sentido, é essencial a ampliação da noção de subordinação, elemento qualificador por excelência da relação de emprego. A restrição desse conceito - que vem sendo operada nos últimos tempos, ao contrário, viola frontalmente os mandamentos das Constituições sociais, como a brasileira, pois restringe o âmbito de incidência de um instrumento primordial para $\mathrm{o}$ alcance das finalidades constitucionais: o direito do trabalho ${ }^{31}$ ".

O outro caminho possível é o defendido na presente tese de expansão do objeto do Direito do Trabalho por meio de uma mudança de paradigma. Nesse aspecto, é preciso o Direito do Trabalho passe a se preocupar com outras categorias que não o empregado em sentido clássico. Defender esse caminho é procurar alterar a realidade atual, onde o trabalho subordinado, nas palavras da autora citada acima, "representa a 'chave de acesso' aos direitos e garantias trabalhistas, os quais, em regra, são assegurados em sua plenitude apenas aos empregados $32 \%$.

Em síntese do exposto no presente capítulo, pode-se destacar que o Direito do Trabalho está em crise. A crise não é ideológica e tampouco exclusivamente econômica. Trata-se, sem dúvida de crise jurídica, no sentido de que o Direito do Trabalho clássico é insuficiente para

\footnotetext{
${ }^{30}$ PEREIRA, José Luciano de Castilho. "Futuro do Direito e do Processo do Trabalho no Brasil". Conferência proferida no XX Encontro Anual dos Magistrados da Justiça do Trabalho da $2^{\text {a }}$ Região em 31/10/2004,disponível em www3.tst.jus.br/ArtigosJuridicos/gmlcp/futurododireitoedoprocessodotrabalho.pdf

31 PORTO, Lorena Vasconcelos. "A Necessidade de uma Releitura Universalizante do Conceito de Subordinação". in Juris Síntese, n 73 , setembro/outubro de 2008. (versão digital).

${ }^{32}$ PORTO, Lorena Vasconcelos. op. cit.
} 
regular as novas formas de relação de trabalho utilizadas pelo mercado para atendimento de necessidades modernas. Não há como se ignorar a existência de formas de relação de trabalho diversas do trabalho subordinado em sentido clássico, tampouco pretender-se que todo tipo de trabalhador e de relação de trabalho devam ser enquadrados nos limites da relação de emprego. Evidente, ainda, que também os trabalhadores "não empregados" necessitam, em grande parte, da proteção do Direito do Trabalho e essa proteção não será adequada com a distorção e tentativa de enquadramento artificial de modos diferenciados de trabalho na relação de emprego. A evolução do Direito do Trabalho proposta é expandir-se a ponto de atender também a formas diversas de trabalho que não o subordinado em sentido clássico. Identificada a crise nos moldes supracitados, procurar-se-á ao longo da presente tese a formulação de soluções capazes de tornar o moderno Direito do Trabalho capaz de atender a demanda de proteção de todos os trabalhadores que possam ser considerados hipossuficientes no sentido de necessitarem de um núcleo jurídico-normativo capaz de garantir a dignidade da pessoa que depende do próprio trabalho para sobreviver. 


\section{DIREITO DO TRABALHO E DIREITOS FUNDAMENTAIS}

Como destacado na introdução da presente tese, faz-se necessária para a compreensão do Direito do Trabalho sob o manto dos Direitos Fundamentais, a apresentação, ainda que de forma breve e simplificada de uma Teoria Geral dos Direitos Fundamentais, bem como de sua positivação no Direito Pátrio, principalmente na vigente Constituição da República de 1988. Evidentemente que não se desenvolverá uma tese a respeito da Teoria Geral dos Direitos Fundamentais, mas apenas se demonstrarão os conceitos básicos, de modo a tornar possível o enquadramento do Direito do Trabalho na citada Teoria do Direitos Fundamentais.

Como ensina Paulo Bonavides: "toda interpretação dos direitos fundamentais vinculase, de necessidade, a uma teoria dos direitos fundamentais; esta por sua vez a uma teoria da Constituição, e ambas - a teoria dos direitos fundamentais e a teoria da Constituição - a uma indeclinável concepção do Estado, da Constituição e da cidadania, consubstanciando uma ideologia sem a qual aquelas doutrinas, em seu sentido político, jurídico e social mais profundo, ficariam de todo ininteligíveis. De tal concepção brota a contextura teórica que faz a legitimidade da Constituição e dos direitos fundamentais, traduzida numa tábua de valores, os valores da ordem democrática do Estado de Direito onde jaz a eficácia das regras constitucionais e repousa a estabilidade de princípios do ordenamento jurídico, regido por uma teoria material da Constituição." 33

A discussão a respeito de uma Teoria Geral de determinado instituto jurídico deve iniciar-se com sua conceituação e denominação. Assim, como ressalta Ingo Wolfgang Sarlet ${ }^{34}$, o próprio título do capítulo indica que o texto adota a denominação "Direitos Fundamentais", cabendo, no entanto, lembrar que diversas outras denominações foram e são utilizadas pela doutrina, como "Direitos Humanos" e "Direitos do Homem". A doutrina apresenta distinções entre essas denominações, ainda que se deva ressaltar o caráter principalmente didático de tal separação.

\footnotetext{
${ }^{33}$ BONAVIDES, Paulo. Curso de Direito Constitucional. 19ª ed., São Paulo: Malheiros, 2006, pág. 581.

${ }^{34}$ SARLET, Ingo Wolfgang. A Eficácia dos Direitos Fundamentais. 6 a ed., Porto Alegre: Livraria do Advogado, 2006, pág, 33.
} 
Deve-se lembrar, ainda, que outras denominações para os direitos em análise foram sendo abandonadas ao longo do tempo pela doutrina constitucional por se apresentarem insuficientes para o enquadramento qualitativo e quantitativo daquilo que se toma nessa tese como Direitos Fundamentais. São expressões atualmente rechaçadas, dentre outras: "liberdades públicas", "liberdades fundamentais", "direitos individuais", "direitos naturais" e “direitos públicos subjetivos".

De acordo com o constitucionalista português José Canotilho: “As expressões direitos do homem e direitos fundamentais são freqüentemente utilizadas como sinônimas. Segundo a sua origem e significado poderíamos distingui-las da seguinte maneira: direitos do homem são direitos válidos para todos os povos em todos os tempos (dimensão jusnaturalistauniversalista); direitos fundamentais são os direitos do homem, jurídico-institucionalmente garantidos e limitados espacio-temporalmente. Os direitos do homem arrancariam da própria natureza humana e daí o seu caráter inviolável, intemporal e universal; os direitos fundamentais seriam os direitos objetivamente vigentes numa ordem jurídica concreta." ${ }^{35}$

Ingo Wolfgang Sarlet" ${ }^{36}$, por sua vez, faz a distinção entre "direitos do homem", que seriam os direitos naturais não, ou ainda não positivados, "direitos humanos", aqueles positivados na esfera do direito internacional e "direitos fundamentais", os direitos reconhecidos ou outorgados e protegidos pelo direito constitucional interno de cada Estado.

Paulo Bonavides ${ }^{37}$ ensina que as expressões "direitos do homem" e "direitos humanos" são mais utilizadas pelos autores anglo-americanos e latinos, ao passo que a doutrina constitucionalista alemã prefere a expressão "direitos fundamentais". Bonavides acata a denominação alemã e apresenta a definição de direitos fundamentais descrita por Konrad Hesse, como sendo aqueles que buscam "criar e manter os pressupostos elementares de uma vida na liberdade e na dignidade humana".

José Afonso da Silva utiliza uma combinação das principais denominações, adotando a expressão "direitos fundamentais do homem", que em sua lição "constitui a expressão mais adequada a este estudo, porque, além de referir-se a princípios que resumem a concepção do ${ }^{35}$ CANOTILHO, José Joaquim Gomes. Direito Constitucional e Teoria da Constituição. $7^{\mathrm{a}}$ ed, Coimbra: Almedina, 2003, pág. 393.

${ }^{36}$ SARLET, Ingo Wolfgang. op. cit., págs. 35/37.

${ }^{37}$ BONAVIDES, Paulo. op. cit., pág. 560. 
mundo e informam a ideologia política de cada ordenamento jurídico, é reservada para designar, no nível do direito positivo, aquelas prerrogativas e instituições que ele concretiza em garantias de uma convivência digna, livre e igual de todas as pessoas." $" 38$

Acolhe-se no presente texto a denominação Direitos Fundamentais para o tratamento dos direitos positivados que buscam os elementos essenciais da vida com dignidade humana, dotados das características da historicidade, universalidade, relatividade e irrenunciabilidade, dentre os quais defende-se o enquadramento do Direito do Trabalho em seu núcleo essencial no sentido lato.

A categoria de direitos em análise surgiu de um longo processo histórico de sedimentação. São aplicáveis a todos os homens independente de sua condição pessoal e nesse aspecto há uma diferenciação para o Direito do Trabalho que está vinculado à condição de pessoa que trabalha. Não são absolutos, já que os direitos de determinada pessoa encontram limites nos direitos fundamentais de outros, bem como em outros direitos fundamentais da coletividade, além de não serem passíveis de renúncia pelo destinatário.

Como já dito, não se pretende nesse tópico de uma tese voltada ao Direito do Trabalho esgotar o tema referente à evolução dos direitos fundamentais ao longo da história, o que demandaria um estudo específico e de dimensões bem menos modestas do que essa exposição. No entanto, ainda assim é necessária uma explicação, ainda que mínima para que se possa situar no presente a Teoria Geral dos Direitos Fundamentais e sua vinculação com o campo juslaboral.

Os marcos históricos de desenvolvimento dos fundamentais e do próprio constitucionalismo estão intimamente entrelaçados. Lembra Ingo Wolfganf Sarlet que só existe uma constituição em sentido material quando a norma apresenta organização do governo e elenca rol de direitos fundamentais. ${ }^{39}$

Apesar de existir posicionamento no sentido de que os Direitos Fundamentais são direitos naturais do homem, portanto preexistentes a qualquer positivação, pode-se apresentar como marco do reconhecimento de tais direitos a "Magna Carta" de 1215 assinada pelo Rei

\footnotetext{
${ }^{38}$ SILVA, José Afonso da. Curso de Direito Constitucional Positivo. 15ª ed., São Paulo: Malheiros, 1998, pág, 182.

${ }^{39}$ SARLET, Ingo Wolfgang, op. cit., págs. 69/71.
} 
João Sem Terra e pelos Bispos e Barões ingleses, servindo como ponto de referência para direitos como o "habeas corpus", o devido processo legal e a garantia da propriedade.

As declarações de direitos inglesas do século XVII, encampadas em grande parte pela declaração norte-americana de direitos de 1776 representam também marcos históricos na busca das garantias dos cidadãos, especialmente no tocante às liberdades públicas, caracterizadas por serem direitos do cidadão em face do Estado.

Deve-se destacar, no entanto, que dentro do processo histórico de evolução dos direitos fundamentais o maior marco é a Declaração dos Direitos do Homem e do Cidadão elaborada à luz da Revolução Francesa em 1789. Sobre o assunto ensina Paulo Bonavides ${ }^{40}$ : "Constatou-se então com irrecusável veracidade que as declarações antecedentes de ingleses e americanos podiam talvez ganhar em concretude, mas perdiam em espaço de abrangência, porquanto se dirigiam a uma camada social privilegiada (os barões feudais), quando muito a um povo ou a uma sociedade que se libertava politicamente, conforme era o caso das antigas colônias americanas, ao passo que a Declaração francesa de 1789 tinha por destinatário o gênero humano. Por isso mesmo, e pelas condições da época, foi a mais abstrata de todas as formulações solenes já feitas acerca da liberdade."

A partir de então, o movimento evolutivo dos direitos fundamentais apresentou certa estagnação até 1948, quando a Organização das Nações Unidas editou a Declaração Universal dos Direitos do Homem, procurando retomar o caráter universal da proteção dos Direitos Fundamentais e da dignidade da pessoa humana.

O processo evolutivo, como não poderia deixar de ser, permanece atualmente. Ganha destaque a luta por direitos de caráter universal e impessoal, como a paz mundial, direitos esses que se enquadrariam na categoria de Direitos Fundamentais de quarta dimensão, denominação será analisada mais adiante em tópico específico.

Dessa forma, é simples a verificação da característica da historicidade inerente aos Direitos Fundamentais. Trata-se de evolução longa, com a incorporação ao direito positivo de forma lenta, sendo relevante lembrar, por exemplo, que os Direitos Fundamentais de caráter social, dentre os quais, sob a ótica defendida nesta tese, se enquadra a grande categoria do Direito do Trabalho, somente passaram a integrar as cartas constitucionais no século XX.

\footnotetext{
${ }^{40}$ BONAVIDES, Paulo. op. cit., pág. 562.
} 
Em retorno ao assunto da subclassificação dos Direitos Fundamentais, merece destaque a clássica divisão de tais direitos "por gerações" ou "dimensões". Cabe lembrar que a primeira de tais denominações é afastada por autores como André Ramos Tavares ${ }^{41}$ que prefere a utilizar a expressão "dimensões dos direitos fundamentais". Tal se dá porque a palavra geração possuí significado fortemente cronológico, que não se coaduna com o escopo da classificação. Não se pode afirmar que os direitos relacionados à liberdade surgiram antes da igualdade, por exemplo. O que ocorreu foi a positivação dos direitos em momentos e situações distintas, daí a preferência do autor pela expressão dimensões dos direitos fundamentais.

Também a segunda denominação encontra críticos, como Emmanuel Tófilo Furtado, para quem "a palavra dimensão dá uma ideia de nível, vale dizer, de superioridade de uma dimensão em relação à outra, o que por si só arreda sua aplicação no estudo que ora se inicia, uma vez que não há que se falar em igualdade em qualquer regime onde não exista a liberdade, nem muito menos se falar em fraternidade onde não exista igualdade, não se podendo estabelecer uma hierarquia entre tais direitos humanos, o que por si só afasta a ideia de dimensão, que em sua essência é uma palavra que, enfatize-se, dá ideia de hierarquia, de posto, de posicionamento escalonado, onde algo ou alguém está em posição superior ou vantajosa em relação a outrem". ${ }^{42}$

Não se vislumbra qualquer prejuízo no uso de uma ou outra das denominações indicadas, levando-se em conta que ambas possuem finalidade meramente didática e que os óbices levantados pelos autores citados não interferem na essência da classificação. Assim, pode-se dizer que a separação em gerações, ou, como visto, dimensões, de Direitos Fundamentais enquadra-se na enumeração dos ideais da Revolução Francesa: liberdade, igualdade e fraternidade.

A primeira dimensão, ou geração, dos Direitos Fundamentais corresponderia, em tese, aos direitos individuais relacionados à liberdade, considerada em suas diversas facetas. $\mathrm{O}$ ponto de destaque dessa primeira dimensão são as chamadas liberdades públicas, direitos do cidadão em face do Estado, buscando controlar e limitar a atuação estatal na esfera de

\footnotetext{
${ }^{41}$ TAVARES, Andre Ramos. Curso de Direito Constitucional. 5 a ed., São Paulo: Saraiva, 2007, pág. .

${ }^{42}$ FURTADO, Emmanuel Teófilo. "Os Direitos Humanos de $5^{\mathrm{a}}$ Geração Enquanto Direitos à Paz e seus Reflexos no Mundo do Trabalho - Inércias, Avanços e Retrocessos na Constituição Federal e na Legislação". in Direitos Sociais na Constituição de 1988 - Uma análise crítica vinte anos depois, São Paulo: LTR, 2008, pág. 76.
} 
liberdade do indivíduo, respeitando-se o máximo possível de liberdade individual com o mínimo de interferência externa. A positivação de tais direitos surgiu em reação ao estado absolutista que definia o Antigo Regime deposto pela Revolução Francesa de 1789. Os direitos relativos a esta primeira dimensão significam, portanto, uma prestação negativa, um não-fazer do Estado em relação ao indivíduo.

A segunda geração, por sua vez, fundada na ideia de igualdade, busca prestações positivas por parte do Estado e não mais um não-fazer. É dever do Estado a eliminação da desigualdade por meio de prestações positivas correspondentes aos chamados direitos sociais dos cidadãos. Não se trata mais de direitos individuais, mas sim de prestações que garantam o justo convívio social. Direitos trabalhistas e previdenciários são exemplos marcantes de direitos de segunda dimensão, sendo marcos de sua introdução no Direito Constitucional moderno as Constituições Mexicana de 1917 e Alemã de 1919, a chamada Constituição de Weimar.

A terceira geração, ou dimensão, ainda seguindo a linha dos ideais da Revolução Francesa, corresponderia ao elemento fraternidade e representa a evolução dos Direitos Fundamentais para se alcançar e proteger aqueles direitos decorrentes da moderna sociedade de massas com os já conhecidos problemas decorrentes da industrialização e densa urbanização. É nessa dimensão que surgem os chamados direitos fundamentais difusos e coletivos, que possuem como titular não mais um indivíduo, seja em face do Estado exigindose prestações negativas ou em face da sociedade exigindo do Estado prestações positivas, mas sim um grupo, coletividade, muitas vezes até mesmo indeterminável. Insere-se nessa categoria, por exemplo, o direito a um meio ambiente equilibrado, inclusive no que diz respeito ao meio ambiente laboral.

Já fora da classificação clássica fundada nos ideais da Revolução Francesa, a doutrina constitucionalista moderna passou a identificar uma quarta dimensão, ou geração, de Direitos Fundamentais. Tal dimensão seria decorrente do inafastável fenômeno da globalização que acaba por minar o próprio conceito de soberania do Estado Nacional. Para Paulo Bonavides "são direitos da quarta geração o direito à democracia, o direito à informação e ao direito ao pluralismo. Deles depende a concretização da sociedade aberta do futuro, em sua dimensão de 
máxima universalidade, para a qual parece o mundo inclinar-se no plano de todas as relações de convivência" ${ }^{\prime 4}$.

Apresentadas as linhas gerais da Teoria Geral dos Direitos Fundamentais, para os fins da presente tese que defende a expansão do objeto do Direito do Trabalho por ser esse integrante da categoria dos Direitos Fundamentais, ao menos no que diz respeito ao Direito Constitucional do Trabalho, é importante tecer uma análise sobre o alcance da expressão "Direitos Fundamentais".

A questão gera controvérsias também e principalmente dentro do direito positivo nacional, uma vez que o texto da Constituição Federal, ao tratar dos limites ao poder de reforma, cláusulas pétreas previstas no artigo 60, refere-se aos direitos e garantias individuais, apenas. Entende-se nesse estudo que os direitos e garantias individuais não são apenas os constantes do artigo $5^{\circ}$.

Admite-se que não é pacífica na doutrina a conceituação dos direitos sociais, dentre os quais se enquadra o Direito Constitucional do Trabalho, como Direitos Fundamentais. Ensina Ingo Wolfgang Sarlet que: "o problema que se coloca é justamente a resistência em relação à aplicação desses elementos nucleares do regime jurídico-constitucional dos direitos fundamentais aos direitos sociais. Com efeito, tanto há quem diga que as normas de direitos sociais não se encontram abrangidas pelo disposto no artigo $5^{\circ}, \S 1^{\circ}$, da $\mathrm{CF}$, quanto quem sustente que os direitos sociais não operam como limites materiais ao poder de reforma constitucional, por não terem sido expressamente referidos no art. $60, \S 4^{\mathrm{o}}$, inciso IV, a CF." ${ }^{4}$

A Organização Internacional do Trabalho reconhece o Direito do Trabalho como direito fundamental no sentido de garantia da dignidade humana, no âmbito do trabalho decente, que será analisado em maiores detalhes em tópico próprio. Sob esse prisma, ao inserir o campo do trabalho entre os Direitos Humanos e comentar a Declaração sobre o Trabalho Decente, Clarissa Ribeiro Schinestsck afirma que "a concepção de direitos humanos como necessidades revela-se no âmbito da Declaração, na medida em que essa coloca o trabalho como uma necessidade de sobrevivência e de dignificação da pessoa humana. Somente o ${ }^{43}$ BONAVIDES, Paulo. op. cit, pág. 571.

${ }^{44}$ SARLET, Ingo Wolfgang. "Os Direitos Sociais como Direitos Fundamentais: Seu Conteúdo, Eficácia e Efetividade no Atual Marco Jurídico-Constitucional Brasileiro". in Cadernos da Amatra IV, ano IV, n 10 , janeiro/março/2009, pág. 18. 
trabalho com direitos mínimos é capaz de conferir dignidade à pessoa humana. A concepção de direitos humanos como necessidade está apoiada na noção segundo a qual, para satisfazer a necessidade de viver de forma digna, o homem reivindica a consagração de certos direitos que julga de fundamental importância para a sua humanização. ${ }^{45}$ "

Considerando-se fundamentais os direitos constitucionais que visam assegurar a dignidade da pessoa humana, é perfeitamente cabível a consideração dos direitos constitucionais trabalhistas em tal esfera. Com efeito, como ensina Arion Sayão Romita: "a função dos direitos fundamentais, em tal contexto, cresce de importância. O núcleo duro representado pela gama de direitos denominados fundamentais resiste ao embate dos novos acontecimentos de ordem econômica para reafirmar o império da necessidade de respeito à dignidade da pessoa humana. ${ }^{46 "}$ Nada mais razoável, portanto, que os direitos trabalhistas que asseguram a dignidade da pessoa humana enquanto trabalhador em face do capital recebam o status de direitos fundamentais.

Entende-se nessa tese que são fundamentais também os direitos sociais, sendo que os direitos trabalhistas previstos no artigo $7^{\circ}$ do texto constitucional, por exemplo, são direito sociais de caráter individual de cada trabalhador, portanto, direito fundamental e com limitação expressa ao poder de reforma como cláusula pétrea.

Para Valdete Souto Severo, a condição de Direitos Fundamentais Sociais decorre da própria elevação do valor-trabalho ao patamar de princípio fundamental do Estado Democrático de Direito. Segundo a autora: “as regras trabalhistas, sobretudo aquelas decorrentes das normas contidas no art. $7^{\circ}$ da Constituição Federal, se coadunam com a conceituação de direitos fundamentais sociais. É exatamente por isso que o valor-trabalho é elevado ao status de princípio fundamental do nosso Estado Democrático de Direito e precisa ser visto sob nova dimensão." ${ }^{47}$

\footnotetext{
${ }^{45}$ SCHINESTSCK, Clarisse Ribeiro. "A Declaração da OIT sobre Princípios e Direitos Fundamentais e a Promoção do Trabalho Decente". in BELTRAN, Ari Possidonio. (coord). União Europeia e o Direito do Trabalho. São Paulo: LTR, 2012, pág. 60.

${ }^{46}$ ROMITA, Arion Sayão. Direitos Fundamentais nas Relações de Trabalho. $4^{\mathrm{a}}$ ed., São Paulo: LTR, 2012, pág. 403.

${ }^{47}$ SEVERO, Valdete Souto. "O Mundo do Trabalho e a Flexibilização". in Direitos Sociais na Constituição de 1988 - Uma análise crítica vinte anos depois. São Paulo: LTR, 2008, pág. 441.
} 
Arnaldo Sussekind sustenta que "os direitos e garantias individuais elencados no art. $7^{\circ}$ da nossa Carta Magna, entre os quais os de natureza tipicamente trabalhista, constituem cláusulas pétreas, e consequentemente, não podem ser modificados por emendas constitucionais, em prejuízo dos trabalhadores (art. 60, $\S 4^{\circ}$, n. IV da Constituição)." ${ }^{48}$

Júlio Ricardo de Paula Amaral, ao destacar a questão dos Direitos Fundamentais inseridos em necessidade de garantias em relações pessoais de dependência, como a estatal e a empresarial, aduz que: "costuma-se afirmar, nesse contexto, que os direitos fundamentais também compõem estruturas básicas do Direito do Trabalho, levando-se em conta as características especiais de uma relação jurídica, em que não só a pessoa do trabalhador se encontra comprometida, mas atentando para o fato de que o trabalhador está inserido numa organização alheia e submetido a uma autoridade que, mesmo situada no âmbito privado, não deixa de ser um poder social com relevância jurídica." ${ }^{.9}$

Flávia Moreira Guimarães Pessoa relembra que "uma noção mais atualizada dos direitos fundamentais, porém, conduz à conclusão de que estes representam a constitucionalização dos direitos humanos que gozaram de alto grau de justificação ao longo da história e que são reconhecidos como condição para o exercício dos demais direitos". Prossegue a autora afirmando que os direitos trabalhistas previstos no artigo $7^{\circ}$ da Constituição Federal são direitos fundamentais por serem condição para a garantia da dignidade humana do trabalhador. ${ }^{50}$

\footnotetext{
${ }^{48}$ SUSSEKIND, Arnaldo. "Os Direitos Constitucionais Trabalhistas". in Direitos Sociais na Constituição de 1988 - Uma análise crítica vinte anos depois. São Paulo: LTR, 2008, pág. 45.

49 AMARAL, Júlio Ricardo de Paula. "Os Direitos Fundamentais e a Constitucionalização do Direito do Trabalho". in Direitos Sociais na Constituição de 1988 - Uma análise crítica vinte anos depois". São Paulo: LTR, 2008, pág. 260.

50 PESSOA, Flavia Moreira Guimarães. "A Globalização e Concretização dos Direitos Trabalhistas Fundamentais". in Revista Jurídica da Amatra da $17^{a}$ Região, ano V, nº 9, julho/2008, págs 121 e 129.
} 


\section{.III. DIREITO CONSTITUCIONAL DO TRABALHO - HERMENÊUTICA DE NORMAS CONSTITUCIONAIS TRABALHISTAS}

De acordo com o que foi tratado no capítulo anterior, a Carta Magna do país reconhece diversos direitos trabalhistas fundamentais, direitos esses que são defendidos na presente tese como aplicáveis a todas as categorias de trabalhadores que desenvolvem suas atividades em benefício da atividade econômica de outrem, independentemente da existência de vínculo de emprego. Ao se sustentar a interpretação ampliativa de tais direitos fundamentais, que será retomada de modo específico no capítulo concernente ao núcleo essencial de direitos de todos os trabalhadores, necessário se faz tecer algumas considerações sobre as peculiaridades da hermenêutica das normas constitucionais.

...Em primeiro lugar, é relevante a lição de José Joaquim Gomes Canotilho no sentido de que a interpretação da constituição deve sempre se pautar pelo princípio de que se trata da norma ápice de um sistema e que devem vincular as demais normas, nunca, ao contrário, serem interpretadas a fim de se moldarem ao ordenamento infra-constitucional. São de observância obrigatória pelo legislador e não programas que poderão ou não ser seguidos de acordo com as conveniências da situação. Justamente por comporem o ápice do sistema, apresentam-se mais abertas de forma a serem reguladas pela legislação inferior, mas sempre impondo as diretrizes a serem seguidas.

Nesse sentido, afirma o jurista português que "a interpretação das normas constitucionais apresenta, igualmente,particularidades relevantes relacionadas sobretudo com o carácter hierárquico supremo da constituição e com a função de determinante heterónoma dos preceitos constitucionais relativamente às normas colocadas num plano hierárquico inferior. Situadas no «vértice» da «pirâmide normativa», as normas constitucionais apresentam, em geral, uma maior abertura (e,consequentemente, uma menor densidade) que toma indispensável uma operação de concretização na qual se reconhece às entidades aplicadoras um «espaço de conformação» («liberdade de conformação», «discricionariedade») mais ou menos amplo. Por isso se afirma implicar o princípio da constitucionalidade a 
consideração das normas constitucionais como determinantes heterónomas das normas inferiores que as concretizem (leis, regulamentos, sentenças). ${ }^{51}$,

Manoel Gonçalves Ferreira Filho resume a situação de superioridade da Constituição e sua vinculação interpretativa da seguinte forma: “A Constituição Rígida é a lei suprema. É ela a base da ordem jurídica e a fonte de sua validade. Por isso, todas as leis a ela se subordinam e nenhuma pode contra ela dispor. A supremacia da Constituição decorre de sua origem, Provém ela de um poder que institui todos os outros e não é instituído por qualquer outro, de um poder que constitui todos os demais e é por isso denominado Poder Constituinte. (...) Por outro lado, da superioridade da Constituição resulta serem viciados todos os atos que com ela conflitam, ou seja, dela resulta a inconstitucionalidade dos atos que a contrariam." ${ }^{52}$

Ainda sobre a supremacia da Carta Magna, aduz José Afonso da Silva que isso "significa que a constituição se coloca no vértice do sistema jurídico do país, a que confere validade, e que todos os poderes estatais são legítimos na medida em que ela os reconheça e na proporção por ela distribuídos. É, enfim, a lei suprema do Estado, pois é nela que se encontram a própria estruturação deste e organização de seus órgãos; é nela que se acham as normas fundamentais de Estado, e só nisso se notará sua superioridade em relação às demais normas jurídicas" $" 53$.

O intérprete que se depara com uma norma constitucional não pode ignorar, ainda, o princípio da máxima efetividade. Pedro Lenza aduz que: “também chamado de princípio da eficiência ou da interpretação efetiva, o princípio da máxima efetividade das normas constitucionais deve ser entendido no sentido de a norma constitucional ter a mais ampla efetividade social." 54

Alexandre de Moraes, fundado nas lições de Canotilho e Jorge Miranda aponta que a constituição deve ser interpretada com observância "da máxima efetividade ou da eficiência: a uma norma constitucional deve ser atribuído o sentido que maior eficácia lhe conceda" e que

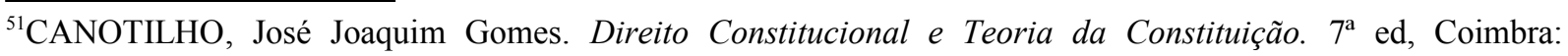
Almedina, 2003, pág. 210.

${ }^{52}$ FERREIRA FILHO, Manoel Gonçalves. Curso de Direito Constitucional. 24a ed., São Paulo: Saraiva, 1997, págs. 20/21.

${ }^{53}$ SILVA, José Afonso da. op. cit., pág. 47.

${ }^{54}$ LENZA, Pedro. Direito Constitucional Esquematizado. 12a ed., São Paulo: Saraiva, 2008, pág. 73. 
“deve ser fixada a premissa de que todas as normas constitucionais desempenham uma função útil no ordenamento, sendo vedada a interpretação que lhe suprima ou diminua a finalidade. ${ }^{55}$ " É relevante ressaltar, ainda, que as normas constitucionais apresentam-se em geral menos densas, ou mais abertas, como indicado na citação acima dos ensinamentos de Canotilho. Assim, ganha especial destaque na questão da hermenêutica constitucional o aspecto da força normativa dos princípios, bem como a relevância dos valores fundamentais.

O primeiro artigo do texto constitucional dispõe que: "A República Federativa do Brasil, formada pela união indissolúvel dos Estados e Municípios e do Distrito Federal, constitui-se em Estado Democrático de Direito e tem como fundamentos: I - a soberania; II - a cidadania III - a dignidade da pessoa humana; IV - os valores sociais do trabalho e da livre iniciativa; V - o pluralismo político".

Note-se, portanto, que já ao enumerar os fundamentos do próprio Estado, a Carta Magna nacional elenca o valor social do trabalho e a dignidade da pessoa humana, valores que coincidentemente embasam toda a construção da ciência juslaboral.

Importante a lembrança de que o Direito deve ser encarado como um sistema coerente. Partindo-se do princípio de que a Constituição é a norma ápice de tal sistema, é evidente que os valores que essa elege como fundamentais devem orientar todos os demais aspectos do ordenamento jurídico, inclusive as normas do próprio corpo constitucional, sob pena de se tornar o sistema incoerente.

Pode-se concluir, também especificamente com relação ao Direito do Trabalho, que a "dignidade da pessoa humana" e "o valor social do trabalho" possuem força normativa, tanto no aspecto positivo quanto no negativo. No positivo, observa-se que o legislador e o próprio constituinte, deverão produzir normas que tenham por escopo concretizar tais valores fundamentais. No sentido negativo, proíbe-se a criação de normas, inclusive constitucionais, que afrontem os valores que dão fundamento ao próprio sistema coroado pela Constituição.

Ademais, como dito, os fundamentos da "dignidade da pessoa humana" e "do valor social do trabalho" também possuem grande importância na hermenêutica constitucional. Com efeito, ao se interpretar normas constitucionais (e qualquer outra norma em face da inserção no sistema supramencionado), deve-se levar em consideração os valores fundamentais eleitos

\footnotetext{
${ }^{55}$ MORAES, Alexandre de. Direito Constitucional. $13^{\mathrm{a}}$ ed., São Paulo: Atlas, 2003, págs. 44/45.
} 
pelo soberano Poder Constituinte. Assim, quando, aplicadas as técnicas interpretativas, haja mais de uma possibilidade de sentido da norma, está o intérprete vinculado à hipótese que melhor se harmonize com os valores fundamentais. Frise-se novamente que não se trata de uma escolha do intérprete, os valores mencionados são fundamentais por se colocarem à base do sistema, não sendo possível sua supressão. Da mesma forma, não pode um arquiteto modificar um prédio suprimindo suas fundações, visto que evidentemente o prédio não será viável.

No mesmo sentido, leciona Airton Pereira Pinto que "com o princípio do respeito à dignidade da pessoa não há distorção em sentido e fim. Ele está em todo o sistema e nada pode existir sem a sua existência. Antes de adentrar em qualquer apreciação, seja no ato de legislar, executar, julgar, pesquisar e estudar o direito ou com base nele, o sujeito que age e pensa deve primar sua tarefa pela observação da existência dos princípios." ${ }^{56}$

${ }^{56}$ PINTO, Airton Pereira. Direito do Trabalho, Direitos Humanos Sociais e a Constituição Federal. São Paulo: LTR, 2006, pág. 86 . 


\section{O TRABALHO DECENTE}

A questão do Trabalho Decente é uma das principais bandeiras da Organização Internacional do Trabalho. Em solo brasileiro a OIT desenvolve a campanha em parceria com o Governo Federal desde 2003, quando da assinatura pelo então "Presidente da República, Luiz Inácio Lula da Silva, e pelo Diretor-Geral da OIT, Juan Somavia, do Memorando de Entendimento que prevê o estabelecimento de um Programa Especial de Cooperação Técnica para a Promoção de uma Agenda Nacional de Trabalho Decente, em consulta às organizações de empregadores e de trabalhadores. ${ }^{57}$,

Segundo definição da Agenda Nacional de Trabalho Decente de 2006: “entende-se por Trabalho Decente um trabalho adequadamente remunerado, exercido em condições de liberdade, equidade e segurança, capaz de garantir uma vida digna. ${ }^{58 "}$

A Organização Internacional do Trabalho define o tema da seguinte forma: "o Trabalho Decente é o ponto de convergência dos quatro objetivos estratégicos da OIT: o respeito aos direitos no trabalho (em especial aqueles definidos como fundamentais pela Declaração Relativa aos Direitos e Princípios Fundamentais no Trabalho e seu seguimento adotada em 1998: (i) liberdade sindical e reconhecimento efetivo do direito de negociação coletiva; (ii)eliminação de todas as formas de trabalho forçado; (iii) abolição efetiva do trabalho infantil; (iv) eliminação de todas as formas de discriminação em matéria de emprego e ocupação), a promoção do emprego produtivo e de qualidade, a extensão da proteção social e o fortalecimento do diálogo social. ${ }^{59}$,

De acordo com Sergio Pinto Martins: "propõe a OIT agenda de trabalho decente, consistente em promover o diálogo social, proteção social e criação de empregos. Esclarece que o trabalho não é mercadoria, pois não pode ser negociado pelo maior lucro ou pelo menor preço. Deve haver política de resultados nos Países, com distribuição de renda, fisscalização trabalhista, permitindo que as pessoas possam trabalhar com dignidade." Prossegue o autor

\footnotetext{
${ }^{57}$ Informação disponível em http://portal.mte.gov.br/antd.

${ }^{58}$ MINISTÉRIO DO TRABALHO E EMPREGO. Agenda Nacional de Trabalho Decente. Brasília: 2006, pág. 5.

Disponível em http://portal.mte.gov.br/data/files/8A7C816A2E7311D1012EFD9027785D9E/Agenda\%20 Nacional\%20do\%20Trabalho\%20Decente\%20em\%20Portugu\%C3\%AAs.pdf. (último acesso em 10/12/2012).

${ }^{59}$ Informação disponível em http://www.oitbrasil.org.br/content/o-que-e-trabalho-decente.
} 
afirmando que "a OIT considera as convenções que promovem trabalho decente: 1) 87, sobre liberdade sindical; 2) 98, sobre negociação coletiva; 3) 29, trabalho forçado; 4) 105, abolição do trabalho forçado; 5) 138, idade mínima para o trabalho; 6) 182, piores formas de trabalho infantil; 7) 100, igualdade de remuneração; 8) 111, não-discriminação"60.

É perfeitamente compatível com o intuito da presente tese o entendimento de Colin Fenwick, John Howe, Shelley Marshall e Ingrid Landau de que "o ponto chave é que o conceito de Trabalho Decente refere-se fundamentalmente ao reconhecimento de que 'todos aqueles que trabalham devem ter direitos". Assim, o exame de como atingir o Trabalho Decente necessita de uma abordagem fundada em direitos, ou, no caso, na questão de como melhor aplicar o Direito do Trabalho. ${ }^{61 "}$ A abordagem dos professores australianos, assim, e focada na necessidade de um mínimo de regulamentação e proteção de todos aqueles que trabalham, não sendo sequer possível falar em Trabalho Decente sem que a todos os trabalhadores seja assegurado um rol mínimo de direitos.

O Trabalho Decente não pode ser definido de forma mais sintética do que seu próprio nome. Assegurar condições decentes de trabalho implica atuações ligadas a uma série de fatores que vão desde o contexto econômico e social, limitação de jornada de trabalho, eliminação de formas odiosas de trabalho, medidas de saúde e segurança dos trabalhadores, garantia de tempo livre para a coexistência do trabalho, convivência familiar e lazer, além da própria estabilidade, senão no mesmo emprego, ao menos com a garantia de empregabilidade.

Ensina Clemente Massimiani que: "o objetivo de um trabalho decente para todos é considerado atualmente o 'coração do progresso social' e é intencionalmente definido pela OIT de maneira suficientemente 'aberta' por conta de sua vocação global. Apenas uma definição pouco rígida torna possível atingir os resultados desejáveis com profundidade,

${ }^{60}$ MARTINS, Sergio Pinto. "A OIT e a Globalização". in Juris Síntese, no 78, julho/agosto de 2009. (versão digital).

${ }^{61}$ FENWICK, Colin; HOWE, John, LANDAU, Ingrid, MARSHAL, Shelly. Labour and Labour-Related Laws in Micro and Small Enterprises: Innovative Regulatory Approaches. Genebra: OIT, 2007. Disponível em http://www.ilo.org/wcmsp5/groups/public/---ed_emp/---emp_ent/documents/publication/wcms_093618.pdf.

(último acesso em 28/12/2012). No original: "The key point is that the concept of Decent Work is fundamentally about the recognition that 'all those who work have rights at work'. Thus, an examination of how to achieve Decent Work necessitates a rights-based approach: in this case to the question of how best to apply labour laws". 
considerando os diversos contextos nacionais sob os pontos de vista econômico, social e cultural. (tradução livre)"'62

Não há dúvida, portanto, que a busca pelo trabalho decente deve ser uma das principais bandeiras da ciência jurídico-trabalhista moderna. A crise do Direito do Trabalho e as necessidades de adaptação e flexibilização não podem, como se defende nessa tese, se sobreporem ao bem maior a ser tutelado que é a dignidade do ser humano que trabalha. A proteção da viabilidade do mercado de trabalho não é um fim em si mesmo, mas meio de assegurar ao ser humano condições dignas de ganhar seu sustento por meio do trabalho decente.

\footnotetext{
${ }^{62}$ No original: "The objective of a decent job for all is considered today as the 'heart of social progress' and is intentionally designed by the ILO in a sufficiently 'open' manner because of its global vocation. In fact, only a loose definition could make it feasible to achieve the desired results in profoundly diverse national contexts from economic, social and cultural points of view." MASSIMIANI, Clemente. "flexicurity and Decent Work in Europe: can they co-exist?". in W.P. Centro Studi di Diritto Del Lavoro Europeo “Massimo D Antona, no 65, 2008, pág. 5. Disponível em http://www.lex.unict.it/eurolabor/ricerca/wp/int/massimiani_n65-2008int.pdf (último acesso em 30/12/2012).
} 


\section{FLEXIBILIZAÇÃO DO DIREITO DO TRABALHO}

Uma das principais queixas dos empresários em face da crise econômica e do custo produtivo diz respeito à inadequação do mercado de trabalho, decorrente, sob a ótica econômica, da rigidez e anacronismo do Direito do Trabalho. Surgiu então uma das principais bandeiras da política econômica neoliberal para combater os efeitos da crise econômica na esfera do trabalho, tal seja a da necessária flexibilização do Direito do Trabalho.

Para compreensão do fenômeno, é importante uma reflexão sobre as alterações do sistema produtivo. Ensina Georgenor de Sousa Franco Filho que: "no mundo, as grandes mudanças geralmente têm como sufixo a expressão ismos. No mundo do trabalho não é diferente, e iniciaram-se com o taylorismo (...), propugnando pela organização racional do trabalho, a fim de obter acréscimo significativo no nível operacional. Depois foi o fordismo de Henry Ford, (...) como modelo de produção em massa implantado no início de 1914, automatizando sua fábrica de veículos, mediante o uso de técnicas tayloristas, com padronização e simplificação. Seguiu-se o toyotismo (...), que se identifica como um modo de organização produtiva que ganhou projeção global com base no princípio Just in Time (produzir apenas o necessário). ${ }^{{ }^{63}}$

Alice Monteiro de Barros destaca que "a flexibilização no campo do trabalho, historicamente, tem sido uma reivindicação empresarial identificável com uma explícita solicitação de menores custos sociais e maior governabilidade do fator trabalho. Para a realização dessa reivindicação, reclama-se uma flexibilidade normativa, que poderá ser atingida sob o prisma legal, regulamentar e convencional, mas assegurando-se garantias mínimas ao empregado." ${ }^{\circ 4}$

$\mathrm{O}$ berço das ideias flexibilizadoras pode ser identificado no continente Europeu, local onde ganhou, ainda, maior aplicabilidade. Como recorda Amauri Mascaro Nascimento, em face das crescentes e reiteradas crises econômicas, "admitiu-se, na Europa, um direito do

\footnotetext{
${ }^{63}$ FRANCO FILHO, Georgenor de Souza. "O Trabalho Intelectual na Era da Informação - Pejotização - Blogs de Consultas e Contratos de Imagem”. in Revista LTr. ano 75, v. 7, 2011, pág. 836.

${ }^{64}$ BARROS, Alice Monteiro. Curso de Direito do Trabalho. São Paulo: LTR, 2005, págs. 80/81.
} 
trabalho de crise ou de emergência." ${ }^{65}$ Frise-se, apenas, que não se ignora que as condições de trabalho da América do Norte são extremamente flexíveis, contudo não se pode falar em movimento de flexibilização do Direito do Trabalho nos Estados Unidos, por exemplo, dado que nesse país o campo juslaboral sempre foi frágil e flexível, não tendo sofrido impactos jurídicos significativos com a crise.

Em primeiro lugar, não se pode confundir flexibilização com desregulamentação ou precarização de direitos. Flexibilizar não é sinônimo de eliminar. Como lembra Francisco Ribeiro, ao tratar da origem do termo "flexibilidade": "o sentido da palavra veio da mera observação do movimento da árvore que se dobra ao vento e volta à posição normal sem se quebrar ou danificar-se. Tal comportamento da árvore é indicado também para o homem em sociedade, no sentido de se adaptar às intempéries que a vida proporciona, possibilitando transporte as dificuldades sem sucumbir a elas. ${ }^{66 "}$

Gustavo Filipe Barbosa Garcia também distingue flexibilização de desregulamentação. Ensina o autor que "a chamada flexibilização pode ser entendida como forma de amenizar o rigor ou a rigidez de certas normas jurídicas, referentes, no caso, ao Direito do Trabalho. A desregulamentação, por sua vez, refere-se ao fenômeno de se suprimir determinadas normas jurídicas, principalmente estatais, pertinentes à regulação das relações de trabalho, passando os próprios atores sociais a estabelecer a regra aplicável. Nesse sentido, fala-se em desregulamentação negociada do Direito do Trabalho." ${ }^{97}$

Em consonância com o pensamento desenvolvido no presente estudo, de que a flexibilização, quando bem estruturada, pode atuar em beneficio do trabalhador com o enfrentamento da crise estrutural do Direito do Trabalho, o jurista italiano Antonio Vallebona defende a existência de uma crise do Direito do Trabalho por superação do conceito basilar de trabalho subordinado, enxergando na flexibilização uma possível solução por meio do regime da liberdade contratual assistida pelas entidades sindicais ${ }^{68}$.

\footnotetext{
${ }^{65}$ NASCIMENTO, Amauri Mascaro. Iniciação ao Direito do Trabalho. 27ª ed., São Paulo: LTR, 2001, pág. 63.

${ }^{66}$ RIBEIRO, Francisco. "Direito do Trabalho: flexibilização ou desregulamentação?”. in Revista Jurídica da Amatra da $17^{a}$ Região, ano IV, n ${ }^{\circ} 8$, maio/2007, pág 46.

${ }^{67}$ GARCIA, Gustavo Filipe Barbosa. Curso de Direito do Trabalho. São Paulo: Método, 2007, pág. 83.

${ }^{68}$ Lembra ainda o professor citado que: "Sia per ridurre il costo delle norme inderogabili in termini di certeza del diritto, che disincentiva l'allocazione delle imprese indispensabile per creare nuova ocupazione, sia per tutelare $\mathrm{i}$ veri deboli è necessario intervenire apertamente e direttamente sulla regolazione del singolo rapporto". Em
} 
Segundo Dagoberto Lima Godoy é preciso deixar de lado preconceitos em face do próprio termo flexibilização. Aduz o autor que: "trata-se de palavra que se tornou tabu, eis que tão pronto é pronunciada, radicaliza as posições e impede uma abordagem mais ampla da questão. Dessa forma, não somente bloqueia uma eventual reforma legislativa, quanto perde de vista as mudanças necessárias nas práticas e atitudes de empregadores e empregados, os atores principais do mundo do trabalho (embora muitas delas já estejam em curso no setor mais avançado das organizações empresariais). ${ }^{\circ 69}$

Arion Sayão Romita descreve a existência de basicamente três possíveis abordagens para o fenômeno da flexibilização. Na lição do citado professor: "a política de flexibilização trabalhista provoca o aparecimento de várias correntes de pensamento, que podem ser grosso modo classificadas: a) corrente favorável à flexibilização; b) corrente contrária; c) corrente moderada, ou intermediária. As duas primeiras, em posições extremas, não transigem na defesa dos pontos de vista que esposam, enquanto a última aceita os aspectos positivos de uma e de outra, na medida em que podem conciliar-se." ${ }^{70}$

Nesse sentido, não se pode ignorar o alerta de Amauri Mascaro Nascimento de que "a flexibilização do direito do trabalho faria dele mero apêndice da Economia e acabaria por transformar por completo a sua fisionomia originária. O direito do trabalho deixaria de ser uma defesa do homem contra a sua absorção pelo processo econômico para ser unicamente um conjunto de normas destinadas à realização do progresso econômico, mesmo que com sacrifícios insuportáveis dos trabalhadores. Estariam assim plenamente fundamentadas modificações estruturais do direito do trabalho que o afetariam profundamente em suas bases." 71

Flexibilizar não pode ser sinônimo de afastamento do Direito do Trabalho. Recorda Silvio Beltramelli Neto que "falar de flexibilização, tal como atualmente discutida no âmbito tradução livre: Seja para reduzir o custo das normas inderrogáveis em termos de certeza do direito, que desincentiva a alocação de recursos empresariais indipensáveis para a criação de novas ocupações, seja para tutelar os verdadeiramente necessitados, é necessário intervir aberta e diretamente sobre a relação jurídica individualmente considerada. VALlEBONA, Antonio. Breviario di Diritto del Lavoro. $6^{\mathrm{a}}$ ed., Torino: G. Giappichelli, 2010, págs. 38/39.

${ }^{69}$ GODOY, Dagoberto Lima. Flexisseguridade no Brasil. São Paulo: LTR, 2010, pág. 32.

${ }^{70}$ ROMITA, Arion Sayão. Flexigurança - A Reforma do Mercado de Trabalho. São Paulo: LTR, 2008, pág. 30

${ }^{71}$ NASCIMENTO, Amauri Mascaro. op. cit., pág. 64 
do Direito do Trabalho, significa pensar o arrefecimento (e, ao extremo, o total afastamento) da incidência da norma jurídica trabalhista de fonte heterônoma, ou seja, emanada do Estado, primordialmente por intermédio do Poder Legislativo. ${ }^{72}$ " O posicionamento é correto, desde que se atente para o termo "tal como atualmente discutida". Com efeito, o termo flexibilização, como mencionado, tem sido utilizado de modo diverso daquele que decorre do significado da palavra que, repita-se, não é sinônimo de enfraquecimento.

Não se concorda, ainda, com o posicionamento de Airton Rodrigues Moreira, para quem : "de qualquer forma, o Direito do Trabalho, a nosso ver, combate justamente as injustiças sociais, movidas por rescaldos cruéis do antagonismo econômico da luta de classes, em que sempre a classe economicamente forte leva vantagem, e que em alguns casos e momentos, não satisfeita com sua vantagem, agride direitos fundamentais e elementares do homem e do trabalhador, procurando solapar o que a ele restou (vide: teoria da flexibilização)" "73. Do mesmo modo como uma teoria ultraliberal de desregulamentação, o posicionamento radical de que flexibilizar significa agredir direitos fundamentais deve ser revisto.

Pertinente a lição de Sergio Pinto Martins de que "há necessidade, assim, de adaptação ou flexibilização, de modo a adaptar o Direito à realidade, e não o inverso. Flexibilização não é exatamente a revogação ou exclusão de direitos trabalhistas, mas a modificação de certos direitos mediante negociação coletiva, notadamente diante das crises econômicas." Prossegue o jurista afirmando que "distingue-se a flexibilização da precarização do trabalho. Nesta, há o trabalho incerto, instável e indefinido, a regulamentação insuficiente do trabalho, ou não existe qualquer regulamentação, ficando o trabalhador marginalizado. Na flexibilização deve haver a manutenção de um nível mínimo de legislação, com garantias básicas ao trabalhador e o restante seria estabelecido mediante negociação coletiva. Na flexibilização, há a adaptação a um novo contexto econômico."74

\footnotetext{
${ }^{72}$ BELTRAMELli NETO, Silvio. Limites da Flexibilização dos Direitos Trabalhistas. São Paulo: LTr, 2008, pág. 18.

${ }^{73}$ MOREIRA, Airton Rodrigues. "O Eterno Conflito Capital X Trabalho: Qual Modernização Necessária”. in Juris Síntese. $\mathrm{n}^{\circ}$ 88, março/abril de 2011.

${ }^{74}$ MARTINS, Sergio Pinto. Flexibilização das Condições de Trabalho. $4^{\mathrm{a}}$ ed., São Paulo: Atlas, 2009, págs. $14 / 15$.
} 
Sintética e esclarecedora a conclusão de Nelson Mannrich de que "a flexibilização apresenta-se com vários significados e vasta amplitude. O que se pretende é o ajuste das normas jurídicas à realidade econômica e assim contribuir para a solução dos problemas trabalhistas atuais." (negrito no original) ${ }^{75}$.

Com efeito, a flexibilização em suas variadas facetas não implica necessariamente, como visto, em um mal para o trabalhador. A adaptação às novas realidades sócio-econômicas pode, e deve, como sustentado nessa tese, repercutir na proteção mais acentuada de formas de trabalho existentes e até então à margem do Direito do Trabalho, sempre em vista da valorização do trabalho, da livre iniciativa e da dignidade do ser humano trabalhador.

No mesmo sentido a lição do Ministro Augusto César Leite de Carvalho para quem "ao menos no que toca às etapas da produção de bens e serviços ainda não transferidas à máquina, a lógica poderá ser a da flexibilização sem prejuízo das garantias mínimas asseguradas ao trabalho humano. Para tanto, é imperioso que não se faça tábula rasa do caráter geminado atribuído ao valor social do trabalho e ao valor - igualmente social - da livre iniciativa, pelo artigo $1^{\circ}$, IV, da nossa Carta Magna." ${ }^{76}$

Da mesma forma, defender a adaptação também não implica em enxergar na flexibilização a cura para todos os males. Há autores que associam a flexibilização com a proteção dos direitos fundamentais pela manutenção do emprego. Nesse sentido, afirma Antonio Cleto Gomes que "instrumentos de flexibilização mantém os direitos fundamentais de dignidade da pessoa humana, de segurança no trabalho, de saúde, além de manter o próprio emprego, bem maior da relação de trabalho. São medidas extraordinárias para uma realidade econômica difícil que, infelizmente, já chegou e não pode ser ignorada, realidade essa que repercute de forma decisiva em nossas empresas e no seio de nossos lares. ${ }^{77}$ " Em que pese a boa qualidade do artigo citado, não se concorda, como será demonstrado nesse capítulo, que a

75 MANNRICH, Nelson. "Limites da Flexibilização das Normas Trabalhistas". in Revista do Advogado. Associação dos Advogados de São Paulo no 54, dezembro de 1998, pág. 30.

${ }^{76}$ CARVAlHO, Augusto Cesar Leite de. Direito do Trabalho - Curso e Discurso. Aracaju: Evocati, 2011, pág. 116 (versão digital).

${ }^{77}$ GOMES, Antonio Cleto. "Das Negociações Coletivas de Trabalho - Flexibilização das Leis Trabalhistas Soluções Jurídicas Inteligentes para Tempos de Crise Econômica”. in Juris Síntese, nº 89, maio/junho de 2011. 
flexibilização isoladamente só atue na manutenção do nível de empregabilidade e muito menos na proteção da dignidade do trabalhador.

A flexibilização trabalhista somente ganha contornos de proteção do trabalhador quando os benefícios criados para os tomadores de serviço encontram contrapartida em aumento na proteção do trabalhador. Não há contradição nesses termos, desde que se entenda que trabalhador não é necessariamente o empregado típico.

Alerte-se que não se pode confundir flexibilização também com fraude trabalhista. $\mathrm{O}$ fenômeno que vem sendo chamado de "CLT Flex" nada tem de flexibilização, apesar do nome, sendo medida escusa utilizada para fraudar a legislação do contrato de trabalho com diminuição de custos ao fornecer utilidades de caráter salarial sob o falso argumento de que são indenizatórias. Destaca Adriana Vitorino ao tratar das novas formas de escamotear salário e reduzir custos que "um exemplo disso, é a modalidade de fraude apelidada de 'CLT Flex` ou 'CLT Cotas', na qual parte do salário do trabalhador é registrado na carteira de trabalho e a outra parte (normalmente a maior) é paga pelas chamadas 'cota-utilidades', as quais não são consideradas salários." 78

A própria reforma do mercado de trabalho ocorrida na Itália e que culminou com a adoção de diversas medidas de flexibilização, tinha como uma de suas propostas, infelizmente descartada ulteriormente por motivos político-econômicos, a criação de um estatuto não mais voltado aos empregados, mas aos trabalhadores. O projeto, segundo Giudice, Mariani e Izzo, do novo estatuto "dos trabalhadores" ou "dos trabalhos", preveria a superação da distinção entre trabalho autônomo e subordinado e a individualização de um núcleo duro de direitos trabalhistas fundamentais inderrogáveis, aplicáveis de modo variável e progressivo de acordo com o envolvimento do trabalhador na relação de trabalho com o tomador de serviços. ${ }^{79}$

\footnotetext{
${ }^{78}$ VITORINO, Adriana. “'CLT FLEX' - A Nova Modalidade de Fraude”. in Revista LTr, ano 76, v. 04, 2012, pág. 463.

${ }_{79}^{79}$ No original: "Lo statuto dei lavori prevede il superamento dell attuale distinzione delle attività lavorative in lavoro autônomo e lavoro subordinato e l'individuazione di < uno zoccolo duro e inderogabile di diritti fondamentali $>$ da applicare in modo graduale (a geometria variabile) e progressivo man mano che si intensifica il coinvolgimento del lavoratore nella relazione di lavoro". GIUDICE, Federico Del; MARIANI, Federico; IZZO, Fausto. Diritto Del Lavoro. Napoli: Simone, 2006, pág. 13.
} 
Giuseppe Santoro Passareli esclarece que em face das transformações da realidade industrial, o contrato de trabalho por tempo indeterminado não é mais a única forma de trabalho disponível, cedendo espaço para outras formas que, ainda que subordinadas, são temporárias. Ademais, prossegue o autor, muitos empreendedores satisfazem os interesses da produção com um trabalho autônomo ou descentralizado, justificando a necessidade da flexibilização das formas contratuais de trabalho ${ }^{80}$.

Alan Hyde identifica um movimento na realidade norte-america em direção à proliferação dos contratos de curta duração. Afirma que tal fato não implica, necessariamente, em um mal para o trabalhador, podendo ser a medida utilizada como forma de resposta flexível aos tempos de crise, acompanhada de incentivos para a estabilização dos trabalhadores quando superados os obstáculos de desemprego e dificuldades econômicas. Afirma o autor que "trabalhos curtos não necessitam ser (e de fato não são) inevitavelmente trabalhos ruins, sendo, no entanto, complicada sua relação com a distribuição de renda. Pode ser possível a uma sociedade que enfrente uma taxa de desemprego inaceitavelmente alta, mas mais compromissada com a distribuição de renda do que os EUA, proceder de tal modo: podese eliminar os impedimentos à criação de trabalhos de curta duração (permitindo agências de ajuda temporária, ou reduzindo os encargos para a formação de novos negócios). Ao mesmo tempo, é possível insistir em iniciativas políticas para encorajar a transição de contratos de curta duração para formas de trabalho mais estáveis." $" 81$

\footnotetext{
${ }^{80}$ Afirma o autor que: "in altri termi il rapporto di lavoro a tempo indeterminato, che dura per tutto l'arco della vita lavorativa, non costituisce più l'unica forma di lavoro dipendente ma cede il passo a forme di lavoro che, pur subordinate, sono temporanee. (...) In um crescente numero di casi l'imprenditore soddisfa le proprie esigenze di produzione utilizando forme di lavoro autônomo o decentrato.” SANTORO-PASSARELI, Giuseppe. "Competitività e flessibilità del rapporto di lavoro". in Rivista Italiana di Diritto del Lavoro, ano 28, v. 1, Milano: Giuffrè, 2009, págs. 203/204.

${ }^{81}$ No original: "Short jobs need not be (indeed are not) inevitably bad jobs, and their relationship to income distribution is complicated. It might well be possible for a society experiencing unacceptably high unemployment, but more committed to equality of distribution than the US, to proceed in the following way. It might eliminate impediments to the creation of short jobs (by permitting temporary help agencies, or reducing the burdens on the formation of new businesses). At the same time, it might insist on policy initiatives to encourage transition, from short jobs into more stable employment". HYDE, Alan. "Employee Organization and Employment Law in the Changing US Labor Market: America Moves Toward Shorter-Time Jobs". in W.P.
} 
Como exposto, a flexibilização surgiu como um dos modos de combater a crise econômica e consequentemente a crise do Direito do Trabalho. Há, no entanto, autores que sustentam que a crise do Direito do Trabalho é que decorre da flexibilização. Para essa corrente, a flexibilidade com a pretensão de enfrentar a crise econômica é que mina os pilares do Direito do Trabalho. Nesse diapasão afirma Rodrigo Goldschimidt a respeito que "enfim, nessa realidade é que foi forjada a ideia de flexibilidade, e com ela o Direito do Trabalho entrou em profunda crise, posto que, segundo a ideologia neoliberal, as normas trabalhistas são duras e inflexíveis, aumentando o custo da produção, razão pela qual devem ser flexibilizadas ou relativizadas, como forma de baratear a mão-de-obra e de viabilizar a competitividade das empresas no mercado local e global. ${ }^{~} 82$

Defende-se, assim, que é possível a flexibilização sem precarização das condições de trabalho. Para tal fim, no entanto, é imprescindível que o vocábulo "flexibilizar" seja entendido no sentido de "adaptar", de forma ampla. Essa adaptação é do Direito do Trabalho como um todo, de sua influência nas relações de trabalho, na própria estrutura da organização produtiva. Não deve, necessariamente, incidir sobre núcleo dos direitos garantidos aos empregados subordinados. Em outros termos, é possível flexibilizar o Direito do Trabalho sem alterar qualquer direito que já exista em relação a empregados clássicos, mas regulamentando outras formas de prestação de serviços já existentes, o que atenderia às exigências empresariais e ofereceria um mínimo de proteção ao trabalhador.

Jorge Luiz Souto Maior afirma que "um observador, que tenha como ramo de seu conhecimento o direito, e mais especificamente o direito do trabalho, não pode ter outro ponto de partida que não seja a justiça social. Nesta perspectiva parece inquestionável que a preservação do direito do trabalho é o objetivo a ser perseguido, diante das visões que têm como ponto de partida o desenvolvimento econômico, ou mais precisamente, a crise econômica" ${ }^{\natural 3}$. No entanto, não parece ao autor dessa tese que os pontos de vista indicados

Centro Studi di Diritto Del Lavoro Europeo “Massimo D`Antona, n 10, 2002, pág. 19. Disponível em http://www.lex.unict.it/eurolabor/ricerca/wp/int/hyde_n10-2002int.pdf (último acesso em 27/12/2012).

${ }^{82}$ GOLDSCHIMIDT, Rodrigo. Flexibilização dos Direitos Trabalhistas - Ações afirmativas da dignidade da pessoa humana como forma de resistência. São Paulo: LTR, 2009, pág. 114.

${ }^{83}$ SOUTO MAIOR, Jorge Luiz. "Direito do Trabalho e Desenvolvimento Econômico - Um Contraponto à Teoria da Flexibilização". in Juris Sintese. no 18, julho/agosto de 1999. 
sejam irremediavelmente incompatíveis. Embora em geral sejam antagônicos os interesses de empresários e trabalhadores, defende-se no presente texto que a flexibilização, em especial a combinada com medidas de segurança ao trabalhador, a flexicurity, pode atender satisfatoriamente as necessidades de ambos os lados da relação capital-trabalho.

A própria regulamentação e formalização de outros modos de contratação implica em um modo de flexibilizar o Direito do Trabalho de forma a atender as necessidades decorrentes da crise. Poder-se-ia argumentar que isso minaria o núcleo juslaboral voltado aos empregados, já que estimularia apenas a contratação de formas não subordinadas de trabalho. Ocorre que, como defendido nesta tese, esses modos de trabalho já existem e são utilizados à margem do direito, sendo que seu uso não eliminaria o contrato de trabalho clássico que continuará a ter amplo campo de atuação. A necessidade de novos meios de trabalho não quer dizer que somente essas modalidades é que passarão a ser utilizadas, podendo o trabalho clássico e as formas "modernas" coexistirem harmonicamente.

Sergio Pinto Martins bem identifica a tendência da flexibilização por necessidade de adaptação produtiva com proteção a outras formas de trabalho. Segundo o autor: "a tendência da flexibilização é decorrência do surgimento das novas tecnologias, da informática, da robotização, que mostram a passagem da era industrial para a pós-industrial, revelando uma expansão do setor terciário da economia. Assim, deveria haver uma proteção ao trabalhador em geral, seja ele subordinado ou não, tanto o empregado como também o desempregado. É nesse momento que começam a surgir contratos distintos da relação de emprego, como contratos de trabalho a tempo parcial, de temporada, de estágio etc. A flexibilização das normas do Direito do Trabalho visa assegurar um conjunto de regras mínimas ao trabalhador e, em contrapartida, a sobrevivência da empresa, por meio da modificação de comandos legais, procurando outorgar aos trabalhadores certos direitos mínimos e ao empregador a possibilidade de adaptação de seu negócio, mormente em épocas de crise econômica." 84

Cabe frisar que as teorias apocalípticas que previam que o movimento de flexibilização europeu iria implicar na total desregulamentação e precarização do trabalho não se mostraram corretas. Nesse diapasão, Marino Regini afirma que "na última década, nos países europeus, verificaram-se profundas mudanças na regulamentação do mercado de trabalho e das relações

\footnotetext{
${ }^{84}$ MARTINS, Sergio Pinto. op. cit., pág. 39.
} 
industriais. No entanto, em nenhum país (talvez com exceção da Grã-Bretanha) realizou-se uma pura e simples desregulamentação, como muitos auspiciavam no início da década e como muitos outros temiam. Por isso, pode-se falar em uma intensa atividade de re-regulamentação, no sentido de um contínuo ajustamento dos mecanismos que regulam o funcionamento do mercado de trabalho e as relações entre os atores sociais." 85 (tradução livre).

A modalidade de adaptação acima descrita não foi atingida pelas propostas de flexibilização até hoje implementadas e discutidas no país, mas é possível por meio de criteriosa aplicação de medidas da supracitada flexicurity, como será debatido a seguir, após a análise das investidas referentes às tipologias contratuais flexíveis.

\footnotetext{
${ }^{85}$ No original: "Nell'ultimo decennio, nei paesi europei si sono verificati profondi mutamenti nella regolazione del mercato del lavoro e delle relazioni industriali. Ma in nessun paese (forse con l'eccezione della GranBretagna) si è realizzata una pura e semplice de-regolazione, come molti all'inizio del decennio auspicavano e molti altri temevano. Per questo si può parlare di una intensa attività di ri-regolazione, nel senso di continui aggiustamenti dei meccanismi che regolano il funzionamento del mercato del lavoro e i rapporti fra le parti sociali." REGINO, Marino. "Tendenze comuni e differenze nella regolazione del mercato del lavoro e delle relazioni industriali in Europa". in W.P. Centro Studi di Diritto Del Lavoro Europeo "Massimo D Antona. no 7 , 2002, pág. 2. Disponível em http://www.lex.unict.it/eurolabor/ricerca/wp/int/regini_n7-2002int.pdf (último acesso em 26/12/2012).
} 


\section{TIPOLOGIAS CONTRATUAIS FLEXÍVEIS}

As primeiras medidas tomadas no campo do Direito do Trabalho europeu em busca da maior flexibilidade do mercado de trabalho foram voltadas, quase que exclusivamente, para a implantação e tipologias contratuais flexíveis. A preocupação com a segurança dos trabalhadores que passou a nortear as políticas denominadas de flexicurity, embora constasse das preocupações que fomentaram a flexibilização dos mercados, somente passaram a ser paulatinamente introduzidas após a ampla propagação das formas de contrato flexível.

Sobre o fenômeno identificado acima, Alberto Valdés Alonso aduz que "o certo é que até o ano de 2003, a organização flexível do trabalho que era invocada pelas diretrizes de emprego se traduziu, na realidade, no emprego de formas contratuais flexíveis, tais como o contrato por prazo determinado, o trabalho a tempo parcial e o recurso a empresas de trabalho temporário. Dessa maneira, ainda que seja certo que essa flexibilidade deveria ser acompanhada de uma segurança adequada, a realidade é que as ações empreendidas no âmbito da Estratégia Europeia de Emprego não apenas não definiram o ponto de equilíbrio entre flexibilidade e segurança, como nem mesmo definiram com clareza os atributos que caracterizam as medidas de seguridade." ${ }^{86}$

Foge ao escopo dessa tese o estudo minucioso da regulação de cada forma contratual flexível existente nos mais diversos ordenamentos jurídicos. Imprescindível, no entanto, uma

\footnotetext{
${ }^{86}$ No original: "Lo cierto es que hasta el año 2003, la organización flexible del trabajo que invocaban las directrices de empleo se tradujo, en realidad, en el empleo de formas contractuales flexibles tales como el contrato de duración determinada, el trabajo a tiempo parcial y el recurso a las empresas de trabajo temporal. De esta manera, si bien es cierto que a esta flexibilidad se le debía de acompañar de una seguridad adecuada, la realidad es que las acciones emprendidas en el marco de la Estrategia Europea del Empleo no solo no definieron el punto de equilibrio entre flexibilidad y seguridad sino que ni siquiera se definieron con claridad los atributos que caracterizarían las medidas de seguridad." VALDES ALONSO, Alberto. Derecho Del Trabajo, Rse Y Flexiguridad En El Seno De La Unión Europea: Una Dificil Convivência. Palestra proferida no X Congresso Europeu de Direito do Trabalho e da Seguridade Social em Sevilha de 21 a 23 de setembro de 2011, pág. 6. Disponível em http://www.europeanrights.eu/public/commenti/valdes_alonso_testo.pdf (último acesso em 02/01/2013).
} 
visão geral sobre as medidas adotadas como modo de adaptação do Direito do Trabalho e os resultados que atingiram por si só ou combinadas com outros fatores.

Assim, dentre as formas contratuais flexíveis propagadas nos ordenamentos jurídicos europeus pode-se destacar as seguintes:

(I) O contrato de trabalho por prazo determinado - Trata-se da mais genérica forma contratual flexível disponível. Diz-se flexível porque a forma padrão de contrato de trabalho subordinado é o contrato por prazo indeterminado. A medida gera bastante impacto no âmbito do Direito do Trabalho europeu, principalmente porque a maioria dos países de tal continente adota sérias restrições para a dispensa arbitrária, sem justo motivo. A rigidez contratual causada pelas limitações ao direito de dispensa sempre foi o principal ponto de crítica pelos empresários. O contrato por prazo determinado, com termo certo para seu final, veio a mitigar a rigidez dos contratos de trabalho padrão, de prazo indeterminado.

Deve ser destacado, no entanto, que as reformas flexibilizadoras não criaram o contrato de trabalho por prazo determinado que há muito já existe. O que se fez foi a ampliação da regulamentação e o aumento das hipóteses de cabimento do contrato a prazo. O contrato por prazo indeterminado continuou, e continua, a ser a regra. O contrato a prazo passou a ser aceito com maior ou menor intensidade, sendo que alguns países, como a Itália, inclusive permitiram que a negociação coletiva crie hipóteses de cabimento do contrato a prazo e fixe o percentual de tais contratos dentro de determinada organização produtiva ${ }^{87}$.

Não se pretende nesse texto, como já dito, analisar a fundo as diversas hipóteses de utilização do contrato a prazo determinado nos ordenamentos europeus, visto que tal tarefa desviaria o escopo da tese. É importante ressaltar, no entanto, a existência da diretiva

\footnotetext{
${ }^{87}$ Nesse sentido, Giuseppe Ferraro, ao comentar a flexibilização por meio dos contratos a prazo no direito italiano, afirma que "a norma, enquadrada em um processo e flexibilização controlada das relações de trabalho, delega à negociação coletiva efetuada pelas principais organizações sindicais a faculdade seja de introduzir novas hipóteses em que é consentido o contrato a prazo, seja de estabelecer percentuais admissíveis nos diversos contextos produtivos". No original: "la norma, nel quadro di un processo di flessibilizzazione controllata dei raporti di lavoro, delega alla contrattazone colletiva stipulata dalle principali OO.SS. la facoltà sia di introdurre ipotesi aggiuntive in cui è consentito il contratto a termine, sai di stabilire le pencentuali ammisibili nei diversi contesti produttivi.” FERRARO, Giuseppe. Tipologie di Lavoro Flessibile. Torino, G. Giappichelli, 2009, pág. 36.
} 
comunitária 1999/70/CE que trata de requisitos gerais da contratação por prazo determinado, destacando a preocupação para que o contrato sem termo continue a ser o padrão das relações de trabalho, apesar de reconhecer a necessidade do contrato com prazo determinado em certas situações.

O próprio preâmbulo da diretiva aduz que "as partes signatárias deste acordo reconhecem que, os contratos de trabalho sem termo são e continuarão a ser a forma mais comum no que diz respeito à relação laboral entre empregadores e trabalhadores. Reconhecem ainda que os contratos de trabalho a termo respondem, em certas circunstâncias, as necessidades tanto dos empregadores como dos trabalhadores. O presente acordo estabelece os princípios gerais e os requisitos mínimos relativos aos contratos de trabalho a termo, reconhecendo que a sua aplicação pormenorizada deve ter em conta a realidade e especificidades das situações nacionais, setoriais e sazonais. Afirma ainda a vontade dos parceiros sociais em estabelecerem um quadro-geral que garanta a igualdade de tratamento em relação aos trabalhadores contratados a termo, protegendo-os contra discriminações e a utilização dos contratos de trabalho a termo numa base aceitável tanto para empregadores como para trabalhadores." $" 88$

A diretiva conta com medidas para proteger os trabalhadores contratados a prazo de abusos e discriminações. Dentre as medidas estão a previsão de limitação para renovações, que devem ser justificadas, a definição de prazos e a estipulação de percentuais máximos de trabalhadores a prazo determinado, além da preferência para a contratação dos trabalhadores que já atuem a termo quando do surgimento de vagas para a prestação de serviços por prazo indeterminado.

No direito brasileiro, a regra geral também é a do contrato por prazo indeterminado. $\mathrm{O}$ contrato a prazo encontra regulamentação específica e poucas hipóteses de cabimento. De forma genérica, o parágrafo $2^{\circ}$ do artigo 443 da CLT determina que somente será válido o contrato por prazo determinado em se tratando: “a) de serviço cuja natureza ou transitoriedade justifique a predeterminação do prazo; b) de atividades empresariais de caráter transitório." Além disso, é prevista sua aplicação no contrato de experiência (alínea "c" do parágrafo $2^{\circ}$ do

\footnotetext{
88 Texto da diretiva 1999/70/CE disponível em http://eur-lex.europa.eu/LexUriServ/LexUriServ.do?uri= OJ:L:1999:175:0043:0048:PT:PDF (último acesso em 02/01/2013).
} 
artigo 443 da CLT); contrato de safra (artigo 14 da Lei $\mathrm{n}^{\circ}$ 5.889/73), o contrato do atleta profissional de futebol e o contrato especial da Lei $\mathrm{n}^{0}$ 9.601/98 (esse dentro da tentativa de flexibilização neoliberal), esse último dependendo de norma coletiva.

(II) Em seguida ao contrato por prazo determinado, merece atenção o contrato de trabalho a tempo parcial. Com efeito, o contrato de trabalho padrão, além de se dar por prazo determinado, é celebrado a tempo integral. Ou seja, a contratação base é para o módulo limite de horas e dias de trabalho previsto em cada legislação. As medidas flexibilizadoras apontam que nem sempre há necessidade da contratação de pessoal para desenvolvimento de atividades em tempo integral, sendo suficiente a prestação de serviços em alguns dias da semana, ou apenas por algumas horas diárias. Em contrapartida, afirma-se que o contrato a tempo parcial permite ao trabalhador desenvolver outras atividades paralelas, como o estudo, ou o cuidado com os membros da família. É certo, no entanto, que para ser considerado contrato de trabalho a tempo parcial, deve existir, na mesma situação, trabalhador a tempo integral, caso contrário seria o caso apenas de um trabalho a tempo integral em horário diferenciado.

Sergio Pinto Martins recorda que a questão do trabalho a tempo parcial contém previsão no direito internacional. Segundo o autor "a Convenção n 175 da OIT, e 1994, considera com trabalhador a tempo parcial o que, assalariado, tem atividade laboral com duração inferior à normal dos trabalhadores a tempo completo, calculada semanalmente, desde que este tenha a mesma atividade, efetuando o mesmo trabalho no mesmo estabelecimento $\left(\operatorname{art.~} 1^{0}\right)^{\text {, } 89}$. Frisa o citado professor que a norma em comento não foi ratificada pelo Brasil, o que não impede, no entanto, a existência de legislação específica a respeito do tema no ordenamento jurídico pátrio.

O direito italiano efetuou, no intervalo de três anos, duas reformas a respeito do contrato de trabalho a tempo parcial. A primeira delas altamente flexibilizadora, por meio do Decreto Legislativo $n^{\circ}$ 61/2000 e a segunda por meio do Decreto Legislativo 276/2003. Em linhas gerais, a regulamentação e estipulação das condições de trabalho a tempo parcial são delegadas à negociação coletiva..$^{90}$

\footnotetext{
${ }^{89}$ MARTINS, Sergio Pinto. Flexibilização das Condições de Trabalho. 4a ed., São Paulo: Atlas, 2009 , pág. 83.

${ }^{90}$.O Artigo 46 do decreto 276/2003 determina que "os contratos coletivos nacionais ou territoriais estipulados pelas associações de empregados e empregadores comparativamente de maior representatividade no plano nacional e os contratos coletivos empresariais estipulados pela representação sindical empresarial de que trata o
} 
Um sério problema identificado pela doutrina italiana a respeito dos contratos de trabalho a tempo parcial é o relativo à prestação de serviços extraordinários. Afirma Massimiliano Delfino que "muito frequentemente a contratação coletiva permite o recurso ao trabalho suplementar até o limite do horário de trabalho a tempo integral, ignorando, assim, a indicação do legislador de previsão de teto diverso para esse tipo de trabalho excedente. Em outros contratos, ainda, além da falta desse limite, não são nem mesmo precisadas as hipóteses de recurso ao trabalho suplementar, mas, ao contrário, se entende que o consenso individual é

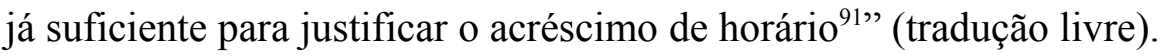

O contrato a tempo parcial é uma ferramenta importante para o atendimento de necessidades empresariais que não demandem a uso e trabalho em tempo integral. Negar essa forma de contratação acarreta a perda de postos de trabalho, já que o empregador deixa de contratar um trabalho além de suas necessidades e/ou aumenta os custos empresariais ao se subutilizar os serviços de um trabalhador. Ao mesmo tempo, a negativa do contrato a tempo

artigo 19 da Lei n $^{\circ} 300$ de 20 de maio de 1970 e sucessivas modificações, ou os estipulados pela representação sindical initária podem determinar condições e modalidades da prestação de serviços das relações de trabalho tratadas no inciso 2. Os contratos coletivos nacionais podem, ainda, prever para específicas figuras ou níveis profissionais modalidades particulares da atuação da disciplina conferida à contratação coletiva, nos termos do presente decreto. (tradução livre). No original: "I contratti collettivi nazionali o territoriali stipulati da associazioni dei datori e prestatori di lavoro comparativamente più rappresentative sul piano nazionale e i contratti collettivi aziendali stipulati dalle rappresentanze sindacali aziendali di cui all'articolo 19 della Legge 20

maggio 1970, n. 300, e successive modificazioni, ovvero dalle rappresentanze sindacali unitarie possono determinare condizioni e modalità della prestazione lavorativa del rapporto di lavoro di cui al comma 2 . I contratti collettivi nazionali possono, altresì, prevedere per specifiche figure o livelli professionali modalità particolari di attuazione delle discipline rimesse alla contrattazione collettiva ai sensi del presente decreto."

${ }^{91}$ No original: "molto spesso, la contrattazione colletiva consente il ricorso al lavoro supplementare fino al raggiungimento dell'orario a tempo pieno, tralasciando quindi l'indicazione del legislatore di prevedere dei tetti diversi per questo tipo di lavoro eccedente. In alcuni contratti, poi, oltre la mancanza di questo limite, no sono nemmeno precisate le ipotesi di ricorso al supplementare, ma, al contrario, si ritiene che il consenso individuale sia sufficiente a giustificare l'incremento di orario". DELFINO, Massimiliano. "La Contrattazione Colletiva sul Part-Time Dopo il D. LGS. 276/03: Profili Teorici e Applicativi”. in RUSCIANO, Mario; ZOLI, Carlo; ZOPPOLI, Lorenzo (coords.). Istituzioni e Regole del Lavoro Flessibile. Napoli: Editoriale Scientifica, 2006, pág. 382. 
parcial impede o trabalhador que não dispõe de tempo integral pelos mais variados motivos de se inserir no mercado de trabalho. No entanto, o alerta acima deve ser cuidadosamente considerado, sendo que a prestação de serviços extraordinários em contrato a tempo parcial descaracteriza totalmente o instituto.

No direito brasileiro a questão do trabalho a tempo parcial foi regulada por reforma legislativa ocorrida em 2001 que incluiu na Consolidação das Leis do Trabalho, além de normas a respeito da suspensão contratual para qualificação profissional, os artigos 58-A e 130-A. O texto do artigo 58-A é o seguinte: "Considera-se trabalho em regime de tempo parcial aquele cuja duração não exceda a vinte e cinco horas semanais. $\S 1^{\circ} \mathrm{O}$ salário a ser pago aos empregados sob o regime de tempo parcial será proporcional à sua jornada, em relação aos empregados que cumprem, nas mesmas funções, tempo integral. $\S 2^{\circ}$ Para os atuais empregados, a adoção do regime de tempo parcial será feita mediante opção manifestada perante a empresa, na forma prevista em instrumento decorrente de negociação coletiva." Já o artigo 130-A trata da questão relativa às férias dos empregados em tempo parcial.

Ainda sob o aspecto do direito brasileiro, deve-se frisar que a adoção de contratos de trabalho a tempo parcial se deu de modo bastante discreto, não atingindo as expectativas dos idealizadores da norma jurídica em comento. Os motivos, dentro do campo jurídico, podem estar relacionados à fragilidade do sistema sindical que pouco ou nada desenvolveu em termos de negociação coletiva voltada à adoção de referidos contratos, em parte devido ao receio e preconceito referente a tudo o que diz respeito à flexibilização, como foi ventilado no capítulo anterior.

(III) Ainda no que diz respeito à flexibilização contratual no campo da duração do trabalho, passa-se à análise do contrato de trabalho intermitente, também chamado de job on call. Tal modalidade contratual não foi ainda contemplada no ordenamento jurídico pátrio.

O nascimento e desenvolvimento do trabalho intermitente se deu, segundo Valentina Ruzzenenti ${ }^{92}$, nos Estados Unidos, com difusão para a Holanda e, em menor escala, para a Bélgica. No direito italiano a figura do trabalho intermitente foi introduzida na já citada

\footnotetext{
${ }^{92}$ RUZZENENTI, Valentina. "Lavoro Intermittente". in FAVALI, Giacinto (coord.). Codice di Diritto del Lavoro. $5^{\text {a }}$ ed., Piacenza: CELT, 2011, pág. 1024.
} 
reforma de 2003. Em conturbada evolução, o instituto foi removido do ordenamento peninsular em 2007, voltando à sua redação original em uma sucessiva reforma de 2008 . O trabalho intermitente é, assim, regulado pelo Decreto Legislativo n. 276/2003 em seus artigos 33 a 40.

Aduz a supracitada autora que "o trabalho intermitente pode, assim, ser definido como a tipologia contratual na qual o trabalhador se coloca, a tempo determinado ou indeterminado, à disposição do empregador, o qual pode usufruir da prestação de serviços 'chamando 'o trabalhador de quando em quando a desenvolver determinada atividade, com respeito a um período mínimo de pré-aviso (que pode chegar a um dia). ${ }^{93 "}$ (tradução livre).

O contrato em tela, no direito italiano, pode prever o pagamento de uma indenização de disponibilidade, pelo tempo que o trabalhador permanece aguardando a chamada para prestar serviços, o que não se confunde com o pagamento de salário, que somente será devido quando da efetiva convocação para a prestação de serviços.

Diferencia-se essa forma contratual da relação de emprego por conta do alto grau de incerteza e até mesmo ausência de habitualidade, já que a prestação de serviços somente se dará quando da necessidade do tomador de serviços.

Não faltam críticas ao contrato intermitente na realidade italiana. Com efeito, Rosario Santucci aponta que tal tipologia contratual é pouquíssimo utilizada em seu país e que é praticamente inutilizável em razão de incongruências no texto legislativo, do forte desequilíbrio contratual em favor da empresa e do total desinteresse das entidades sindicais na regulamentação da matéria que lhe foi delegada pela norma jurídica. ${ }^{94}$

\footnotetext{
${ }^{93}$ No original: "il lavoro intermittente può, dunque, essere definito come quella tipologia contrattuale nella quale il lavoratore si pone, a tempo determinato o indeterminato, a disposizione del datore di lavoro, il quale può usufruire della sua prestazione lavorativa 'chiamandolo` di volta di volta ad eseguire una determinata attività, nel rispetto di un periodo mínimo di preavviso (pari ad un giorno)”. RUZZENENTI, Valentina. op. cit., pág. 1025.

${ }^{94}$ Afirma o autor que "per un verso, si avanzano forti perplessità per uma fattispecie contrattuale molto squilibrata a favore della flessibilità dell impresa (...) per um secondo verso, emergono numerose incongruenze del testo legislativo, (...) per un ultimo verso, si palesa il desinteresse quasi totale della contrattazione collettiva nei confronti di tale forma di lavoro flessibile )...)" SANTUCCI, Rosario. "Il Lavoro Intermittente: Un Modello Contrattuale Inutilizato (E Inutilizzabile) di Lavoro Iperflessibile?". in Rusciano, Mario; ZOLI, Carlo; ZOPPOLI, Lorenzo (coords.). Istituzioni e Regole del Lavoro Flessibile. Napoli: Editoriale Scientifica, 2006, pág. 403.
} 
A modalidade contratual em comento, como visto, oferece poucos atrativos ao trabalhador, mas com uma regulamentação legal específica e efetiva participação sindical, poderia contribuir, no direito brasileiro, para trazer ao mercado formal de trabalho figuras habitualmente excluídas e que prestam serviços de natureza eventual, como garçons e entregadores que são convocados para dias de maior movimento em restaurantes e trabalhadores em empresas de eventos e festas.

(IV) Também estranho ao direito brasileiro é o contrato de trabalho repartido, chamado ainda de job sharing. Giuseppe Ferraro afirma que o instituto foi regulado pelo direito italiano na onda reformadora de 2003, pelo mesmo Decreto Legislativo ${ }^{\circ} 276$ que tratou do trabalho intermitente analisado acima, mas que já era encontrado nos ordenamentos jurídicos de Inglaterra, Alemanha e Finlândia.

A definição legal do contrato repartido no direito italiano é dada pelo item "1" do artigo 41 do Dl. 276 de 2003 que aduz: "o contrato de trabalho repartido é um contrato de trabalho especial mediante o qual dois trabalhadores assumem solidariamente o adimplemento de uma única obrigação laborativa. ${ }^{95}$ ",

Valentina Ruzzenenti diferencia o contrato repartido do contrato a tempo parcial lembrando que esse último se refere a apenas uma relação jurídica de trabalho para dois empregados. Afirma, ainda, que a peculiaridade mais evidente é que no contrato repartido há uma relação de solidariedade entre os trabalhadores e que o empregador pode, assim, exigir a prestação de serviços de qualquer dos trabalhadores indistintamente. ${ }^{96}$

Andrea Allamprese recorda que, em face da solidariedade, o risco da impossibilidade de manutenção da prestação de serviços recai de um empregado ao outro, que pode ser compelido pelo empregador ao adimplemento total da obrigação de prestar o trabalho. ${ }^{97}$

\footnotetext{
${ }^{95}$ No original: "il contratto di lavoro ripartito è uno speciale contratto di lavoro mediante il quale due lavoratori assumono in solido l'adempimento di una unica e idêntica obbligazione lavorativa".

${ }^{96}$ Nas palavras da autora: Rispetto al part-time nel lavoro ripartito vi è un solo contratto di lavoro subordinato e non due contratti di lavoro parziale. Inoltre, e ciò costituisce la peculiarità più evidente, nel rapporto di lavoro ripartito sussiste um vincolo di obbligatorietà solidale della prestazione lavorativa in capo a ciascun lavoratore: il che significa che vi è una sola identica obbligazione lavorativa, a cui entrambi i lavoratori sono coobbligati solidalmente. RUZZENENTI, Valentina. op. cit., pág. 1045.
} 
Sergio Pinto Martins aponta que o trabalho repartido é regulado na Alemanha por uma lei de 26 de abril de 1985, onde também é permitido o contrato de trabalho em equipe, podendo o empregador exigir a prestação de serviços de qualquer um dos membros em caso de impossibilidade de comparecimento dos demais. A lei prevê, ainda, a nulidade da dispensa de toda a equipe, devendo os empregados sobressalentes serem transferidos para outros cargos. Segundo o citado professor, "há, assim, a possibilidade de contratação de mais de uma pessoa para o posto de trabalho, podendo reduzir os efeitos do desemprego. Compreende a quebra do elemento pessoalidade, inerente ao contrato de trabalho, pois o empregado presta serviços pessoalmente, não podendo mandar outra pessoa em seu lugar. ${ }^{98 "}$

A figura em análise favorece o empregador na medida em que reduz seus riscos com o inadimplemento da mão-de-obra causado pelo absenteísmo, crítico em determinados ramos de atividade. Não gera, no entanto, maiores benefícios aos trabalhadores, exceto, talvez, uma maior oferta de postos de trabalho. Delicada, ainda, a questão relativa à divisão das horas de trabalho e pagamento, sendo certo que o empregador não irá arcar com a remuneração integral aos dois trabalhadores que dividem o tempo de serviço. A delegação de tais divisões à vontade individual dos trabalhadores envolvidos pode gerar controvérsias sérias, sendo importante um regramento legal mínimo e o suporte específico da contratação coletiva.

(V) Não se pode deixar de mencionar a figura do contrato de trabalho temporário. Enquadra-se tal contrato nas tipologias flexíveis analisadas no presente capítulo por conta de suas peculiaridades, especialmente quanto à duração, hipóteses de cabimento e, no direito brasileiro, a existência de uma terceira pessoa além de empregado e empregador.

Esclarecedora, a esse respeito, a lição de Sergio Pinto Martins de que "o contrato de trabalho temporário não deixa de ser uma espécie de contrato de trabalho de tempo determinado, porém com características específicas. Tem como sujeitos três pessoas: o trabalhador, o tomador dos serviços ou cliente e a empresa de trabalho temporário. ${ }^{99}$,

\footnotetext{
${ }^{97}$ De acordo com o autor: "il rischio dell'impossibilita sopravvenuta della prestazione da parte di uno dei lavoratori passa dal datore di lavoro all'altro coobligato, che può essere costretto alladempimento. ALLAMPRESE, Andrea. "Lavoro Ripartitto". in VALLEBONA, Antonio (coord.). I Contratti di Lavoro. Torino: UTET, 2009. Tomo II, págs. 1234/1235.

${ }^{98}$ MARTINS, Sergio Pinto. op. cit., pág. 121.

${ }^{99}$ MARTINS, Sergio Pinto, op. cit., pág. 77.
} 
No ordenamento jurídico pátrio o trabalho temporário é regulado pela Lei $n^{\circ} 6.019 / 74$. O trabalhador temporário tem relação de emprego com a empresa de trabalho temporário. Essa, por sua vez, fornece o trabalhador ao tomador de serviços, sendo que essa prestação não pode superar três meses (há previsão de possibilidade de prorrogação, por igual prazo e uma única vez, desde que atendidos os requisitos da portaria $n^{0} 550 / 2010$ do Ministério do Trabalho e Emprego). Somente é cabível a prestação de serviços temporários quando haja necessidade transitória da empresa para substituir pessoal regular e permanente ou pelo acréscimo extraordinário de serviços.

O trabalho temporário não deixa de ser uma solução para questões tanto de trabalhadores quanto de empresários. Com efeito, permite a prestação de serviços para complementação de renda de quem não possui possibilidade integral durante o ano, como ocorre com estudantes ao mesmo tempo em que desonera empresas que somente necessitam do trabalho em um período específico de tempo, quando do acréscimo de serviços, como ocorre com empresas com produção sazonal (panetones, ovos de páscoa etc.), ou quando tenham que substituir pessoal regular.

É grande a preocupação com a fraude envolvendo os contratos de trabalho temporário. Infelizmente é frequente o uso do mesmo trabalhador, sucessivamente, com a troca da empresa de trabalho temporário, tratando-se, por óbvio, de tentativa de mascarar uma relação de emprego por prazo indeterminado mantida diretamente com o tomador de serviços.

A busca pela regulamentação do trabalho temporário no direito estrangeiro também se preocupa com a questão da fraude. Em Portugal, a questão foi objeto de atenção do DecretoLei $\mathrm{n}^{\circ} 358$ de 1989 onde a exposição de motivos ressalta as características especiais do contrato temporário, a legitimidade e utilidade de sua existência e o problema de sua existência marginalizada ante a ausência de regulamentação ${ }^{100}$.

\footnotetext{
100 Merece destaque o seguinte trecho da exposição de motivos citada: "Reconhece-se que a especialidade que apresenta o trabalho temporário - contrato de trabalho «triangular» em que a posição contratual da entidade empregadora é desdobrada entre a empresa de trabalho temporário (que contrata, remunera e exerce poder disciplinar) e o utilizador (que recebe nas suas instalações um trabalhador que não integra os seus quadros e exerce, em relação a ele, por delegação da empresa de trabalho temporário, os poderes de autoridade e de direcção próprios da entidade empregadora) - foge à pureza dos conceitos do direito do trabalho e não se reconduz ao regime do contrato a termo nem se confunde com o regime de empreitada. Constitui também motivo
} 
Um argumento negativo é o de que o contrato de trabalho temporário poderia ser substituído pelo contrato de trabalho a prazo determinado, com a relação de emprego formando-se diretamente com o tomador de serviços, em geral mais sólido que a empresa de trabalho temporário e oferecendo melhores condições de trabalho, inclusive e especialmente no aspecto financeiro. Em contraponto a esse argumento, afirma-se que a empresa de trabalho temporário poderá realocar o trabalhador em outras empresas que demandem serviços temporários ao término da necessidade empresarial do tomador de serviços, oferecendo ao empregado maiores oportunidades de trabalho.

(VI) Ainda no capítulo a respeito das tipologias contratuais flexíveis, devem ser tecidos alguns comentários a respeito da terceirização de serviços. Ainda que não se trate especificamente de uma tipologia contratual, já que o trabalho terceirizado pode ser prestado de diversos modos, é certo que o trabalhador terceirizado se insere em uma situação atípica dentro do contexto da relação de emprego.

Segundo Gustavo Filipe Barbosa Garcia "a terceirização pode ser entendida como a transferência de certas atividades periféricas do tomador de serviços, passando a ser exercidas por empresas distintas e especializadas. Para o Direito do Trabalho, interessa o fato de se ter trabalhador prestando serviços ao ente tomador, mas possuindo relação jurídica com a empresa prestadora de serviços. A relação, assim, passa a ser triangular ou trilateral, pois na terceirização o empregado da empresa prestadora presta serviços ao tomador. ${ }^{101}$ ",

A primeira diferenciação a ser feita é com relação ao trabalho temporário analisado no tópico anterior. Embora em ambos os casos haja a interposição de um terceiro elemento, uma empresa prestadora de serviços, na hipótese do trabalho temporário o tomador de serviços contrata a prestação pessoal de determinado trabalhador, embora esse seja empregado da de preocupação social, sobretudo quando extravasa o âmbito em que a sua existência se mostra claramente legítima e útil, quer em termos económicos, quer em termos sociais. A falta de regulamentação do trabalho temporário tem conduzido ao seu desenvolvimento com foros de marginalidade, tendo sido, por isso, denunciada pelo Conselho das Comunidades, que, por Resolução de 18 de Dezembro de 1979, aconselhou a adopção de uma aç̧ão comunitária de apoio às medidas dos Estados membros, com o objectivo de assegurar tanto o controlo do trabalho temporário como a protecção social dos trabalhadores sujeitos a esta modalidade de trabalho.” Texto integral disponível em http://www.iapmei.pt/iapmei-leg-03.php?lei=167.

${ }^{101}$ GARCIA, Gustavo Filipe Barbosa. o.p. cit., pág. 171. 
empresa de trabalho temporário. Já na terceirização, via de regra, o tomador de serviços contrata a execução de determinada atividade a ser desenvolvida pela empresa contratada, independentemente da pessoa do trabalhador que será encaminhado para a prestação do trabalho. Ademais, no trabalho temporário a prestação de serviços é limitada no tempo (três meses, como visto acima), sendo que a terceirização pode prever um contrato por prazo indeterminado.

Pode-se argumentar que na terceirização o empregado é contratado regularmente em um vínculo de emprego por prazo indeterminado e que, assim, a relação jurídica não seria atípica e não se enquadraria no conceito de flexibilização. No entanto, é certo que a prestação de serviços terceirizados não se dá nos moldes clássicos da relação de emprego, já que por conta da necessidade da organização dos serviços empresariais, uma importante parcela da subordinação jurídica é transferida do real empregador, a empresa prestadora de serviços, para o tomador, que organiza e dirige a atividade produtiva. 


\section{Flexicurity - Definição - Análise - Aplicabilidade}

A análise das possíveis soluções para a crise do direito do trabalho identificada no início da presente tese e a demonstração de necessária evolução do paradigma de protecionismo do empregado para a proteção jurídica do trabalhador, não pode deixar de lado um estudo da chamada flexicurity, ou "flexisegurança" que vem ganhando destaque com relação ao Direito do Trabalho voltado à pessoa que trabalha em sentido amplo. Pelo contrário, acredita-se que um modelo sólido de flexicurity é ferramenta imprescindível para a modernização do Direito do Trabalho.

Em primeiro lugar, antes de se discutir a aplicabilidade ou não da flexicurity à realidade brasileira, uma vez que seu estudo e desenvolvimento são estranhos ao ordenamento jurídico nacional, cabe verificar de que efetivamente se trata o fenômeno, visto que a situação descrita pelo interessante vocábulo reúne aspectos opostos para o Direito do Trabalho, tal seja flexibilidade de um lado e segurança de outro.

Miriam Abu Sharkh afirma que o surgimento da flexicurity pode ser conceitualmente alinhado com o desenvolvimento das discussões a respeito da "terceira via" que tem dominado as discussões a respeito do mercado de trabalho, sendo essa própria, a "terceira via", uma opção entre o modelo ultra-liberal norte-americano e o sistema europeu considerado excessivamente rígido. ${ }^{102}$

José Affonso Dallegrave Neto aduz que a "flexisegurança" vem sendo debatida por todos os integrantes da União Europeia e que o conceito "pretende conciliar dois valores sensivelmente antagônicos, quais sejam a flexibilidade do mercado de trabalho e a segurança dos trabalhadores contra o desemprego." 103

\footnotetext{
${ }^{102}$ Aduz a autora, no original, que: "conceptually, the flexicurity debate can be grouped with the current third way discussion spawned by Esping-Andersen's "three worlds of welfare capitalism" (EspingAndersen, 1990). The"third" way pertains to a golden middle way between a hypothetical "European" and "US" model that has dominated much of the labour market rigidity discussion". SHARKH, Miriam Abu. Are there optimal global configurations of labour market flexibility and security?- Tackling the flexicurity oxymoron. Genebra: OIT, 2008. Disponível em http://www.ilo.org/wcmsp5/groups/public/---ed_emp/---emp_elm/--analysis/documents/publication/wcms_105102.pdf (último acesso em 28/12/2012).
} 
Guilherme Guimarães Feliciano, em análise de estudos da Comissão Europeia, destaca na "flexisegurança" a existência de componentes políticos, de flexibilidade e de segurança. Quanto aos primeiros, sustenta o autor a integração de "flexibilidade e segurança dos dispositivos contratuais; estratégias globais de aprendizagem e reciclagem profissional ao longo da vida útil; políticas públicas ativas e eficazes no mercado de trabalho; e regimes de seguridade social modernos." A flexibilidade consistiria em "permitir a cada um adaptar-se às transições entre as várias etapas da vida (...); organizar o trabalho em função das necessidades de produção e de competências; e facilitar a conciliação entre vida profissional e vida privada". Já a segurança, além do estímulo à conservação do emprego, implicaria em “dotar cada trabalhador de competências tais que lhe permitam evoluir na vida profissional e/ou encontrar um novo emprego; estabelecer subsídios de desemprego (...); e multiplicar as possibilidades de formação, reciclagem e capacitação para todos os trabalhadores, em especial quando são pouco qualificados e/ou mais idosos."104

Massimiliano Delfino socorre-se da definição de flexicurity dada pela comissão europeia para afirma que a noção de flexibilidade no mercado de trabalho identifica-se com as "transições virtuosas" que ocorrem na vida do trabalhador, nas passagens do desemprego ao trabalho, escola ao trabalho, de um emprego a outro e do trabalho à aposentadoria. De tal modo, a flexibilidade não se limita somente à liberdade de contratar e dispensar trabalhadores, tampouco que dizer que estão fadados ao fim os contratos de emprego a prazo indeterminado. A noção de segurança no mercado, por sua vez, identifica-se na capacidade do trabalhador de progredir na vida na esfera do trabalho e de ter acesso a novos postos de trabalho, sobretudo por meio de uma formação continuada ${ }^{105}$.

${ }^{103}$ DALLEGRAVE NETO, José Afonso. “Flexissegurança nas Relações de Trabalho. Que bicho é esse?”. in Revista Trabalhista: Direito e Processo, ano 7, $\mathrm{n}^{\circ}$ 25: LTR, 2008.

${ }^{104}$ FELICIANO, Guilherme Guimarães. Curso Crítico de Direito do Trabalho. São Paulo: Saraiva, 2012, pág. 141.

${ }^{105}$ No texto original: "Secondo la Commissione, la flexibility nel mercato del lavoro consiste nelle "transizioni virtuose" cha caratterizzano la vita lavorativa, ovvero nei passaggi dalla disoccupazione al lavoro, dalla scuola al lavoro, da un rapporto di lavoro ad un altro, dal lavoro alla pensione, e non è limitata soltanto alla libertà per le imprese di assumere o licenziare, né implica che i contratti a tempo indeterminato siano ormai superati. Invece, la sicurezza nel mercato è vista come la capacità del lavoratore di realizzare un miglioramento nella vita lavorativa 
O Professor alemão Ute Klammer ensina que, em linhas gerais, a flexicurity procura encontrar o balanço entre flexibilidade e segurança, surgindo como alternativa para as teorias que pregam a desregulamentação total do mercado de trabalho e as normas vigentes consideradas excessivamente rígidas no campo do Direito do Trabalho e da Política Social ${ }^{106}$.

Segundo Elke Viebrock e Jochen Clasen, pesquisadores da Universidade de Edimburgo, na Escócia, a chamada flexicurity não corresponde exatamente a um conceito jurídico, mas a uma série de medidas que buscam uma espécie de "fórmula mágica" para superar as evidentes tensões entre flexibilidade do mercado de trabalho e segurança social, com oferta do que há de melhor em cada situação. ${ }^{107}$

O Ministro do Trabalho dinamarquês Claus Hjort Frederiksen simplifica a definição ao afirmar que a flexicurity torna mais fácil a contratação de pessoal pelas empresas porque essas empresas podem dispensar os trabalhadores facilmente. ${ }^{108} \mathrm{~A}$ definição resumida adotada não corresponde, no entanto, a todos os aspectos da flexicurity, tanto que não se pode, atualmente, falar na existência de um modelo desse tipo no Brasil, embora a dispensa do trabalhador no país corresponda, ainda, a um direito potestativo do empregador, com poucas medidas efetivas de garantia de emprego.

e di accedere a nuovi lavori, in particolar modo attraverso la formazione continua. DELFINO, Massimiliano. Diritti Sociali e flexicurity. Napoli, 2008, pág. 19. Disponível em http://www.europeanrights.eu/ index.php? funzione=S\&op=5\&id=145 (último acesso em 08/01/2013).

${ }^{106}$ No original: "the general consensus is that the goal of flexicurity is to strike a new balance between flexibility and security, and therefore to provide an alternative to a deregulation-only policy - and an alternative to a continuation of the current rigid regulations in the area of labour law and social policy". KLAMMER, Ute. "flexicurity Schemes". in Recounciling Labour Flexibility with Social Cohesion - Facing the Chalenge, Trends in Social Cohesion, ${ }^{\circ}$ 15: Council of Europe Publishing, 2005, pág. 158.

${ }^{107}$ No original, ao estudarem a flexicurity, lembram os autores que: "it promises to deliver a magic formula to overcome the tensions between labour market flexibility on the one hand and social security on the other hand by offering 'the best of both worlds". VIEBROCK, Elke; CLASEN, Jochen. "State of the Art - flexicurity and Welfare Reform: a Review" in Socio-Economic Review. v. 7, issue 2: Oxford, 2009.

${ }^{108}$ No original, "In simple terms: It makes it easy for companies to hire people because they can also fire them easily." FREDEIKSEN, Claus Hjort. flexicurity, or How the work force, employers and the government in a small country got together in adapting to market demands in a globalized world. Genebra: OIT, 2008. Disponível em http://www.ilo.org/wcmsp5/groups/public/@dgreports/@dcomm/documents/newsitem /wcms_093856.pdf. (último acesso em 01/12/2012). 
Brendan Burchel admite que as definições de flexicurity não são unânimes, mas que em geral apresentam em comum quatro componentes: (i) flexibilidade na contratação e dispensa de trabalhadores; (ii) melhora na empregabilidade por meio de treinamentos e políticas ativas de mercado de trabalho; (iii) apoio de um sistema de seguridade social; e (iv) diálogo social com alto nível de confiança ${ }^{109}$. Prossegue o autor afirmando que os benefícios econômicos da flexicurity consubstanciam-se em "mercados de trabalho flexíveis e adaptações às mudanças dos mercados e novas tecnologias", enquanto os benefícios sociais são de "redução do desemprego, em particular o desemprego de longo prazo; redução da pobreza durante os períodos de desemprego; e redução do medo e ansiedade que são associados em geral com a perda do emprego" $" 110$.

O fenômeno, como visto, é bastante amplo e não comporta uma única definição. Ademais, há políticas que hoje são enquadradas na concepção de flexicurity e que já existiam antes mesmo da nomenclatura ter sido criada pelos estudiosos do mercado de trabalho, como as medidas que buscam mitigar dificuldades econômicas, ao mesmo tempo que não desamparam o trabalhador (i.e. a suspensão temporária do contrato de trabalho, vinculada à participação em cursos de formação e com pagamento de bolsa auxílio).

As tensões e aparentes contradições mencionadas entre os termos flexibilidade e segurança decorrem da constatação que em geral as medidas de flexibilização do mercado de trabalho e em especial a flexibilização do Direito do Trabalho, se por um lado podem ajudar na criação de postos de trabalho, por outro acabam por ser acompanhadas em um decréscimo nas condições de econômicas e de proteção jurídica dos trabalhadores. A desconfiança gerada pelas políticas de flexicurity é fundada no receio de que somente o lado da flexibilidade, que se associa, via de regra, com o atendimento de interesses dos empresários, é que receberá a atenção digna. Teme-se que o vocábulo segurança seja relegado a segundo ou terceiro plano, não passando de uma justificativa estatal para a redução de direitos. Procurar-se-á demonstrar, no entanto, que não só é possível um equilíbrio entre a flexibilidade e a segurança, como é

${ }^{109}$ BURCHELL, Brendan. Can flexicurity reduce the relationship between job insecurity and psychological wellbeing?. Cambridge: OIT, 2008. Disponível em http://www.ilo.org/wcmsp5/groups/public/---ed_protect/--protrav/---travail/documents/meetingdocument/wcms_123864.pdf (último acesso em 28/12/2012).

${ }^{110}$ BURCHELL, Brendan. op. cit. 
possível e necessário se fazer a reforma tendo em mente o caráter de direitos fundamentais de um núcleo mínimo de direitos de todos os trabalhadores.

Por outro ângulo, deve ser destacado que o estudo da flexicurity, no que diz respeito à primeira parte do vocábulo, da flexibilização, diferencia-se do desenvolvimento teórico da flexibilização do Direito do Trabalho, analisada em capítulo próprio da presente tese, especialmente com relação ao conceito subjetivo. Com efeito, enquanto as teorias de flexibilização preocupam-se exclusivamente com os interesses do mercado de trabalho do ponto de vista da demanda empresarial e possibilidades econômicas, os estudiosos da flexicurity analisam as possibilidades e necessidades da flexibilização também sob a ótica do trabalhador.

A flexibilização, ou melhor dizendo, a flexibilidade, que atende os interesses do trabalhador pode ser identificada, por exemplo, em políticas que permitem ao trabalhador conciliar a atividade econômica de subsistência com o tempo livre para o lazer e convívio familiar. O trabalho, embora essencial para o ser humano, não pode ser visto como um fim. Trabalha-se para bem viver, mas não se deve viver para trabalhar, o que reduziria o ser humano à figura do escravo, senão de um semelhante, um escravo do capital e dos interesses econômicos.

A flexicurity surge, assim, como uma alternativa para que as necessidades de flexibilização do mercado de trabalho em face de demandas econômicas não se dê em prejuízo direto do trabalhador com diminuição de seu padrão de vida e sobretudo para que seja garantida a manutenção de um mínimo de segurança nos aspectos jurídicos e econômicos, atendendo a interesses mútuos de capital e trabalho, sempre que possível.

Importante lembrar também que o caráter da igualdade pode e deve ser considerado como elemento integrante das políticas de flexicurity. Nesse sentido, afirma Loredana Zappalà que "na perspectiva da flexicurity, o princípio da igualdade tem sido considerado cada vez como um direito de todos - homens, mulheres, idosos, trabalhadores potencialmente em desvantagem - a iguais oportunidades no mercado de trabalho, como direito dos outsider não serem penalizados em relação aos insider, como direito dos trabalhadores mais frágeis de não serem indiretamente discriminados pela aplicação de critérios aparentemente neutros, como o de serem empregados com fórmulas contratuais flexíveis, como direito dos trabalhadores 
flexíveis tout court diretamente discriminados por motivos conexos a seu status contratual. ${ }^{111}$ ", (tradução livre).

A implantação da flexicurity se dá por meio de medidas intervencionistas estatais diversas, englobando políticas do estado de bem-estar-social (o chamado welfare state), em combinação com intenso diálogo social envolvendo trabalhadores, empresários, as entidades representativas de ambos, como sindicatos e centrais sindicais, além de representantes do Estado, juristas, economistas e representantes da sociedade civil como um todo.

Como inicialmente destacado, por um lado procura-se atender as necessidades do mercado com modos flexíveis de trabalho, implicando em uma mudança de paradigma do contrato de trabalho standard, o relativo à relação de emprego tradicional, passando para formas até então atípicas de trabalho que melhor se coadunem com as demandas econômicas. Por outro lado, as medidas de política social, nessas podendo ser incluído também o Direito do Trabalho, devem ser voltadas a garantir proteção e segurança aos que mais necessitam, que sem dúvida são os trabalhadores, historicamente inseridos no lado mais fraco da relação entre capital e trabalho.

Em linhas gerais, Ricardo Nascimento, advogado lusitano, afirma sobre o elemento em análise que "a flexisegurança, conceito importado da Dinamarca, trata-se aos olhos de muitos, de uma receita mágica para o gravíssimo problema de desemprego europeu. Neste modelo, quanto maior for a flexibilidade, maior proteção será dada aos trabalhadores e é na experiência dinamarquesa e de outros países do norte da Europa que se encontra o mais elevado nível de apoio ao desempregado, ao mesmo tempo que se dá aos empregadores mais flexibilidade nos despedimentos". ${ }^{112}$

\footnotetext{
${ }^{111}$ No texto original: "Nella prospettiva della flessicurezza, il principio di eguaglianza è stato, così, sempre più spesso, declinato come diritto di tutti - uomini, donne, anziani, lavoratori potenzialmente svantaggiati - alle pari opportunità nel mercato del lavoro, come diritto degli outsider a non essere penalizzati rispetto agli insider, come diritto dei lavoratori più deboli a non essere indirettamente discriminati tramite l'applicazione di criteri apparentemente neutri, quali l'essere impiegati con formule contrattuali flessibili, come diritto dei lavoratori flessibili tout court a non essere direttamente discriminati per motivi connessi al loro status contrattuale." ZAPPALÀ, Loredana. Flessicurezza, Pari Opportunita' E Non Discriminazione: I Percorsi (Quasi Sempre) Virtuosi Delle Politiche E Del Diritto Sociale Europeo. 2008, pág. 2. Disponível em http://www.europeanrights.eu/index.php?funzione=S\&op=5\&id=201 (último acesso em 10/01/2013).

${ }^{112}$ NASCIMENTO, Ricardo. "Flexisegurança ou Flexibilizar a Insegurança?". in Revista O Advogado, no 36, 2007 disponível em www.oadvogado.direitonline.com/artigo/artigo.asp?id=36
} 
O nascimento da flexicurity, como visto, se deu na Dinamarca, com difusão para a Holanda e posteriormente para outros países da União Europeia. Embora o foco das primeiras medidas tenha sido o combate ao desemprego, certo é que passou-se a enxergar na flexicurity a possibilidade de enfrentar não somente a falta de trabalho, mas sobretudo a falta de boas condições de trabalho, contexto no qual se insere a situação dos que trabalham de modo informal, ou sem o reconhecimento de direitos mínimos pelo ordenamento jurídico.

A proposta de aplicação dos conceitos de flexicurity da Dinamarca para o resto da Europa partiu do "Green Paper", ou "Livro Verde" da Comissão das Comunidades Europeias que se inicia aduzindo que seu propósito é "lançar o debate público na UE de como o Direito do Trabalho pode evoluir para dar suporte ao objetivo da "Estratégia de Lisboa" de atingir o crescimento sustentável com mais e melhores empregos. A modernização do Direito do Trabalho constitui um elemento chave para o sucesso da adaptabilidade de trabalhadores e empresas. Esse objetivo deve ser perseguido à luz dos objetivos da Comunidade de pleno emprego, produtividade do trabalho e coesão social."

Prossegue o relatório aduzindo que "a proliferação de diferentes formas contratuais surgiu na ausência de uma mais compreensiva adaptação do Direito do Trabalho e da negociação coletiva em face das céleres mudanças no desenvolvimento da organização do trabalho e da sociedade". De tal forma, os empregadores enfrentam o problema dos altos custos e os trabalhadores contam com o crescimento do número de postos de trabalho, além de poderem balancear os horários de trabalho com o convívio familiar e o estudo. Alerta o relatório, no entanto, que a flexibilidade, por si só, está associada a efeitos deletérios, com os trabalhadores restando presos em uma sucessão de contratos de curto prazo e baixa qualidade, sem a adequada proteção social ${ }^{114}$.

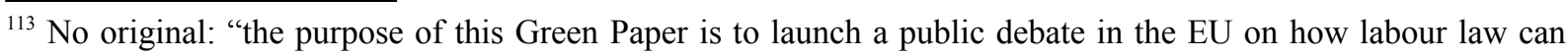
evolve to support the Lisbon Strategy's objective of achieving sustainable growth with more and better jobs. The modernization of labour law constitutes a key element for the success of the adaptability of workers and enterprises. This objective needs to be pursued in the light of the Community's objectives of full employment, labour productivity and social cohesion." COMISSÃO DAS COMUNIDADES EUROPEIAS. Green Paper Modernising Labour Law to Meet the Challenges of the 21 st Century. Bruxelas: European Comission, 2006, pág. 3.
} 
Conclui o relatório em comento que "no contexto da globalização, a reestruturação em andamento e o movimento em direção a uma economia baseada no conhecimento, os mercados de Trabalho europeus devem ser a mesmo tempo mais inclusivos e com maior poder de resposta a inovações e mudanças" ${ }^{115}$.

Considerando-se que a realidade dinamarquesa, principalmente, e de outros países membros da União Europeia que deverão seguir os contornos do citado "Livro Verde", tanto no campo social, como no jurídico e no econômico é bastante diversa da brasileira, é necessária, para melhor compreensão, uma análise da origem do instituto e posterior verificação de compatibilidade na transferência e aplicabilidade para o direito brasileiro.

O próprio governo dinamarquês vangloria-se de sua política de flexicurity como modo de enfrentamento dos impactos da globalização na economia e no mercado de trabalho. Definições e reflexões a respeito podem ser encontradas no sítio oficial do país na rede mundial de computadores. ${ }^{116}$

\footnotetext{
114 No original: "A proliferation of different contractual forms has emerged in the absence of a more comprehensive adaptation of labour law and collective agreements to rapidly changing developments in work organisation and society. By availing of non-standard contractual arrangements, businesses seek to remain competitive in the globalised economy by avoiding inter alia the cost of compliance with employment protection rules, notice periods and the costs of associated social security contributions. Administrative burdens associated with the employment of regular employees also have a significant influence on employment growth, particularly in small firms. Non-standard as well as flexible standard contractual arrangements have enabled businesses to respond swiftly to changing consumer trends, evolving technologies and new opportunities for attracting and retaining a more diverse workforce through better job matching between demand and supply. Workers are also afforded greater choice particularly as regards arrangements for working time, increasing career opportunities, a better balance between family life, work and education as well as more individual responsibility. (...)However, there is evidence of some detrimental effects associated with the increasing diversity of working arrangements. There is a risk that part of the workforce gets trapped in a succession of short-term, low quality jobs with inadequate social protection leaving them in a vulnerable position. Such jobs may however serve as a steppingstone enabling people, often those with particular difficulties, to enter the workforce." COMISSÃO DAS COMUNIDADES EUROPEIAS. o.p. cit. págs. 7/8.

${ }^{115}$ No texto: "In the context of globalisation, ongoing restructuring and the move towards a knowledgebased economy, European labour markets need to be both more inclusive and more responsive to innovation and change." COMISSÃO DAS COMUNIDADES EUROPEIAS o.p. cit., pág. 8.
} 
A explicação oficial do governo da nação escandinava é de que a flexicurity no país constitui uma relação triangular formada pela flexibilidade, segurança e políticas ativas de mercado de trabalho. Em primeiro lugar, são oferecidas regras flexíveis para a contratação e dispensa de trabalhadores, com a informação de que cerca de $25 \%$ dos trabalhadores privados mudam de postos anualmente. Em segundo lugar, no campo da segurança, o modelo dinamarquês oferece um sólido sistema de seguro desemprego que garante renda que pode chegar a 90\% da remuneração do trabalhador, com períodos de duração e valores variando de acordo com requisitos definidos legalmente. O terceiro lado do triângulo é formado por políticas ativas de incentivo ao mercado de trabalho, envolvendo medidas educativas, de criação de empregos e de realocação de trabalhadores, com investimentos correspondentes a $1,5 \%$ do Produto Interno Bruto do país. ${ }^{117} \mathrm{O}$ modelo é focado na promoção da garantia de trabalho em detrimento à garantia de emprego ou de um mesmo posto de trabalho, em contraponto, por exemplo, às políticas de limitação de dispensas.

Em uma explicação do sistema triangular, o Professor Per Kongshoj Madsen aduz que embora seja grande o número de trabalhadores dispensados, a maioria encontra novos postos de trabalho após um curto período de desemprego e aqueles que não o fazem rapidamente são assistidos pelo Estado com medidas de bem-estar-social e políticas ativas relacionadas ao mercado de trabalho. ${ }^{118}$

Observe-se que a tentativa de transposição de tais políticas já para os vizinhos países da União Europeia constitui tarefa não desprovida de severas dificuldades, demandando medidas que podem ser caracterizadas revolucionárias. Tal se dá por prevalecer na ampla

\footnotetext{
${ }^{116}$ Destaca-se o seguinte texto, no original, a respeito do citado uso da "flexsecurity" para superar os desafios da globalização: "When people talk about the Danish labour market they often use the term flexicurity to describe the model which is successfully managing the challenges of globalisation and securing steady economic growth and employment" in http://denmark.dk/en/society/welfare/flexicurity (último acesso em 25/11/2012).

${ }^{117}$ Dados disponíveis em http://denmark.dk/en/society/welfare/flexicurity.

${ }^{118}$ Nas palavras do pesquisador escandinavo: “A large number of workers are affected by unemployment every year, but that most of them return to employment after a short spell of unemployment. Those who do not quickly go back into employment, are assisted by active labour market programmes, before reentering a job". MADSEN, Per Kongshoj. "The Danish Model of 'flexicurity': A Paradise With Some Snakes". in SARFATI, Hedva; BONOLI, Giuliano, (coords.). Labour Market and Social Protection Reforms in International Perspective. Aldershot: Ashgate, 2002, pág. 244. (versão digital).
} 
maioria dos países europeus continentais um sistema jurídico de proteção da relação de emprego com medidas que obstam ou limitam firmemente a dispensa arbitrária ou sem justa causa. A alteração do paradigma da proteção do emprego para a garantia de trabalho e recolocação no mercado, ainda que com diversas mudanças de postos, demanda esforços consideráveis, em especial para se evitar a discriminação entre trabalhadores típicos e atípicos, com crescimento da temida precarização das condições de trabalho para os que atuam em formas flexíveis de labor.

A União Europeia, assim, por meio de grupo coordenado pelo Professor Ton Wilthagen, publicou relatório em 2007 compilando diversas práticas relacionadas à flexicurity adotadas por seus membros ${ }^{119}$. A análise, ainda que breve de tais práticas é bastante relevante para a averiguação do sucesso ou não desse novo paradigma jurídico-social-econômico, merecendo atenção o fato de que se enquadram nas definições da Comissão Europeia de flexicurity medidas profundamente diversas umas das outras.

De acordo com o supracitado relatório, pode-se identificar as seguintes políticas de "flexisegurança", classificadas conforme o país de implementação:

(I) Espanha - "promoção de contratos por prazo indeterminado com a preservação da flexibilidade". Destaca-se a existência de uma realidade próxima à brasileira, com a previsão de contratos a prazo indeterminado com grande arcabouço de proteção jurídica, coexistindo com contratos a prazo com baixa proteção e alta rotatividade, com poucos incentivos para investimento nas relações de trabalho. Foram adotadas políticas de incentivo fiscal para transformação de contratos temporários em contratos por prazo indeterminado, visando resultados em relação aos grupos mais necessitados, como mulheres, jovens e trabalhadores há muito desempregados. ${ }^{120}$ Os resultados de tais medidas, no entanto, não corresponderam até o presente momento aos anseios governamentais de promoção do emprego, enfrentado a Espanha, ainda, níveis de desemprego extremamente altos. ${ }^{121}$

\footnotetext{
119 WILTHAGEN, Ton (coord.). flexicurity Practices. Bruxelas: European Commission, 2007, disponível em http://ec.europa.eu/employment_social/employment_strategy/pdf/flexi_practices_en._(último acesso em 30/11/2012).

${ }^{120}$ WILTHAGEN, Ton (coord.). op. cit., pág. 3.

${ }^{121}$ Conforme dados do "Instituto Nacional de Estadistca", publicados em 26 de outubro de 2012, o número de desempregados na Espanha no terceiro trimestre de 2012 alcançou 5.778 .100 de pessoas, ou 25,02\% da
} 
(II). Holanda - "padronização do trabalho flexível". As medidas tomadas na Holanda buscam limitar o uso contínuo de contratos a prazo determinado, fomentar o uso de agências de emprego, com grande influência da negociação coletiva em detrimento da legislação estatal e a inserção de normas legais para regularizar o trabalho "não standard", com um mínimo de proteção, remuneração e ferramentas protetivas contra a fraude. As medidas procuram atender principalmente os interesses do capital e dos trabalhadores em contratos flexíveis, incluindo temporários e autônomos. De especial interesse para a tese em desenvolvimento é a constatação de que a extensão de direitos relativos à segurança do contrato, remuneração mínima e previdência social a trabalhadores que antes não o tinham, como temporários e autônomos, permite atender aos interesses econômicos de contratação flexível sem implicar precarização de direitos dos trabalhadores. ${ }^{122}$

(III). Eslovênia - "regulação de agências de trabalho temporário e aumento da flexibilidade do mercado de trabalho". As medidas autorizam a maior utilização do trabalho temporário, criando legislação específica para o tema, como ocorre no direito brasileiro com a Lei $n^{\circ} 6.019$ de $1974 .{ }^{123}$

(IV). Hungria - "diversidade contratual, segurança e igualdade de tratamento". Alterações no Código de Trabalho do país determinaram, por exemplo, a igualdade de tratamento entre empregados em tempo parcial e empregados em tempo integral, com observância apenas da proporcionalidade de horas trabalhadas. ${ }^{124}$

Medidas de não-discriminação como essas podem ser adotadas ao se permitir a contratação de trabalhadores terceirizados, com ou sem vínculo de emprego, como forma de proteção do trabalho humano, independentemente das necessidades empresariais.

(V). Alemanha - "aumento nas opções de jornada de trabalho para empregados e empregadores". Observadas as limitações quanto ao número de empregados em cada empresa,

população ativa. Dados disponíveis em http://www.ine.es/daco/daco42/daco4211/epapro0312.pdf.

${ }^{122}$ Destaca o autor, ao tratar da extensão de direitos a trabalhadores temporários de agências de fomento que: "By extending rights to these workers with respect to social security, pensions and the prospect of a more secure contract, the flexibility offered to employers is matched by a reasonable degree of security for employees. WILTHAGEN, Ton (coord.). op. cit., pág. 4.

${ }^{123}$ WILTHAGEN, Ton (coord.). op. cit., pág. 5.

${ }^{124}$ WILTHAGEN, Ton (coord.). op. cit., págs. 6/7. 
o trabalhador com mais de seis meses de casa tem o direito de pleitear a mudança do contrato em tempo integral para o contrato a tempo parcial, com prioridade em relação a novos empregados para voltar ao contrato integral. A medida encontra seu maior âmbito de aplicação em relação a trabalhadores que retornam das licenças maternidade e paternidade. ${ }^{125}$

(VI) Reino Unido - “jornada de trabalho flexível e proibição de discriminação por idade".

(VII) Bélgica - “'Career Break'; suporte à transições do mercado de trabalho" - A primeira medida pode ser traduzida como uma espécie de licença-remunerada, mas não pelo empregador. No sistema belga, durante sua carreira, o empregado de empresas com mais de dez empregados tem direito a até um ano de licença, mantendo seu posto de trabalho ao retorno, sendo que durante a interrupção recebe um auxílio financeiro estatal, espécie de benefício previdenciário. A finalidade da norma é permitir o aprimoramento pessoal e profissional, bem como o convívio familiar do empregado. O segundo aspecto indicado quanto às inovações belgas diz respeito a medidas estatais de suporte à reestruturação do mercado, onde cortes de pessoal devem ser negociados e identificados em um plano pré-aprovado, com intervenção obrigatória do estado na recolocação de empregados, treinamento e pagamento de benefícios durante o desemprego. ${ }^{126}$

(VIII) Polônia - "suporte aos desempregados recém egressos das escolas/universidades por meio de redução de custos de contratação pelos empregadores". Programas de "primeiroemprego" financiados pelo Estado com redução de carga tributária e previdenciária para empregadores que contratem recém egressos de escolas e universidades. ${ }^{127}$ Trata-se de mais uma política voltada para o combate ao desemprego, especialmente o de jovens. Não é o foco da presente tese, mas é medida que pode ser adotada com êxito pelo ordenamento pátrio.

(IX) Eslováquia - “suporte aos desempregados em estado de desvantagem”. Incentivos específicos à contratação de trabalhadores que se encontram em desvantagem em relação aos demais, especificamente recém egressos de escolas e universidades, jovens, maiores de cinquenta anos e pessoas há maior tempo desempregadas. As medidas incluem incentivos

\footnotetext{
${ }^{125}$ WILTHAGEN, Ton (coord.). op. cit., págs. 7/8.

${ }^{126}$ WILTHAGEN, Ton (coord.). op. cit., págs. 9 e 13.

${ }^{127}$ WILTHAGEN, Ton (coord.). op. cit., págs. 15.
} 
previdenciários e fiscais. ${ }^{128}$ Os comentários tecidos acima com relação à realidade polonesa são também aqui aplicáveis. Pode-se destacar, ainda, que a expressão "desempregados em estado de desvantagem" pode ser interpretada de forma muito mais ampla, justificando a adoção de ações afirmativas diversas para reduzir a desigualdade entre os trabalhadores.

(X) Áustria - "garantia de mobilidade no mercado de trabalho". A novidade adotada pelo direito austríaco é, em muitos aspectos, similar ao sistema de Fundo de Garantia do Tempo de Serviço existente no ordenamento pátrio. Com efeito, as alterações no modelo do país europeu em análise instituíram um fundo de provisões para o trabalhador ("mitarbeitervorsorgekassen"), com depósitos mensais a cargo do empregador e que substituem indenizações por ruptura contratual. O escopo do fundo é permitir a diluição do custo de dispensa ao longo do contrato, tornando o desligamento menos custoso e garantindo a mobilidade do mercado de trabalho. Ao trabalhador, por sua vez, há a possibilidade, a sua escolha, de manter um fundo de poupança, transferindo a quantia disponível para o novo emprego quando a recolocação em novo posto se dê em curto período de tempo. ${ }^{129}$

(XI) Itália - "preservação da diversidade contratual com o incremento da segurança social". O direito italiano conta com um ampla gama de modalidades contratuais flexíveis, como foi analisado em capítulo anterior da tese, mas para evitar a precarização e promover a fixação do trabalhador, aumentou o valor de contribuições previdenciárias para contratos temporários e outras formas de trabalho flexível. Destaque-se que embora o escopo seja o mesmo de outras situações analisadas, a promoção da segurança do trabalho, a medida, ainda que também incluída como flexicurity pela Comissão Europeia, é diametralmente oposta à adotada por outros países que reduziram taxas sobre modalidades flexíveis de labor para aumentar a empregabilidade.

Ainda a respeito da aplicação da flexicurity fora da Dinamarca, Devashish Mitra e Priya Ranjan relatam a experiência francesa aduzindo, em tradução livre, que "algumas das reais aplicações do conceito de flexicurity fora da Dinamarca estão na França, onde foram introduzidos "contratos-missão" com finalidade específica de trinta e seis meses de duração. Ao final do contrato, dependendo da necessidade empresarial e do desempenho do

\footnotetext{
${ }^{128}$ WILTHAGEN, Ton (coord.). op. cit., págs. 15/16.

${ }^{129}$ WILTHAGEN, Ton (coord.). op. cit., pág. 11.
} 
trabalhador, a empresa pode optar pela conversão do contrato em prazo indeterminado. Isso concede à empresa maior flexibilidade, especialmente ao tratar com choques decorrentes da grande competição de produtos importados. Também na França, a agência pública nacional de emprego passou a controlar o seguro-desemprego. Isso tornou possível uma melhor fiscalização e, ao mesmo tempo, melhorou a qualidade dos serviços. Ademais, o sistema de treinamento vocacional está sendo reformado em busca de melhor desempenho."130

Verifica-se, portanto, que a questão da flexicurity pode ser desenvolvida em múltiplas facetas, sendo citadas treze nações, as doze acima e a Dinamarca com seu modelo tríplice, todas com medidas próprias, com resultados atingidos em diversos níveis. Não é, assim, um conceito fechado, mas um paradigma de desenvolvimento de medidas jurídico-políticoeconômicas para buscar conciliar a flexibilidade do mercado de trabalho com a segurança dos trabalhadores por meio de ações afirmativas, políticas de incentivo fiscais, intervenção no mercado de trabalho, modalidades contratuais inovadoras e ações características do Estado de bem-estar social.

As experiências com a flexicurity não estão mais restritas, no entanto, à União Europeia ou ao continente europeu como um todo, tendo iniciado sua propagação para outros pontos do mundo capitalista. Merece menção a busca pela "flexsegurança" no Japão. Kazutoshi Chatani aduz que o modelo japonês era baseado em um forte compromisso, ainda que tácito, pela manutenção de contratos de trabalho de longa duração para empregados clássicos, mas do sexo masculino. De tal forma, a segurança dos trabalhadores era decorrente da própria estrutura do mercado de trabalho fundamentada em relações de emprego estáveis. No entanto, frisa o autor, houve uma mudança de cenário na realidade japonesa, com o ${ }^{130}$ No original: "some actual applications of this concept of flexicurity outside Denmark are in France, where 36month specific-purpose 'mission contracts' have been introduced. At the end of the contract, depending on need and performance, a firm decides whether to convert the contract to an open-ended one. This provides the firm with more flexibility especially in dealing with shocks such as greater import competition. Also in France, the national public employment service agency has been placed in charge of unemployment insurance. That has made possible better monitoring and at the same time better services. In addition, the vocational training system is being reformed to aid better adjustment. MITRA, Devashish; RANJAN, Priya. "Social protection in labour markets exposed to external shocks". in BACCHETTA, Marc; JANSEN, Marion (coord.). Making Globalization Socially Sustainable. Genebra: OIT, 2011. Disponível em http://www.ilo.org/wcmsp5/groups/public/--dgreports/---dcomm/---publ/documents/publication/wcms 144904.pdf (último acesso em 30/12/2012), pág. 223. 
crescimento da utilização de modos de trabalho "não-regulares", (não se trata de trabalho ilícito, mas de formas atípicas de labor), colocando em crise o sistema de "segurançacorporativo" que dependia fundamentalmente do contrato estável vinculado a uma única corporação, deixando uma parcela grande de trabalhadores relativamente desprotegidos. A solução passou a ser buscada, aduz o professor citado, na mudança para um sistema próprio de flexicurity. ${ }^{131}$ ",

O autor prossegue a análise afirmando que o governo japonês, por si só, não ofereceu alternativas adequadas para a segurança dos trabalhadores, mas que isso pode ser atingido por medidas conjuntas entre governo e parceiros sociais, com discussões e redefinições da segurança para o mercado de trabalho, com utilização de instrumentos e recursos já existentes na sociedade. Em contraponto à tradicional "mão-invisível" do mercado idealizada por Adam Smith, o professor Chatani ressalta a necessidade de uma "mão-vísivel", com políticas que possam coordenar esforços do governo com seus parceiros sociais para atingir os objetivos da flexicurity, com o necessário e almejado equilíbrio entre a flexibilidade do mercado de trabalho e a segurança dos trabalhadores ${ }^{132}$.

O supracitado autor italiano Marino Regino lembra que as experiências holandesa, sueca e dinamarquesa com a flexibilização ampla foi possível com o uso de políticas ativas de trabalho e de um sólido sistema de proteção social, diferentemente do que aconteceu com

\footnotetext{
${ }^{131}$ No texto original, são as seguintes as palavras do autor: "Japanese companies used to demonstrate a tacit but strong commitment to long-term employment for (male) regular employees. Indeed, security on the labour market was concomitant to the continuous practice of stable employment relationships. Stable employment, however, came under increasing market pressure. The increase in the share of non-regular workers has engendered tensions in the traditional corporate-centred approach to security as it left a large proportion of workers relatively unprotected". CHATANI, Kazutoshi. From corporate-centred security to flexicurity in Japan. Genebra: OIT, 2008. Disponível em http://www.ilo.org/public/english/employment/download/wpaper/wp17.pdf (último acesso em 28/12/2012).

${ }^{132}$ No texto original: "If the government alone cannot meet the increasing demand for a new type of labour market security, then it seems vital that the government, together with social partners, discusses, re-designs and implements the new labour market security, by mobilizing the instruments and resources of the society. Since market mechanisms alone cannot strike a desirable balance between security and flexibility, a 'visible hand', shaped by the well-coordinated efforts of the government and social partners, is required". CHATANI, Kazutoshi. op. cit.
} 
Inglaterra e Irlanda, onde se desenvolveu apenas uma ampla desregulamentação do mercado de trabalho, com nítido prejuízo ao bem-estar do trabalhador. ${ }^{133}$

É cabível retomar o tema, ainda, de que a proteção do trabalhador no âmbito da flexicurity deixa de ser voltada ao emprego de longa duração na mesma empresa e passa a ser vinculada à busca da manutenção da empregabilidade, como forma de adaptar o trabalhador ao dinamismo característico do moderno processo produtivo. Nesse sentido, afirma Peter Auer que "a novidade na presente mudança parece estar, portanto, além da tradicional forma de segurança no emprego. Está surgindo uma nova forma combinada de segurança (algum grau de segurança no emprego vinculada a (diversas) empresas, convivendo com proteção social frequentemente na forma de políticas de mercado de trabalho (fora das empresas) - que cobre ao mesmo tempo (alguma) segurança no emprego e segurança nas transições entre empregos. Essa mudança deveria então ser chamada de 'segurança no trabalho' para segurança do mercado de trabalho' ao invés de 'segurança no trabalho' para 'segurança na empregabilidade ${ }^{\prime \prime 134}$. (tradução livre).

Analisado o conceito de flexicurity, sua evolução e aplicabilidade nos locais de nascimento, em especial, como visto, a União Europeia e Escandinávia, é necessário estudar a possibilidade de aplicação do instituto à realidade brasileira, objeto direto da presente tese.

\footnotetext{
${ }^{133}$ No original: "In Olanda, Danimarca e Svezia, la flessibilizzazione del mercato del lavoro è avvenuta in modo altrettanto generalizzato, ma nel quadro di un sistema di tutele di welfare che non è stato radicalmente ridimensionato. Mentre nei due paesi insulari (Inglaterra e Reino Unido) si tratta di una flessibilità senza rete, in questi paesi dell'Europa del nord la flessibilità è resa possibile dal funzionamento di politiche attive del lavoro e dalla solidità del sistema di protezione sociale". (texto em negrito inserido pelo autor da tese). REGINO, Mario. op. cit., pág. 4.

${ }^{134}$ No original: "The novelty in the present shift seems therefore to be one beyond the traditional form of employment security: emerging is a new combined security (some degree of employment security within (several) firms going together with social protection - often in the form of labour market policies - outside the firms) which covers both (some) employment security and security in transitions. This shift should then rather be called from job to labour market security than from job to employment security." AUER, Peter. Security in labour markets:Combining flexibility with security for decent work. Genebra: OIT, 2007, pág. 4. Disponível em http://www.ilo.org/wcmsp5/groups/public/---ed_emp/---emp_elm/---analysis/documents/publication/wcms
}

113923.pdf (último acesso em 28/12/2012). 
Em primeiro lugar deve ser verificado se há espaço no atual cenário político-social do país para a implementação da flexicurity. Não se nega que a crise econômica global atingiu o país, ainda que em menor escala se comparada com outras realidades. Não se nega, ainda, que a necessidade de proteção do emprego e da empregabilidade é cada vez maior. A insegurança no trabalho, com a dúvida a respeito das possibilidades de manutenção das necessidades básicas do indivíduo e da família é um ponto de preocupação de todo o trabalhador, sem constituir o brasileiro exceção. A estabilidade, senão no mesmo emprego, mas ao menos financeira por saber-se, ainda que em período sem trabalho, que a recolocação em novo posto se dará em tempo razoável, é um anseio de todo ser humano que trabalha. A economia, representada pelos detentores do capital, brada pela necessidade crescente de maior flexibilidade do mercado de trabalho. Assim, desde que possível, é certo que há espaço para o desenvolvimento da "flexisegurança" na realidade brasileira.

Em segundo lugar, considerando-se que a flexicurity abrange diversos critérios políticos e econômicos e considerando-se que a presente tese não tem por escopo o aprofundamento em tais áreas da ciência, é imprescindível estudar a viabilidade da "flexisegurança" sob o ponto de vista jurídico, sobretudo no que diz respeito a medidas de direito positivo, ainda que dependam de profunda e estrutural reforma legislativa.

A resposta inicial e que seria natural ao questionamento acima, da aplicabilidade direta dos conceitos estudados no presente capítulo à realidade brasileira, ainda que haja o desejo por ambos os elementos envolvidos, é negativa. Com efeito, critica-se que é abismal a diferença na organização sócio-política-econômica entre o Brasil e a Dinamarca, berço da chamada flexicurity. No entanto, não se nega que a diferença em questão seja grande e que são necessárias diversas adaptações, mas a discrepância de elementos externos ao conceito não elimina totalmente sua aplicabilidade.

Ademais, pode-se argumentar que as diferenças sócio-político-econômicas entre Brasil e Dinamarca não são tão maiores do que as diferenças de mesma origem entre os países Escandinavos e os países da Europa Mediterrânea que também buscam a aplicação, em maior ou menor grau e com maior ou menor sucesso da flexicurity, sendo que muitos desses países estão em situação econômico-social similar ou até mesmo inferior ao Brasil. 
Em outros termos, procurar-se-á demonstrar que com as devidas adaptações podem ser utilizados na realidade brasileira, com bom grau de aproveitamento, uma série de elementos que se enquadram no conceito de flexicurity, sempre voltadas as atenções para os aspectos do direito positivo.

Ademais, pode-se notar que as respostas do governo brasileiro às necessidades da crise, já apontam para medidas de flexicurity, embora sem utilizar tal denominação. Com efeito, em estudo da Organização Internacional do Trabalho denominado "Brasil: Uma Estratégia Inovadora Alavancada pela Renda"135, destaca-se que o país tomou medidas afirmativas para enfrentar a crise com política monetária, cambial e creditícia. Afirma o relatório que o "PAC Programa de Aceleração do Crescimento" e o programa de habitação "Minha Casa Minha Vida”, impactaram na criação e manutenção de empregos, sobretudo na área da construção civil. Lembra a citada obra que o Brasil é um dos poucos países da América Latina que possui sistema de seguro-desemprego (são seis no total) e que o sistema de proteção social se funda também na distribuição de renda, como no programa da "Bolsa Família". Por fim, o relatório indica, ainda, que também medidas de flexibilização foram oferecidas para o combate à crise, como a possibilidade de flexibilização de jornada por meio de negociação coletiva, o que de fato chegou a ocorrer com algumas empresas do ramo automotivo. ${ }^{136}$

No tocante à faceta da flexibilização, faz-se necessário um destaque relativo ao direito brasileiro. Como visto no presente capítulo, a principal preocupação com a flexibilização no direito europeu vinculada à flexicurity diz respeito à facilitação da dispensa do trabalhador de modo a tornar menos rígido o mercado de trabalho. Ocorre que tal mudança no Brasil deve ser acompanhada de outros estudos, pois é sabido, como já apontado, que vigora no direito pátrio a dispensa sem justa causa como direto potestativo do empregador, sendo o disposto no artigo $7^{\circ}$, inciso I da Constituição Federal norma constitucional de eficácia limitada (sobre a eficácia das normas constitucionais, verificar capítulo anterior dessa tese). Assim, nos termos da legislação vigente o mercado de trabalho brasileiro não é rígido sob o ponto de vista das limitações à dispensa do trabalhador, frisando-se que o acréscimo de $40 \%$ sobre os depósitos

${ }^{135}$ ORGANIZAÇÃO INTERNACIONAL DO TRABALHO, Instituto Internacional de Estudos do Trabalho. Brasil: uma Estratégia Inovadora Alavancada pela Renda. Genebra: OIT, 2011.

${ }^{136}$ ORGANIZAÇÃO INTERNACIONAL DO TRABALHO. op. cit., págs. 49/83. 
do FGTS e a concessão de aviso prévio proporcional ao tempo de serviço são medidas praticamente inócuas se comparadas às limitações impostas aos signatários da Convenção $\mathrm{n}^{\circ}$ 158 da Organização Internacional do Trabalho.

Deve-se destacar, no entanto, que a liberdade de dispensa no direito brasileiro vem sendo questionada, em especial no que diz respeito à limitações jurisprudenciais para a chamada dispensa coletiva. Nesse cenário, é importante que a adoção de medidas voltadas para a flexicurity, mesmo na realidade brasileira, observem padrões a serem seguidos para a regulamentação da dispensa coletiva, quando estritamente necessária.

O principal elemento de flexibilização, constituído na facilidade de dispensa, já existe, portanto, no direito brasileiro. A criação de medidas de fomento a contratação é possível e cabível no país, com introdução de tipologias contratuais flexíveis como as já existentes em outros países, conforme já destacado no capítulo sobre a flexibilização.

Medidas de "welfare state" de subsídio ao trabalhador desempregado, incentivos à recolocação no mercado e formação do trabalhador também podem e devem ser implementados no direito brasileiro. As ações afirmativas de intervenção no mercado de trabalho também são plenamente possíveis, algumas até já implementadas, como destacado acima.

Assim, a conclusão é de que a situação de desenvolvimento atual do país propicia a implantação de pontos de flexicurity e de que tais medidas podem contribuir para a mitigação da crise econômica, com criação e manutenção de postos de trabalho e empregabilidade.

Especificamente no que diz respeito ao objeto do presente estudo, a solução da crise jurídica do Direito do Trabalho e a proteção do trabalhador em detrimento da proteção unicamente do empregado, pode-se afirmar que medidas de "flexisegurança" detém potencial de contribuição para a melhoria das condições de proteção ao trabalhador em sentido amplo.

Nesse sentido, e essencial a lembrança de que a adaptação ao direito brasileiro de medidas de flexicurity não pode ignorar a existência de direitos fundamentais do trabalhador, com respeito às implicações decorrentes da existência de uma teoria específica dos direitos fundamentais e sua aplicabilidade, como a impossibilidade de retrocesso analisada no capítulo próprio. Sobre situação similar no direito europeu, Massimiliano Delfino afirma que de acordo com os resultados das consultas públicas a respeito do "Livro Verde", muitos dos atores 
interessados (estados-membros, sindicatos, acadêmicos) efeturaram críticas quanto à subvalorização do tema dos direitos fundamentais indicado que "a reforma do Direito do Trabalho deve ser inserida, desde o inicio, no quadro representado pelos direitos fundamentais, em particular os da Cara de Direitos Fundamentais da União Europeia. ${ }^{137 \text { ” }}$

Ao se procurar desenvolver um modelo específico para a aplicação da flexicurity, devese ter em mente, ainda, o alerta do supracitado autor Peter Auer de que "de fato, todos os aparentes paradoxos (da combinação de flexibilidade com segurança) poderem ser resolvidos ao se desenvolver inteligentemente reformas do mercado de trabalho que levem em consideração as necessidades de estabilidade, flexibilidade e segurança, o que deve ser o caso para todos os conceitos da flexicurity. Omitir um desses elementos - e também o diálogo social no processo - irá produzir resultados sub-ótimos ou para a produtividade, ou para a empregabilidade ou para a segurança dos trabalhadores. ${ }^{138 "}$ " (texto em negrito inserido pelo autor da tese).

Com efeito, a "flexisegurança" pode ser aplicada para se regular as diversas formas de prestação pessoal de serviços de modo a atender as necessidades de flexibilização tanto dos tomadores de serviços quanto dos trabalhadores, seja por meio de contratos subordinados atípicos, seja por meio do trabalho autônomo. Essa regulamentação pode se focar, no aspecto da segurança, em princípios gerais de não discriminação e na existência de um núcleo mínimo de direitos fundamentais que atenda a toda a classe dos trabalhadores, independente da tipologia contratual adotada.

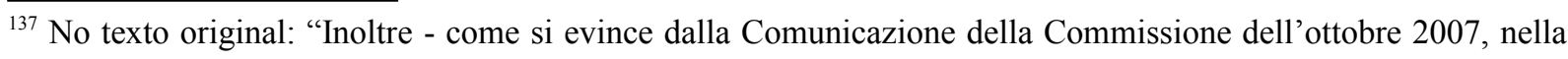
quale si dà conto dei risultati della consultazione pubblica avviata dal Libro Verde - molti attori interessati (Stati membri, sindacati, accademici) hanno avanzato critiche alla sottovalutazione del tema dei diritti fondamentali, affermando che "la riforma del diritto del lavoro dovrebbe essere inserita fin dall'inizio nel quadro rappresentato dai diritti fondamentali, in particolare dalla Carta dei diritti fondamentali dell'Unione europea" DELFINO, Massimiliano. Diritti Sociali e flexicurity. Napoli, 2008, pág.20.

${ }^{138}$ No original: "in fact all these apparent paradoxes might be solved if one intelligently designs labour market reforms that take into account the need for stability, flexibility and security, which should be the case for all concepts of flexi-curity. Omitting one of these elements - and also the social dialogue on the process side - will produce suboptimal results either for productivity, employment performance or workers security." Auer, Peter. op. cit., pág. 11.
} 
$\mathrm{O}$ aspecto de maior relevância da expansão de direitos a todos os trabalhadores por meio da flexicurity é o de que os maiores gastos gerados pelo acréscimo de direitos, reclamação constante dos tomadores de serviços, são compensados por medidas de flexibilidade e incentivo ao mercado de trabalho por meio do Estado, impactando diretamente no ganho de produtividade. Trata-se, portanto, de um intervencionismo estatal em uma relação triangular, com benefícios tanto para os trabalhadores quanto para os empregadores, em sentido amplo, e cujos custos se equilibram por meio da maior produtividade e empregabilidade que pode ser atingida.

Os resultados, por óbvio, não são garantidos. No entanto, os riscos decorrentes da maior flexibilização das formas de contratação, desde que haja a contrapartida da expansão de direitos trabalhistas a não empregados em sentido estrito e a todos os que trabalham de forma atípica, são suportáveis e reversíveis em caso de insucesso. Embora atendidos interesses econômicos, o predomínio do pensamento é e deve ser o da proteção do trabalhador. Como sustentado no presente texto, é inevitável o crescimento da prestação de serviços de forma flexível, portanto a busca deve ser para que essa flexibilização se dê com o menor impacto possível nos direitos trabalhistas e que tais direitos atinjam número cada vez maior de trabalhadores.

Considerando-se, no entanto, que a flexicurity não comporta um modelo fechado, necessária se faz a proposição de um sistema específico de flexisegurança a ser adotado no Direito Brasileiro, o que se fará em capítulo apartado. 


\section{NOVOS PARADIGMAS - EXPANSÃO DO OBJETO DO DIREITO DO TRABALHO}

Restou demonstrado nos capítulos anteriores do presente texto que a mudança na forma de prestação do trabalho humano por conta das crises econômicas implica em uma incontestável crise do próprio Direito do Trabalho. Com efeito, o conjunto de normas e princípios destinados a regular a prestação de trabalho subordinado não é mais suficiente para conferir a proteção jurídica a todos os que dependem do trabalho para a sobrevivência digna, em face da crescente demanda de prestação de serviços de modo flexível, autônoma ou parassubordinada.

A reforma do Direito do Trabalho deve ser tratada tendo em vista a condição de valor fundamental do trabalho humano e a necessidade de regulamentação das relações entre o homem que trabalha e o tomador dos serviços, em sentido amplo. A reflexão pode ser feita com base nas palavras de Amauri Mascaro Nascimento para quem "o trabalho, no mundo moderno, é um valor fundamental, sofre o impacto direto dos acertos ou desacertos econômicos de um país, que se refletem sobre as relações de trabalho, favorecendo-as ou penalizado. O direito do trabalho é expressão do humanismo jurídico e arma de renovação social pela sua total identificação com as necessidades e aspirações concretas do grupo social diante dos problemas da questão social. Representa uma atitude de intervenção jurídica, para a restauração das instituições sociais e para melhor relacionamento entre o homem que trabalha e aqueles para os quais o trabalho é destinado. ${ }^{139}$ ",

Nesse diapasão, considerando que o Direito do Trabalho é a ferramenta mais poderosa para concretizar a dignidade da classe trabalhadora, no sentido de todos aqueles que trabalham para a atividade produtiva alheia, é que se faz necessária a expansão do objeto do ramo juslaboral.

Desse modo, a necessidade de expansão do objeto do Direito do Trabalho defendida nessa tese parte de duas premissas básicas que serão explanadas a seguir.

\footnotetext{
${ }^{139}$ NASCIMENTO, Amauri Mascaro. "Mudanças no Mercado de Trabalho”. in RODRIGUES, Aluisio, (coord.). Direito Constitucional do Trabalho. São Paulo: LTR, 1993, pág. 35.
} 
A primeira delas é a de que a prestação de serviços por modos distintos do contrato de trabalho clássico e rígido envolvendo o empregado subordinado é uma necessidade inquestionável e insuperável. São inadequadas e inócuas medidas e até mesmo decisões judiciais que procurem reduzir toda forma de trabalho humano à categoria da relação de emprego. Do mesmo modo, inadequada a separação bipolar de empregado e trabalhador autônomo, o primeiro com forte apoio do direito estatal e heterônomo e o segundo sem qualquer tipo de proteção jurídica. As transformações sócio-econômicas descritas no texto alteraram a forma da distribuição do trabalho humano e essa mudança não pode ser ignorada, evitada ou revertida por meio de legislação ou decisões judiciais que pretendam enquadrar em determinada categoria algo que não lhe pertence.

A reforma italiana optou pela flexibilização trabalhista, multiplicando as modalidades contratuais dentro do próprio conceito de trabalho subordinado. Segundo Giuseppe SantoroPassareli, o objetivo da diversificação foi adequar, quase sempre, a duração temporária dos contratos, facilitando a dispensa do empregado. ${ }^{140}$ Como visto anteriormente, o direito brasileiro não é rígido na forma de dispensa dos empregados, sendo que as medidas de flexibilização devem visar a expansão da proteção jurídica, com regulamentação de outras formas de trabalho além da subordinada. A multiplicidade contratual dentro do tipo "subordinação" pode ser útil em parte, mas não irá resolver os problemas envolvendo o grande número de trabalhadores que prestam serviços sem subordinação no sentido clássico.

Nesse diapasão, criticando a própria reforma italiana, Luisa Galantino alerta que as novas figuras contratuais e a releitura de figuras já existentes não alteraram o tradicional divisor de águas centrado no binômio autonomia-subordinação ${ }^{141}$. De tal forma, as alterações

\footnotetext{
${ }^{140}$ Afirma o professor italiano que: "non si può comunque fare a meno di osservare che la diversificazione dele tutele nell 'ambito del lavoro subordinato mira a realizzare, quasi sempre, la temporaneità del vincolo obbligatorio perseguendo una strategia di aggiramento della maggiore regidità normative del raporto di lavoro, e cioè la limitazione del potere di recesso del datore di lavoro". SANTORO-PASSARELLI, Giuseppe. "Flessibilità e Rapporti di Lavoro". in SANTORO-PASSARELLI, Giuseppe (coord). Flessibilità e Diritto del Lavoro. v. III, Torino: G. Giappichelli, 1997, pág. 19.

${ }^{141}$ No original: "L'elaborazione di nuove figure contrattuali e la rilettura di quelle preesistenti non hanno inciso sul tradizionale spartiacque qualificatorio posto dal binomio autonomia-subordinazione. GALANTINO, Luisa. "La Finalità della Riforma". in GALANTINO, Luisa (coord). La Riforma del Mercato del Lavoro. Torino: G. Giappichelli, 2004, pág. 12.
} 
italianas foram insuficientes para atingir a fórmula "more jobs e better jobs" lembrada pela mesma professora ${ }^{142}$.

A segunda premissa para o desenvolvimento da tese é a de que toda forma de trabalho humano necessita de alguma proteção jurídica, ainda que possa haver diferenciação de grau e diversificação de normas. O trabalho é elemento essencial da inserção do ser humano na realidade econômica. É o meio de garantia do sustento da maior parte da população e deve ser valorizado como Direito Fundamental. Como demonstrado anteriormente, o trabalhador que nos tempos atuais não se insere no conceito de empregado não é necessariamente, e a melhor dizer, nem mesmo na maior parte das vezes, autosuficiente ou capaz de atuar com igualdade de condições nas contratações entre capital e trabalho.

Maria Marta Vieira dos Santos aduz, por exemplo que "nas relações jurídicas provenientes de uma relação de trabalho, na maioria dos casos, o trabalhador não fica subordinado econômica e juridicamente ao tomador dos seus serviços, tendo esse tipo de trabalhador maior autonomia para convencionar e impor as cláusulas desse contrato, o que os difere dos autênticos empregados" $" 143$. Com o devido respeito ao posicionamento da autora, pouco ou nenhum poder de negociação tem o trabalhador que se insere em atividade produtiva alheia, ainda que o trabalho não se de na forma de uma relação de emprego. Tais trabalhadores continuam a ser, salvo melhor juízo, hipossuficientes na relação contratual.

Assim, conclui-se que toda forma de trabalho deve ser tutelada pelo Direito do Trabalho, em maior ou menor grau, propondo-se a mudança de paradigma do ramo juslaboral.

Como dito, o fato de direcionar a prestação de serviços à atividade econômica de outrem, de colocar sua força de trabalho como meio de produção de um terceiro, implica, em maior ou menor grau, em dependência econômica e de tal modo implica na necessária proteção jurídica para se evitar o aviltamento do "valor-trabalho". Com efeito, ainda que autônomo, o serviço direcionado à atividade produtiva alheia é desse dependente, mesmo que não se possa falar em subordinação jurídica capaz de levar ao reconhecimento do vínculo de emprego.

\footnotetext{
${ }^{142}$ GALANTINO, Luisa. op. cit., pág. 3.

${ }^{143}$ SANTOS, Maria Marta Vieira dos. "O Princípio Protetor Frente À Nova Competência Da Justiça Do Trabalho". in Juris Sintese, no 54, julho/agosto de 2005.
} 
Em fundamentado estudo aponta Paulo Gustavo Amarante Merçon que "a partir do momento em que o trabalhador aliena seu trabalho a alguém que detenha uma organização produtiva, o trabalho, no âmago da relação jurídica, passa a ser hipossuficiente, configurandose a relação de trabalho. É o caso do médico que trabalha para uma clínica, ainda que de forma eventual ou não-subordinada." $" 144$

Sobre a necessária proteção do trabalhador em face das alterações do processo produtivo, é correta a premissa adotada por Cláudio Armando Couce de Menezes ao afirmar que "destarte, em que pese o processo produtivo e as relações trabalhistas não se prenderem mais ao modelo arcaico denunciado por ZOLA no "Germinal", tampouco aquele, típico da modernidade, do regime taylorista e fordista, tratado com tanta graça e perspicácia por Chaplin em "Tempos Modernos", as novas formas em curso mantêm, contudo, o domínio do empregado e o seu controle da prestação dos serviços, quando não da própria pessoa do trabalhador. Essas novas medidas apelam para a precarização do trabalho, preservando, com novas roupas, práticas remotas de exploração. Por isso, permanece a necessidade de limitação da jornada, estipulação de períodos de repousos, inclusive anuais, estabelecimento de meios para assegurar o emprego ou uma compensação substancial pela sua perda, edição de normas de higiene, fixação de um salário mínimo etc. ${ }^{145 ",}$

Não se concorda, contudo, com a conclusão e solução proposta pelo autor que é a do alargamento dos meios de caracterização da relação de emprego. Com efeito, defende-se no texto a necessidade de proteção do trabalhador em face das novas formas de trabalho, mas isso não quer dizer que se deve chamar de "emprego" uma relação que não o é, tampouco conferir direitos específicos de um contrato típico de emprego a uma forma de contratação atípica. A proteção deve ser conferida, mas deve ser especifica para cada modo de trabalho.

\footnotetext{
${ }^{144}$ MERÇON, Paulo Gustavo de Amarante. "Direito do Trabalho Novo". in Revista LTR, ano 75, v. 01, 2011, pág. 86.

${ }^{145}$ MENEZES, Claudio Armando Couce. "Os Novos Contornos das Relações de Trabalho e de Emprego - Direito do Trabalho e a Nova Competência Trabalhista Estabelecida pela Emenda $n^{\circ} 45 / 04$ ". in Juris Sintese, $n^{\circ}$ 56, outubro/novembro de 2005.
} 
A abordagem expansionista do Direito do Trabalho, ou ao menos o reconhecimento da existência da crise do Direito do Trabalho e a necessária releitura de seus conceitos clássicos, vem sendo identificada pela doutrina nacional e estrangeira já há algum tempo.

Com efeito, já lecionava Amauri Mascaro Nascimento há mais de uma década que "a diversificação dos temas centrais do direito do trabalho e das relações de trabalho em um novo quadro socioeconômico, no qual se combinam elementos de flexibilização e intervencionismo diante da fragmentação do mercado de trabalho e da redução de empregos, caracterizam a época pela retipificação dos contratos de trabalho." 146

Irany Ferrari, também em obra com primeira edição em 1998, ao tratar de tendências para um futuro do Direito do Trabalho, afirmava que "o contrato de emprego está se desfigurando. Apregoa-s, então, o contrato de atividade, para a proteção do trabalho e não mais do emprego." 147

A lição de Massimo D’Antona expressa em texto supracitado também é no sentido de que o Direito do Trabalho moderno deve percorrer a via inversa da especialização inicial, em que o foco foi transferido para o trabalho subordinado, passando a preocupar-se com todos os tipos de trabalho, subordinado ou autônomo. Frisa o autor que o Direito do Trabalho deve ocupar-se de todas as múltiplas formas disponíveis de contratação de trabalho existentes na organização produtiva moderna que é muito menos rígida. O foco, prossegue o professor italiano, deve ser o trabalho pessoal na organização produtiva de outrem e não a forma como o trabalho é contratado. ${ }^{148}$

Mesmo a flexibilização, que como visto anteriormente é tida como contraposta a pretensões expansionistas do Direito do Trabalho, pode ser vista como modo de estímulo

\footnotetext{
${ }^{146}$ NASCIMENTO, Amauri Mascaro. Curso de Direito do Trabalho. 16 ${ }^{\mathrm{a}}$ ed., São Paulo: Saraiva, 1999, pág. 49.

${ }^{147}$ FERRARI, Irany. "O Trabalho em Tempos Futuros". in FERRARI, Irany; MARTINS FILHO, Ives Gandra; NASCIMENTO, Amauri Mascaro, (coords.). História do Trabalho, do Direito do Trabalho e da Justiça do

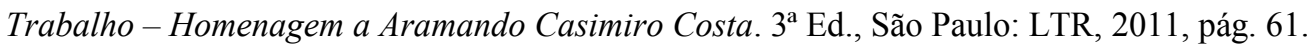

${ }^{148}$ Nas palavras do autor: "Ora quella totale identificazione con la figura sociale tipica declina, e il diritto del lavoro sembra percorrere a ritorso la strada che va dal lavoro (subordinato tipico) ai lavori (subordinati o autonomi), che vuol dire tornare a occuparsi dell intera gamma dei contratti mediante i quali si realizza, nelle molteplici forme consentite da una organizzazione produttiva oggi assai meno rígida del passato, l'integrazione del lavoro prevalentemente personale nell ‘attività economica altrui.” D`ANTONA, Massimo. op. cit., pág. 322.
} 
protetivo aos anteriormente inseridos na economia informal. Tratando da reforma italiana, Sergio Corbascio e Onofrio Nacci afirmam que um dos intuitos dos legisladores que trataram da reforma foi justamente de adaptar velhos conceitos juslaborais, trazendo maior flexibilidade para os contratos, com a contrapartida de formalização de contratos antes informais, protegendo pessoas que anteriormente não gozavam de qualquer apoio do Direito do Trabalho. ${ }^{149} \mathrm{Ou}$ seja, até mesmo os defensores da flexibilização juslaboral reconhecem a necessidade de proteção de um maior número de trabalhadores.

O novo Direito do Trabalho não perderá seu caráter humanístico. É evidente que o ramo da ciência juslaboral permanecerá focado no ser humano que trabalha e em suas necessidades. No entanto, é certo que o Direito do Trabalho integra um sistema jurídico que por sua vez regula uma realidade jurídico-política-econômica-social. Não existe Direito do Trabalho sem relação produtiva. Na realidade, se inexistente o capitalismo, não haveria nem mesmo objeto para o Direito do Trabalho. Assim, a ciência juslaboral não pode ignorar a realidade econômica, devendo se desenvolver juntamente com essa, buscando sempre o equilíbrio e evitando a sobreposição de interesses.

Maurício Godinho Delgado reconhece um desgaste ideológico do Direito do Trabalho e aponta que a retomada do expansionismo do Direito do Trabalho é necessária "como política pública de inclusão social, econômica e até mesmo cultural nos marcos da sociedade capitalista". Indica que esse expansionismo pode se dar por três caminhos: o primeiro "a crescente e contínua busca de efetividade do próprio Direito do Trabalho, aplicando-se realmente o ramo jurídico às relações socieconômicas que lhe são específicas". O segundo "a própria ampliação do conceito de relação de emprego - cardeal ao Direito do Trabalho -, atualizando-o de modo a incorporar novas facetas da prestação laborativa por pessoas físicas no país.”. Finalmente "a extensão do Direito do Trabalho a relações de trabalho, ultrapassando o marco clássico da simples relação de emprego" ${ }^{150}$.

\footnotetext{
${ }^{149}$ Segundo os autores: "Appare chiaro l'intento del legislatore di determinare condizioni di trasparenze del mercato, nella dichiarata volontà di trasformare i vecchi assetti giuslavoristici, finalizzandoli ad una maggiore flessibilità ed al contempo prevedendo tutele per coloro che nel passato regime normativo non ne possedevano alcuna". CORBASCIO, Sergio; NACCI, Onofrio. "Riforma de Mercato del Lavoro e Contrasto al Lavoro Nero". in TIRABOSCHI, Michele (coord). La Riforma Biagi del Mercato del Lavoro. Milano: Giuffrè, 2004, pág. 251.
} 
Otávio Pinto e Silva ensina que "o critério usado para a construção de um sistema de proteção social ao trabalhador foi o da subordinação, como elemento indispensável para a configuração da relação de emprego". Em seguida analisa o autor estatísticas decrescentes da utilização do labor de empregados e a crescente precarização das relações de trabalho. Prossegue afirmando que: "essa realidade provoca, então, uma necessária reflexão sobre a inocuidade de um sistema de proteção social que deixa uma ponderável parcela do mercado de trabalho à sua margem". Após propor um novo estudo da subordinação, autonomia e da parassubordinação, conclui o autor pela necessidade da "revisão do âmbito pessoal do direito individual do trabalho, a fim de que passe a abranger todas as formas de relação de trabalho (subordinado, autônomo, parassubordinado)."151

No mesmo sentido, ressaltando a necessidade de proteção de trabalhadores "semidependentes" por se inserirem na atividade produtiva alheia, Thereza Christina Nahas afirma que "a questão que deveria se colocar não nos parece que seja a necessidade ou não de se enumerar num artigo de lei ordinária quais os tipos contratuais que seriam conhecidos e julgados pelo legislador trabalhista. A questão é mais funda, pois refere-se a ter conhecimento da extensão dos direitos trabalhistas a outros trabalhadores que não são, necessariamente, subordinados no sentido que a CLT imprimiu, em 1943, a este tipo de prestador de serviços, e que teve por objetivo the conferir um tratamento diferenciado e tutelar do modelo previsto no Código Civil. Todavia, diante da dependência econômica que possuem com o seu tomador de serviços, merecem a proteção e a tutela jurídica laboral, universo esse muito mais abrangente e, até aqui, ignorado pela maior parte dos operadores do direito do trabalho em todos os seus níveis." 152

Gabriela Neves Delgado alerta que "as relações de trabalho que formalmente não se encontram hoje regidas pelo Direito do Trabalho também precisam ser reconhecidas como

\footnotetext{
${ }^{150}$ DELGADO, Mauricio Godinho; DELGADO, Gabriela Neves. Constituição da República e Direitos Fundamentais - Dignidade da Pessoa Humana, Justiça Social e Direito do Trabalho. São Paulo: LTR, 2012 (versão digital), págs. 111/112.

${ }^{151}$ SILVA, Otávio Pinto e. Subordinação, Autonomia e Parassubordinação nas Relações de Trabalho. São Paulo: LTR, 2004, págs. 2/3 (versão digital).
} 
objeto de efetiva tutela jurídica, para que o trabalhador que as exerça possa, por meio da proteção jurídica, alcançar o espaço para o exercício de seus direitos. ${ }^{153 "}$

A alteração da competência da Justiça do Trabalho efetuada pela Emenda Constitucional $n^{\circ}$ 45/04 ampliou o campo de atuação desse ramo especializado do Poder Judiciário. No entanto, tal mudança não impactou a esfera do direito material, continuando as relações de trabalho que não a de emprego fora da cobertura do manto do Direito do Trabalho. Destacam Maurício Godinho Delgado e Gabriela Neves Delgado que "maturada a interpretação acerca do sentido do novo inciso I do art. 114 da Constituição (relação de trabalho e não relação de emprego: EC 45/2004), tem prevalecido o entendimento de que houve, de fato, significativa ampliação da competência judicial trabalhista - embora sem

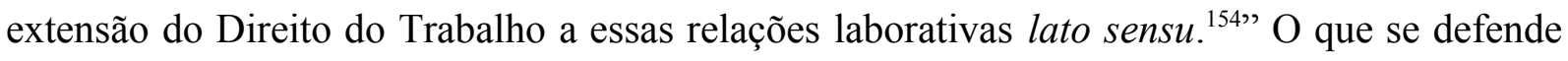
nessa tese é que essa extensão não impactará de modo negativo as relações de emprego, tampouco irá descaracterizar outras formas de trabalho, como o atuônomo.

Com efeito, a maior proteção de outras categorias de trabalho não retirará o foco protetivo da relação de emprego, visto que as normas que regulam essa relação não são, de todo modo, incompatíveis com as normas que são propostas. Conferir mais direitos a outros trabalhadores não corresponde, de modo algum, a suprimir direitos de empregados. Também não há que se falar em subversão dos princípios que regem o Direito do Trabalho, já que o escopo de proteção do ser humano que trabalha continuará a nortear toda a produção e aplicação normativa justrabalhista.

Quanto à limitação que se imporá a outras formas contratuais, inclusive a autônoma, não é demais lembrar que toda forma de autonomia de vontade no direito pátrio já é limitada, de maneira mais ou menos intensa, pelo princípio geral da função social do contrato. Nesse sentido a lição de Guilherme Guimarães Feliciano de que "o art. 421 do NCC (novo Código Civi) dispõe, ainda, que a autonomia privada - que também é, por si mesma, emanação do princípio constitucional da dignidade humana (art. $1^{\circ}$, III, da CF) - tem, na função social do contrato, não apenas um limite, mas também um foco: deve ser exercida em razão dessa ${ }^{152}$ NAHAS, Thereza Christina. op. cit. (versão digital).

${ }^{153}$ DELGADO, Gabriela Neves. Direito Fundamental ao Trabalho Digno. São Paulo: LTR, 2006, pág. 228.

${ }^{154}$ DELGADO, Mauricio Godinho; DELGADO, Gabriela Neves. “A Clt Aos 65 Anos: Avaliação Jurídica e Sociocultural". in Juris Sintese, n 77 , maio/junho de 2009. (versão digital). 


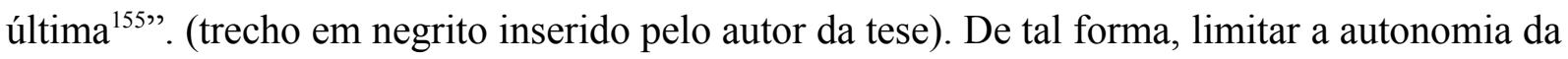
vontade nas relações contratuais trabalhistas latu sensu não constitui violação da liberdade individual, mas sim a busca do equilíbrio das relações jurídicas e a promoção do bem maior da dignidade humana.

A mudança de paradigma, prevendo a expansão do Direito do Trabalho, deve ter em vista, como ressaltado anteriormente, que o Direito do Trabalho é a principal ferramenta disponível ao trabalhador para a efetivação do fundamento constitucional da dignidade humana. Como recorda Francisco Rossal de Araújo: “é possível que as fórmulas tradicionais do Direito do Trabalho sejam inadequadas para enfrentar os novos tempos e as rápidas mudanças experimentadas no mundo capitalista e, por conseqüência, no mundo do trabalho. Defender a dignidade do trabalho humano e ter o ser humano como centro de toda a atividade jurídica não significa manter uma posição conservadora de leis ultrapassadas ou ser avesso às mudanças por simples comodismo. O debate sempre estimula e o que é novo só pode surgir da relação que permita o confronto das idéias. É preciso mudar pensando em melhorar. Mudar por mudar não significa que o novo sempre é o melhor. Uma mudança, para chegar a bom termo, precisa de um rumo, ainda que o destino final não seja totalmente conhecido ${ }^{156 "}$. A mudança assim, deve ser de tal modo que permita adequar o Direito do Trabalho à realidade assegurando aos trabalhadores a persecução da dignidade humana.

\footnotetext{
${ }^{155}$ FELICIANO, Guilherme Guimarães. "Direito do Trabalho e Direito dos Contratos: Apontamentos Relevantes Sobre a Parte Especial do Novo Código Civil (Lei no 10.406, de 10.01.2002)". in Síntese Trabalhista, n 168 , junho de 2003, pág. 25. (versão digital).

${ }^{156}$ ARAUJO, Francisco Rossal de. "O Direito do Trabalho e o Ser Humano". in Sintese Trabalhista. no 114, dezembro de 1998, pág. 15. (versão digital).
} 


\section{CARACTERÍSTICAS COMUNS DO TRABALHO HUMANO}

Antes de sugerir um núcleo essencial de direitos que possam ser aplicados a todos os trabalhadores, é importante tecer algumas considerações a respeito das características que são comuns em todas as formas de trabalho humano.

Como já destacado anteriormente, o surgimento do Direito do Trabalho e seu desenvolvimento em face do trabalho subordinado não quer dizer que essa é a única forma de atividade humana a demandar proteção, tampouco que suas características básicas sejam totalmente incompatíveis com outros modos de trabalho. Há, sim, peculiaridades em cada modalidade de prestação de serviços, caso contrário se trataria de uma única categoria. No entanto, há características que são comuns e que fundamentam a necessidade ampla da proteção jurídica do trabalho, como se verá nos itens a seguir.

Não se tratará aqui em profundidade da etimologia da palavra "trabalho", ligada ao termo latino "tripalium", espécie de instrumento de tortura e que leva à associação, portanto, do trabalho com sofrimento. Parte-se do conceito de trabalho como valor humano, conforme recorda Guilherme Guimarães Feliciano ao afirmar que "em uma síntese contemporânea, dirse-á que o trabalho consiste em uma transformação ou assimilação da natureza. (...) Diz com a necessidade daquilo que a natureza não produz espontaneamente, compreendendo-se no 'sistema de necessidades` hegeliano. Mas o trabalho não se resume à necessidade; se assim fosse, ao trabalhador bastaria o arquétipo do animal laborans, dispensado-se a liberdade. Mas há 'necessidades espirituais de representação' que se determinam pelo seu momento social. São necessidades culturais, que afinal representam a passagem da natureza à cultura (e do animal laborans ao homo faber). Trabalhamos - também - porque os outros trabalham. (...) No trabalho, o himem constrói a si mesmo, como homem objetivo, verdadeiro porque real. ${ }^{157,}$

Ao se tratar da valorização do trabalho humano ao longo do tempo e de suas características, não se pode deixar de mencionar a chamada "doutrina social da igreja". Segundo Segadas Vianna "nas diversas épocas da história, sempre os pensadores da igreja abordaram a questão social com um alto espírito de humanidade e, em todos eles, quer em Santo Agostinho, São Gregório Magno ou São Tomás, as doutrinas expostas continham

\footnotetext{
${ }^{157}$ FELICIANO, Guilherme Guimarães. Curso Crítico de Direito do Trabalho. São Paulo: Saraiva, 2012, pág. 25.
} 
valiosos ensinamentos. Se a Encíclica do Papa Leão XIII, conhecida com o nome de 'Rerum Novarum', marca o ponto culminante da participação da Igreja na solução do problema social, é certo, entretanto, que em todo o século XIX, através das figuras mais representativas, o catolicismo cuidou dos interesses do proletariado ${ }^{158}$,

O trabalho humano como valor merece a atenção da ciência jurídica a partir do momento em que se encontra, nas suas mais diversas formas, no centro da "questão social". Recorda Amauri Mascaro Nascimento que "a expressão questão social não havia sido formulada antes do século XIX, quando os efeitos do capitalismo e as condições da infraestrutura social se fizeram sentir com muita intensidade, acentuando-se um amplo empobrecimento dos trabalhadores, inclusive dos artesãos, pela insuficiência competitiva em relação à indústria que florescia. Também a agricultura sofreu o impacto da época, com os novos métodos de produção adotados em diversos países e com as oscilações de preço subsequentes. A família viu-se atingida pela mobilização da mão-de-obra feminina e dos menores pelas fábricas. Os desníveis entre classes sociais fizeram-se sentir de tal modo que o pensamento humano não relutou em afirmar a existência de uma séria perturbação ou problema social. ${ }^{159,}$

A questão social impactou, portanto, em todas as formas de trabalho. Não somente os trabalhadores subordinados, mas também os que exercem suas atividades por conta própria passaram a ser pressionados por conta das condições da relação entre capital e trabalho. A autonomia do trabalhador que desenvolve suas atividades por conta própria é apenas relativa. Via de regra, não está o trabalhador, inclusive o autônomo, dotado de ampla liberdade para contratar e fixar preços, estando sua atividade regida pelas necessidades do mercado. Ao trabalhador, inclusive o autônomo, o trabalho figura como fonte de subsistência e será desenvolvido de um modo ou de outro. Ou seja, o trabalhador necessita do trabalho para sobreviver e aceitará fazê-lo, caso necessário, em condições muito abaixo de suas pretensões contratuais para que possa receber o pagamento necessário para sua sobrevivência.

\footnotetext{
${ }^{158}$ VIANNA, José de Segadas SÜSSEKIND, Arnaldo; MARANHÃO, Délio; TEIXEIRA, João de Lima. Instituições de Direito do Trabalho. v. 1., 20ª ed., São Paulo: LTr, 2002, pág. 93.

${ }^{159}$ NASCIMENTO, Amauri Mascaro. Curso de Direito do Trabalho. 16ª ed., São Paulo: Saraiva, 1999, pág. 9.
} 
A discussão que se levanta nessa tese é aplicável, portanto, ao trabalho humano na sua forma surgida com a era industrial e nas transformações decorrentes da era pós-industrial. Em período anterior, não havia a inserção do trabalho no sistema capitalista de produção com seus efeitos direitos sobre a condição pessoal do trabalhador. Nesse sentido a lição de Maurício Godinho Delgado, com a ressalva de que também o trabalho não subordinado está submetido aos ditames do capitalismo, de que "é cientificamente desnecessária a busca de manifestações justrabalhistas em sociedades anteriores à sociedade industrial contemporânea. Nas sociedade feudais e antigas, a categoria do trabalho subordinado pode, eventualmente, ter surgido - como singular exceção -, mas jamais foi uma categoria socialmente dominante, a ponto de poder gerar um fenômeno de normatização jurídica abrangente como o Direito do Trabalho. O Direito do Trabalho é, desse modo, fenômeno típico do século XIX e das condições econômicas, sociais e jurídicas ali reunidas. ${ }^{160 "}$

O trabalho que se estuda no presente texto é, assim, parte central do sistema capitalista de produção. Salvo algumas poucas exceções, trabalho e capital estão em lados opostos da relação jurídico-social, sendo necessário que o direito intervenha para a pacificação dos conflitos e conciliação dos interesses.

Em geral, na sistemática moderna, a doutrina distingue duas grandes categorias de trabalhadores, os subordinados e os autônomos, além de outras formas atípicas como o estágio, o aprendizado e outras mais. Homero Batista Mateus da Silva apresenta a seguinte reflexão sobre as benesses de cada forma de trabalho, subordinado, ou autônomo: "quando as coisas vão mal, ser empregado representa a garantia de que os salários serão pagos, acrescidos dos 'benefícios', porque os riscos da atividade pertencem ao empregador. Quando as coisas vão bem, o empregado não consegue esconder a vontade imensa de compartilhar os lucros com o empregador ou de, pelo menos, dispor de uma remuneração móvel capaz de lhe proporcionar uma retirada maior nas épocas de colheita farta. Há, também, a questão ligada ao orgulho próprio de poder dizer 'não tenho 'patrão' quando se quer afirmar que ninguém lhe controla horários e ninguém lhe traça o destino."161

\footnotetext{
${ }^{160}$ DELGADO, Maurício Godinho. Curso de Direito do Trabalho. São Paulo: LTr, 2002, pág. 82.

${ }^{161}$ SILVA, Homero Batista Mateus da Silva. Curso de Direito do Trabalho Aplicado - Parte Geral. Rio de Janeiro: Elsevier, 2009, pág. 11.
} 
Nelson Mannrich define o trabalhador autônomo como "a pessoa natural que, habitualmente e por conta própria e mediante remuneração, exerce atividade econômica de forma independente, mediante estrutura empresarial própria, ainda que modesta."162

A definição de empregado é dada pela própria lei, dispondo o artigo $3^{\circ}$ da CLT que "considera-se empregado toda pessoa física que prestar serviços de natureza não eventual a empregador, sob a dependência deste e mediante salário".

Pode-se dizer, no entanto, que o "não ter patrão" ou o "exercer atividade econômica por conta própria" é algo bastante relativo no mundo capitalista atual. A distinção dicotômica "trabalho subordinado" x "trabalho autônomo" é insuficiente.

São raras as condições de trabalho efetivamente autônomas onde o capital e o trabalho convergem em um mesmo feixe. Tal se dá, exemplificativamente, como profissionais liberais que trabalhem realmente por conta próprio, como o advogado que mantém um próprio escritório e o médico que atue em um consultório de sua propriedade. Não são totalmente autônomas, no entanto, diversas formas de trabalho assim definidas no ordenamento jurídico pátrio, como, nos mesmos exemplos acima, do advogado que seja associado de um escritório e do médico que preste serviços a uma clínica. Embora tais relações de trabalho não se confundam com a relação de emprego por lhe faltarem elementos essenciais, é certo que essas atividades implicam em certa dependência do detentor do capital. Esse fenômeno já foi reconhecido pelo direito positivo de diversos países, como a Itália, com o trabalho parassubordinado em colaboração coordenada e continuativa; Portugal com o trabalho autônomo dependente; Espanha e França com o trabalho autônomo economicamente dependente, apenas para exemplificar.

Nelson Mannrich, na supracitada obra, define esse terceiro gênero de prestador de serviços da seguinte forma: "trabalhador parassubordinado é a pessoa natural que presta serviços autônomos e não eventuais, embora de forma coordenada, mediante remuneração e

\footnotetext{
${ }^{162}$ MANNRICH, Nelson. Autonomia, Parassubordinação e subordinação: os Diversos níveis de proteção do trabalhador e do Teletrabalhador. Disponível em http://www.mackenzie.br/fileadmin/Graduacao/ FDir/Artigos/nelson_manrich.pdf, pág. 1. (último acesso em 02/01/2013).
} 
uso de estrutura empresarial do tomador dos serviços, de quem depende economicamente, o que justifica tratamento assemelhado a de empregado."163

O trabalho autônomo dependente existe de fato no Brasil, embora sem o devido reconhecimento legislativo. Renata Orsi Bulgueroni aduz que "na prática das relações trabalhistas vêm sendo celebrados contratos que em muito se assemelham ao conceito de trabalho autônomo dependente elaborado pelos ordenamentos europeus. Portanto, embora legalmente não se possa falar em referida espécie de prestação de serviços, deve-se reconhecer sua existência nas relações de trabalho. ${ }^{164 \%}$

Do até aqui exposto no presente capítulo, pode-se verificar que a primeira característica comum do trabalho humano moderno é a sua inserção no modo capitalista de produção. O trabalho economicamente relevante, aquele que interessa ao Direito do Trabalho, é parte essencial do sistema capitalista. Poder-se-ia argumentar que há trabalho juridicamente dependente de proteção e que não está ligado diretamente à atividade produtiva em busca do lucro, como o trabalho doméstico e aquele prestado a instituições beneficentes. No entanto, mesmo essas formas de trabalho são ligadas ao contexto do capitalismo, ainda que não componham diretamente a relação conflituosa capital x trabalho. Com efeito, o trabalhador doméstico, por exemplo, ainda que não labore em contribuição direta para a produção de capital, o faz para receber o pagamento que lhe garantirá a subsistência no mundo capitalista em que vive, além de ser o seu trabalho que possibilitará os integrantes da família a quem trabalha que desenvolvam suas atividades, em geral econômicas, fora do âmbito do lar.

O segundo aspecto comum a todas as formas de trabalho é a sua condição de valor humano fundamental. Como já mencionado em outras passagens da tese e do próprio capítulo, a Constituição Federal consagra o trabalho como valor fundamental. Historicamente, o trabalho ganha o papel de dignificação do homem, independentemente de se adotar uma visão marxista, liberal, ou mesmo a ótica da doutrina social da igreja. O trabalho está intimamente ligado à própria condição existencial do homem. Socialmente, viver uma existência digna quer dizer viver por meio do trabalho, em seu mais amplo sentido, sem qualquer conotação técnica ${ }^{163}$ MANNRICH, Nelson. op. cit., pág. 5.

${ }^{164}$ BULGUERONI, Renata Orsi. Trabalho Autônomo Dependente: Experiências Italiana e Espanhola e a Realidade Brasileira. Dissertação de Mestrado apresentada junto à Universidade de São Paulo, São Paulo, 2011, pág. 195. 
ou restritiva a uma ou outra forma de labor. Assim, o trabalho como valor essencial do ser humano é mais uma característica comum a todas as formas de prestação de serviços.

A terceira característica comum a todas as formas de trabalho juridicamente relevantes para os fins dessa tese está intimamente ligada à primeira característica levantada. Com efeito, pode-se dizer que toda forma de trabalho vincula-se ao sustento do indivíduo trabalhador. O termo "sustento" deve ser aqui entendido em sentido amplo, já que há pessoas que trabalham não para sua subsistência física em padrões mínimos, mas para assegurar condições de vida que entenda dignas, bem como certo grau de satisfação pessoal. Tal característica poderia ser estendida até mesmo aos que trabalham na condição de voluntário, que fogem ao objeto dessa tese por não demandarem proteção jurídica específica, já que esses procuram preencher suas necessidades interiores que, ainda que não fisiológicas, podem se enquadrar no conceito de sustento. 


\section{DO NÚCLEO ESSENCIAL DE DIREITOS DE TODOS OS TRABALHADORES}

Ao se tratar da necessária expansão do objeto do Direito do Trabalho para adequação aos tempos atuais, é de primordial importância a discussão a respeito de um núcleo essencial de direitos de todos os trabalhadores. Com efeito, a identificação de tal núcleo corresponde à coluna de sustentabilidade do novo Direito do Trabalho, em seus aspectos aplicáveis a toda pessoa humana que trabalha, independentemente da modalidade de contratação e da efetiva forma da prestação de serviços.

O já citado jurista italiano Massimo D`Antona alertava que uma vez que a regulamentação do contrato de emprego não é suficiente para disciplinar as relações de trabalho em sentido amplo, deve ser aplicado um código protetivo, não necessariamente o mesmo em todos os casos, mas sempre com respeito a um mínimo denominador comum. Lembra o professor que nos dias atuais o trabalho subordinado é o único a receber a atenção do Direito do Trabalho, com cada vez maior diversificação interna segundo pesos e medidas ao menos arbitrários, enquanto o trabalho autônomo é praticamente privado de qualquer proteção. ${ }^{165}$

Inicia-se a discussão, em relação à realidade pátria, a despeito dos relevantes conceitos sociais, filosóficos e jurídicos a respeito do trabalho digno, em análise do direito positivo Constitucional brasileiro, especificamente o disposto no artigo $7^{\circ}$ da Carta Magna do País. Tal se dá pela interessante redação do artigo em referência que determina em seu caput: "São direitos dos trabalhadores urbanos e rurais, além de outros que visem à melhoria de sua condição social:(...)" (grifei). Com efeito, impende ressaltar que o Texto Magno, ao menos no caput do citado artigo, não se referiu a empregados, mas sim a trabalhadores.

\footnotetext{
${ }^{165}$ No texto original: "l'orizzonte patrimoniale del contratto si revela insufficiente a esaurire la disciplina del rapporto di lavoro e si dovrebbe rendere sempre applicabile un códice protettivo (non necessariamente lo stesso in tutti i casi, ma in ogni caso um mínimo comune denominatore; mentre oggi solo il lavoro subordinato richiama um codice protettivo, peraltro internamente sempre più differenziato secondo pesi e misure alquanto arbitrarie, mentre il lavoro autonomo ne è praticamente privo, seppure con qualche compensazione). D`ANTONA, Massimo. op. cit., pág. 322.
} 
Partindo da premissa que a Constituição Federal é redigida de forma técnica e das regras de hermenêutica constitucional que determinam a interpretação que atinja a maior eficácia possível dos direitos fundamentais, é sustentável a tese de que os direitos previstos no artigo $7^{\circ}$ da Carta da República se aplicam a todos os trabalhadores indistintamente e não apenas aos empregados. Nesse sentido o entendimento de Gabriela Neves Delgado de que “quando o art. $7^{\circ}$, caput, da Constituição Federal de 1988, elenca direitos constitucionais trabalhistas ele o faz para todo e qualquer trabalhador e não apenas para os empregados urbanos e rurais"

A interpretação da forma acima explicitada é reconhecida também por Flávia Moreira Guimarães Pessoa, que admite, no entanto, que o entendimento acabou não prevalecendo entre os estudiosos do Direito do Trabalho, propondo a retomada da discussão. Segundo a autora: “é interessante assinalar que a Constituição não fala em empregados urbanos e rurais, referindose genericamente a 'trabalhadores`. É clara a distinção entre as figuras, uma vez que empregado é uma espécie do gênero mais amplo trabalhador. Tal redação poderia dar margem ao entendimento de que os Direitos estabelecidos no art. $7^{\circ}$ são aplicáveis a todos os trabalhadores, mas essa leitura do referido dispositivo constitucional acabou não prevalecendo." ${ }^{\prime 167}$ Da mesma forma escreve Leandro Krebs Gonçalves para quem "ocorre que o art. $7^{\circ}$ da Constituição Federal define rol de direitos mínimos dos trabalhadores urbanos e rurais, sem qualquer distinção" e que "nesse encadeamento, permite-se afirmar que sua abrangência atingiria não só os empregados subordinados, ainda que isso possa parecer redundância, como também os autônomos." "168

Luiz Otávio Linhares Renault e Marcella Pagani, invocando a teoria dos Direitos Sociais como Direitos Fundamentais destacada em capítulo anterior desta tese afirmam que: "a melhoria das condições de vida do trabalhador está intimamente ligada com o exercício de um trabalho digno, que não pode se restringir somente ao modo, meio e condições de prestação do labor, mas, principalmente, à garantia e efetividade dos Direitos Sociais constitucionalmente

\footnotetext{
${ }^{166}$ DELGADO, Gabriela Neves. Direito Fundamental ao Trabalho Digno. São Paulo: LTR, 2006, pág. 215.

${ }^{167}$ PESSOA, Flávia Moreira Guimarães. "A Tutela das Relações de Trabalho em Sentido Amplo Por Meio de Hermenêutica Constitucional Concretizadora dos Direitos Trabalhistas Fundamentais Individuais". in Direitos Socigis na Cqustituição de 1988 - Uma análise crítica vinte anos depois. São Paulo: LTR, 2008, pág. 134.
} 
protegidos, que foram elevados ao patamar de Direitos Fundamentais pela nova ordem constitucional." 169

Reconhece-se que a interpretação até então adotada de forma majoritária é a restritiva, fundada na diferenciação típica do Direito do Trabalho, com a argumentação de que os direitos previstos na norma constitucional devem ser interpretados de acordo com o conjunto próprio do ramo juslaboral que é voltado ao empregado. Nesse sentido recorda Rodrigo Lacerda Carelli que: "por uma interpretação técnica gramatical, certamente a mais frágil, entender-se-ia que seriam sujeitos das normas qualquer tipo de trabalhador. Porém, como se tratam de normas de Direito do Trabalho elevadas ao grau constitucional, entendeu-se que essas normas seriam dirigidas aos trabalhadores subordinados." "170

Alexandre de Moraes sustenta que "por ausência de um conceito constitucional de trabalhador, para determinação dos beneficiários dos direitos sociais constitucionais devemos nos socorrer ao conceito infraconstitucional do termo, considerando para efeitos constitucionais o trabalhador subordinado, ou seja, aquele que trabalha ou presta serviços por conta e sob direção da autoridade de outrem, pessoa física ou jurídica, entidade privada ou

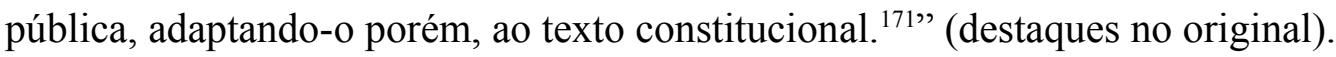

Restritiva também, embora em menor grau, a interpretação de Amauri Mascaro Nascimento para quem "a Constituição é aplicável ao empregado e aos demais trabalhadores nela expressamente indicados, e nos termos que o fez; ao rural, ao avulso, ao doméstico e ao servidor público. Não mencionando outros trabalhadores, como o eventual, o autônomo e o temporário, os direitos destes ficam dependentes de alterações da lei ordinária, à qual se restringem. ${ }^{172}$,

Não se concorda, no entanto, com tais interpretações, visto que, sob a ótica desta tese, realizada de modo invertido. Justamente por se tratar de Direito do Trabalho elevado ao nível constitucional é que os termos utilizados pelo Constituinte devem ser interpretados do modo

\footnotetext{
${ }^{169}$ PAGANI, Marcella; e RENAULT, Luiz Otávio Linhares. "Para uma Proteção Além do Trabalho". in Revista LTR. ano 76, v. 02, 2012, pág. 170.

${ }^{170}$ CARELLI, Rodrigo Lacerda. Formas Atípicas de Trabalho. São Paulo: LTR, 2004, pág. 152. (versão digital).

${ }^{171}$ MORAES, Alexandre de. op. cit., pág. 202.

${ }^{172}$ NASCIMENTO, Amauri Mascaro. Direito do Trabalho na Constituição de 1988. São Paulo: Saraiva, 1989, pág. 34.
} 
mais amplo possível. Se a vontade do Constituinte houvesse sido restringir a aplicação dos direitos que elenca aos trabalhadores subordinados, bastaria ter se utilizado da palavra "empregado". Se não o fez, algo extremamente simples, ressalte-se, é porque pretendia a aplicação ampliativa.

Com efeito, o conceito de empregado como trabalhador subordinado é clássico e préexistente ao vigente texto constitucional. Não se vislumbra qualquer necessidade de conceituação constitucional de trabalhador ou socorro ao ordenamento infraconstitucional. Bastaria utilizar a expressão "empregado" para a apenas eles dirigir as normas do Direito do Trabalho, sem necessidade de uma misteriosa escolha pela expressão "trabalhador" que poderia suscitar leitura ambígua. Quer parecer ao autor dessa tese, assim, que o Constituinte utilizou-se propositalmente do termos "trabalhadores" para dirigir seus comandos a um maior grupo de pessoas, ainda que a efetivação de tais comandos dependa de algumas reformas de normas de caráter infraconstitucional.

A leitura abrangente do disposto no artigo $7^{\circ}$ da Constituição Federal deve passar pelos critérios de hermenêutica constitucional já debatidos no capítulo ( ) da tese, em especial no que diz respeito ao sopesamento de princípios e na vedação de se interpretar a norma constitucional de modo a lhe suprimir o sentido de algum dos termos utilizados.

De grande relevância, no estudo em questão, a análise do texto do artigo $7^{\circ}$ do Texto Magno à luz do princípio da dignidade da pessoa humana. Sobre tal tema ensina a Ministra Maria Cristina Irigoyen Peduzzi que "a crescente aplicação do princípio, quer para colmatar lacunas jurídicas, quer para dar efetividade a direitos assegurados pela lei ou pela Constituição, revela a importância de compreender a sua normatividade, buscando coerência na interpretação do direito. Nessa perspectiva, é relevante que o princípio da dignidade da pessoa humana seja concebido a partir de um estudo adequado do significado que ele atingiu com o Estado Democrático de Direito." 173

\footnotetext{
${ }^{173}$ PEDUZZI, Maria Cristina Irigoyen. "O Princípio da Dignidade da Pessoa Humana e Sua Eficácia Concreta". in MANNRICH, Nelson et. al. (coords.). Reconstrução do Direito do Trabalho - Anais da Academia Nacional de Direito do Trabalho 2010. São Paulo: LTR, 2010, pág. 185.
} 
Uma Constituição que está fundamentada na busca pela dignidade da pessoa humana e valorização do trabalho e que se utiliza da expressão "trabalhadores" na definição dos direitos que elenca com relação ao trabalho não deve ser interpretada de modo restritivo.

Com efeito, a interpretação que melhor se coaduna com a busca de uma maior dignidade humana e que melhor valoriza o trabalho é aquela que reconhece a todos os trabalhadores, termo do qual se utilizou o Constituinte, os direitos previstos no artigo $7^{\circ}$ da Carta Constitucional.

O Direito do Trabalho amplo que se defende no presente texto deve ter início, portanto, na aplicação ampliativa dos direitos previstos no artigo $7^{\circ}$ da Constituição Federal. Debater-seá cada um dos direitos ali previstos separadamente, indicando a compatibilidade com formas de trabalho que não a relação de emprego clássica, já que algumas das normas não encontram campo de aplicação em outras esferas de trabalho, ainda que se trate de interpretação ampla.

Assim, o artigo $7^{\circ}$ da Carta da República elenca aos trabalhadores os direitos constantes de seus 34 incisos, além de outros que visem a melhoria da sua condição social.

O inciso I do citado artigo possui a seguinte redação: "relação de emprego protegida contra despedida arbitrária ou sem justa causa, nos termos de lei complementar, que preverá indenização compensatória, dentre outros direitos." Por se tratar de norma destinada a especificidade da relação empregatícia, não se vislumbra sua aplicação ampliativa a outras formas de trabalho. As medidas flexíveis reconhecidas e o trabalho autônomo, ainda que dependente, são destinados, em grande parte, a suprir necessidades de serviço temporário e determinado, não se justificando proteção específica em face de despedida arbitrária, exceto para os casos de rompimento contratual antecipado, o que prescinde de norma constitucional.

Dispõe o inciso II do artigo em comento "seguro-desemprego, em caso de desemprego involuntário". Embora necessite da adaptações na legislação infraconstitucional, esse dispositivo é plenamente aplicável a outras formas de relação de trabalho que não a de emprego. A política de seguro-desemprego, ou de remuneração mínima assegurada para períodos de não-trabalho, é uma das principais figuras do elemento "segurança" que deve ser oferecido pelo Estado em um ambiente de flexicurity. A norma constitucional garante o direito, devendo a regulamentação ser feita pela legislação ordinária, podendo estabelecer requisitos como tempo mínimo de serviços prestados, recolhimentos previdenciários 
específicos, participação em cursos de qualificação e programas de recolocação profissional, dentre outros. A norma é, portanto, compatível com a expansão do Direito do Trabalho, devendo compor o núcleo de direitos de todos os trabalhadores.

Trata o inciso III do "fundo de garantia do tempo de serviço." Sem se adentrar na historicidade do instituto, é possível se vislumbrar sua aplicação a outras formas de trabalho além da relação de emprego. É possível a reforma da legislação ordinária para se determinar, por exemplo, que do valor pago por um contrato de prestação de serviços por pessoa física, ainda que autônoma, se destine determinada importância a título de fundo de garantia, constituindo uma espécie de poupança obrigatória para suprir custos de períodos de "nãotrabalho". Conclui-se pela compatibilidade do instituto com os termos propostos na tese.

$\mathrm{O}$ inciso IV se refere ao "salário mínimo, fixado em lei, nacionalmente unificado, capaz de atender a suas necessidades vitais básicas e às de sua família com moradia, alimentação, educação, saúde, lazer, vestuário, higiene, transporte e previdência social, com reajustes periódicos que lhe preservem o poder aquisitivo, sendo vedada sua vinculação para qualquer fim.” Uma vez mais, embora necessite da adaptações na legislação ordinária, o dispositivo em comento pode ter sua aplicação ampliada, ao menos em linhas gerais. É cabível a determinação do pagamento, por exemplo, de um valor horário mínimo para toda e qualquer forma de prestação de serviço. Tal medida, além de promover a dignidade do ser humano como trabalhador, contribui para evitar a prática de um "auto dumping social" que reduziria o valor do trabalho de acordo com as leis econômicas da oferta e da procura. Tratar-se-ia de uma interferência estatal na autonomia contratual privada, inclusive dos trabalhadores autônomos, com finalidade social de proteger o trabalho e a dignidade humana. O salário-mínimo deve compor o núcleo mínimo de direitos de todos os trabalhadores.

Refere-se o inciso V ao "piso salarial proporcional à extensão e à complexidade do trabalho". Tal norma é de aplicabilidade mais duvidosa a uma gama ampla de relações de trabalho. Por ser norma aberta e ampla, sua regulamentação infraconstitucional da todas as formas de trabalho encontra dificuldades insuperáveis. Deixa-se de incluir tal dispositivo no núcleo essencial de direitos dos trabalhadores em sentido amplo.

Os incisos VI, que versa sobre "irredutibilidade do salário, salvo o disposto em convenção ou acordo coletivo"; e VII, da "garantia de salário, nunca inferior ao mínimo, para 
os que percebem remuneração variável" podem ser aplicados com os mesmos fundamentos relativos ao salário-mínimo, previsto no inciso IV. Deve ser ressaltada a necessidade de adaptações, no entanto. Com efeito, a irredutibilidade salarial deve ser entendida dentro do prazo do mesmo contrato, seja ele de trabalho atípico ou autônomo. A garantia do saláriomínimo para a remuneração variável deve ter em vista o salário-mínimo horário e a quantidade de horas contratadas. Em sendo a contratação por obra certa, deve o contrato, a legislação ordinária, ou as normas coletivas fixarem a distribuição da remuneração mínima pelo módulo de tempo previsto para a conclusão do serviço.

O direito previsto no inciso VIII, “décimo terceiro salário com base na remuneração integral ou no valor da aposentadoria" é passível de aplicação na forma disposta em lei ordinária, podendo se tratar, por exemplo, do acréscimo de 1/12 sobre os valores a serem pagos pelos serviços contratados.

Também encontra guarida no núcleo fundamental de direitos de todos os trabalhadores o disposto no inciso IX do artigo $7^{\mathrm{a}}$ da Constituição que trata da "remuneração do trabalho noturno superior à do diurno." Embora necessária a ressalva de que a legislação ordinária pode ter dificuldades em regular o pagamento em questão quando da ausência de controle de horário, certo é que determinados serviços são contratados especificamente para execução em período noturno, como ocorre com obras de manutenção de empreendimentos com alta circulação de pessoas durante o dia. Inegável, ainda, que o caráter de penosidade do trabalho noturno é o mesmo para um trabalhador autônomo, atípico ou empregado em sentido clássico.

Deixa-se de incluir no núcleo em comento o inciso $\mathrm{X}$, da "proteção do salário na forma da lei, constituindo crime sua retenção dolosa". Com efeito, o inciso envolve Direito Penal, fundado em tipificação e o termo "salário" é específico da relação de emprego. Tendo em vista que não cabe interpretação ampliativa em Direito Penal, a norma não pode ser aplicada a outras formas de remuneração.

Não deve compor o núcleo essencial de direitos de todos os trabalhadores o disposto no inciso XI que trata da "participação nos lucros, ou resultados, desvinculada da remuneração, e, excepcionalmente, participação na gestão da empresa, conforme definido em lei." Com efeito, não há necessidade de previsão de uma parcela específica desvinculada da remuneração para um trabalhador que presta seus serviços de forma distinta da relação empregatícia. Ademais, 
em regra um trabalhador autônomo e um que presta serviços por meio de contratos atípicos não se vincula por longos períodos a um só tomador de serviços, não justificando a participação em lucros ou resultados, muito menos a participação na gestão de uma empresa com a qual não firma fortes laços.

Por se tratar de benefício previdenciário, ainda que o pagamento possa se dar diretamente pelo empregador, o inciso XII que trata do "salário-família pago em razão do dependente do trabalhador de baixa renda nos termos da lei”, pode ser regulamentado para pagamento a todos os trabalhadores, independentemente da existência de uma relação de emprego.

Questão delicada é a prevista no inciso XIII referente à "duração do trabalho normal não superior a oito horas diárias e quarenta e quatro semanais, facultada a compensação de horários e a redução da jornada, mediante acordo ou convenção coletiva de trabalho". Desde a origem do Direito do Trabalho, a limitação da jornada sempre foi uma das principais bandeiras das necessidades do trabalhador. Sem a proteção jurídica, a tendência era a prática de jornadas cada vez maiores para se atingir, supostamente, uma maior produção com menor custo. Tal qual acontece com o salário, a jornada de trabalho não pode ser relegada às leis da oferta e da procura, sob pena de se reduzir o trabalhador à condição de mercadoria. Não há dúvida, assim, que a limitação da duração do trabalho deva compor o núcleo essencial de direitos de todos os trabalhadores. No entanto, a forma como deve ser implementada essa limitação não é isenta de dificuldades. Com efeito, uma das características do trabalho autônomo é justamente a ausência de controle de horário. É simples a determinação legal que proíba a contratação de serviços que excedam oito horas diárias pelo mesmo trabalhador, mas é delicada a forma de fiscalização que deverá ser definida por meio da legislação ordinária ou norma coletiva, do mesmo modo que as questões envolvendo compensação de horário e redução de jornada.

Também no tocante à duração do trabalho, determina o inciso XIV a "jornada de seis horas para o trabalho realizado em turnos ininterruptos de revezamento, salvo negociação coletiva." O trabalho em turnos ininterruptos de revezamento pressupõe, por si só, profunda inserção do trabalhador na estrutura empresarial. Cerebrina a hipótese de trabalho autônomo em turnos ininterruptos de revezamento, podendo, no entanto, serem utilizadas formas contratuais atípicas e, comumente, trabalho terceirizado, também objeto do núcleo tratado 
nesse capítulo. Do mesmo modo que a limitação de jornada geral, o dispositivo é aplicável, com as ressalvas relativas à fiscalização a ser regulamentada.

Os períodos de descanso como o definido no inciso XV que se refere ao "repouso semanal remunerado, preferencialmente aos domingos" também se incluem na luta histórica do Direito do Trabalho para assegurar condições dignas de labor. O dispositivo deve ser aplicado, assim, a todas as formas de trabalho, com a ressalva de que sua efetivação somente é possível quando os serviços contratados sejam desenvolvidos em um módulo de ao menos uma semana.

Retomando o alerta quanto às particularidades da fiscalização de horário, por se tratar de elemento vinculado, ainda que de modo patrimonial, à limitação da jornada de trabalho, entende-se que o disposto no inciso XVI, "remuneração do serviço extraordinário superior, no mínimo, em cinqüenta por cento à do normal", deve compor o núcleo essencial de direitos de todos os trabalhadores. A contratação não deve se dar por módulos superiores a oito horas diárias e quarenta e quatro semanais, no entanto, ultrapassados tais limites, independentemente do motivo, as horas excedentes devem ser remuneradas com o adicional.

$\mathrm{O}$ "gozo de férias anuais remuneradas com, pelo menos, um terço a mais do que o salário normal", previsão do inciso XVII, também pode ser estendido a todos os trabalhadores. No entanto, para sua operacionalização, concorda-se com o entendimento de Flávia Moreira Guimarães Pessoa ao afirmar que "há que salientar, porém, especialmente em relação às férias, que esse direito somente se poderá efetivar em relação às prestações de serviços de natureza contínua no decorrer do ano, não havendo como se verificar nas relações de trabalho meramente eventuais. ${ }^{174}$,

A "licença à gestante, sem prejuízo do emprego e do salário, com a duração de cento e vinte dias" prevista no inciso XVIII e a "licença-paternidade, nos termos fixados em lei" prevista no inciso XIX, devem compor o núcleo de direitos essenciais em discussão. Por se tratarem de períodos de "não-trabalho" remunerados, ambos devem ser regulamentados e garantidos sob a forma de benefícios previdenciários estatais, obtendo seu custeio de contribuições específicas vinculadas à remuneração dos serviços nos períodos de prestação de

\footnotetext{
${ }^{174}$ PESSOA, Flávia Moreira Guimarães. op. cit. (2), pág. 145.
} 
serviços, podendo a legislação ordinária estabelecer requisitos como, exemplificativamente, períodos de carência e número mínimo de contribuições em determinado espaço de tempo.

Sem adentrar a discussão a respeito das ações afirmativas, é certo que o disposto no inciso XX sobre a "proteção do mercado de trabalho da mulher, mediante incentivos específicos, nos termos da lei" é perfeitamente aplicável a todos os trabalhadores, ou no caso a todas as trabalhadoras, por meio de medidas estatais específicas.

$\mathrm{O}$ “aviso prévio proporcional ao tempo de serviço, sendo no mínimo de trinta dias, nos termos da lei” previsto no inciso XXI não é componente do núcleo essencial de direitos aqui debatido. O instituto do aviso prévio está intimamente conectado ao contrato por prazo indeterminado, realidade diversa da maioria dos contratos flexíveis e do trabalho autônomo, em geral por prazo determinado ou obra certa.

Outra preocupação originária do Direito do Trabalho é a saúde e a segurança do trabalhador. Assim, não há dúvida de que a "redução dos riscos inerentes ao trabalho, por meio de normas de saúde, higiene e segurança" prevista no inciso XXII deve ser considerada parte integrante do núcleo essencial de direitos de todos os trabalhadores, não constituindo particularidade da relação de emprego.

$\mathrm{O}$ "adicional de remuneração para as atividades penosas, insalubres ou perigosas, na forma da lei" previsto no inciso XXIII pode ser aplicado a todas as formas de trabalho. Evidentemente que se faz necessária regulamentação infraconstitucional específica para outras formas de trabalho que não a de emprego, devendo ser ressaltada a dificuldade de caracterização do ambiente insalubre, perigoso ou penoso inerente aos contratos de curta duração. Tal dificuldade, no entanto, não impede a conceituação do adicional, já que, como afirmado em relação a outros incisos do artigo em comento, o fato de o trabalho ser prestado de forma autônoma, por exemplo, não o torna menos perigoso, penoso ou insalubre do que quando feito sob subordinação clássica.

O direito à "aposentadoria" constante do inciso XXIV já é reconhecido atualmente pela legislação previdenciária infraconstitucional para outras categorias de trabalhadores que não os empregados, sendo, assim, indiscutível sua aplicabilidade para os fins do presente capítulo.

Também se refere a medida estatal consubstanciada em políticas de welfare a “assistência gratuita aos filhos e dependentes desde o nascimento até 5 (cinco) anos de idade 
em creches e pré-escolas" constante do inciso XXV do artigo $7^{\circ}$ da Constituição Federal. Nada obsta sua extensão a todos os trabalhadores, podendo a legislação infraconstitucional regulamentar a matéria, em especial no que se refere às fontes de custeio.

Tema delicado, mas de crucial importância é o "reconhecimento das convenções e acordos coletivos de trabalho" constante do inciso XXVI. Não há dúvida de que deve ser assegurado o reconhecimento das normas coletivas produzidas por sindicatos que representem todas as formas de trabalho. A discussão a respeito da necessária reforma do modelo sindical pátrio de unicidade foge ao escopo desse trabalho, já que demandaria uma tese própria e de extensão em muito superior à presente, não podendo, no entanto, deixar de ser mencionada nesse tópico. Assim, apenas registre-se que o desenvolvimento pleno da negociação coletiva em âmbito mais amplo que o da relação de emprego, hoje pífio no direito pátrio, demandaria um sistema de efetiva liberdade sindical, sem a atual unicidade, divisão em categorias e custeio compulsório.

É bastante genérico o disposto no inciso XXVII do artigo $7^{\circ}$ da Norma Ápice. Prevê o citado dispositivo a "proteção em face da automação, na forma da lei." Trata-se de uma diretiva que não mereceu maiores considerações do legislador ordinário nos quase vinte e cinco anos transcorridos desde a promulgação da Carta da República. O escopo da norma é a garantia do nível de ocupação, não se tratando, a rigor, de um direito do trabalhador, pelo que se deixa de incluir tal inciso no núcleo essencial em comento.

Deve ser conferido a todos os trabalhadores também o "seguro contra acidentes de trabalho, a cargo do empregador, sem excluir a indenização a que este está obrigado, quando incorrer em dolo ou culpa" previsto no inciso XXVIII. Uma vez mais, necessária a correção terminológica, já que a norma se utiliza da expressão “empregador”. Não há, no entanto, qualquer incompatibilidade de referido dispositivo constitucional com outras formas de trabalho, não sendo o seguro contra acidentes, tampouco a responsabilidade civil elementos exclusivos de uma relação de emprego.

Deixa-se de incluir no rol essencial o inciso XXIX que prevê a "ação, quanto aos créditos resultantes das relações de trabalho, com prazo prescricional de cinco anos para os trabalhadores urbanos e rurais, até o limite de dois anos após a extinção do contrato de trabalho." O direito de ação é assegurado a todos, independentemente da condição de 
trabalhador. Desse modo, a previsão em tela seria inócua, não fosse por sua segunda parte que não é efetivamente um direito do trabalhador, mas uma limitação a esse, já que fixa um prazo prescricional. Não se trata, assim, de elemento a ser incluído no núcleo essencial de direitos de todos os trabalhadores.

Não há dúvida de que devem compor o núcleo essencial de direitos de todos os trabalhadores o disposto nos incisos XXX, da "proibição de diferença de salários, de exercício de funções e de critério de admissão por motivo de sexo, idade, cor ou estado civil"; XXXI, sobre a "proibição de qualquer discriminação no tocante a salário e critérios de admissão do trabalhador portador de deficiência"; e XXXII, referente à "proibição de distinção entre trabalho manual, técnico e intelectual ou entre os profissionais respectivos." Necessária somente a adaptação do termo "salário", que é inerente à relação de emprego, devendo ser tal termo lido como remuneração ou contraprestação pelos serviços desenvolvidos pelo trabalhador. Seria uma contradição não aplicar a proibição de formas de discriminação no trabalho a outras categorias que não os empregados, já que tal fato, por si só, caracterizaria injustificável discriminação.

Trata o inciso XXXIII da "proibição de trabalho noturno, perigoso ou insalubre a menores de dezoito e de qualquer trabalho a menores de dezesseis anos, salvo na condição de aprendiz, a partir de quatorze anos." O dispositivo deve ser incluído no rol de direitos de que trata o presente capítulo. Ressalte-se que o próprio trabalho na condição de aprendiz a que se refere o inciso é previsto pela legislação infraconstitucional em um contrato especial, distinto da relação de emprego clássica.

Não constitui parte do núcleo essencial de direitos dos trabalhadores o inciso XXXIV, sobre a "igualdade de direitos entre o trabalhador com vínculo empregatício permanente e o trabalhador avulso". Evidente que é louvável o dispositivo, já que estende direitos aos trabalhadores avulsos. No entanto, a não inclusão no núcleo em comento se dá por ser a norma bastante específica, identificando de modo taxativo seus destinatários, os trabalhadores avulsos, não havendo espaço para interpretação extensiva. Pelo mesmo motivo, não se pode incluir no rol essencial o disposto no parágrafo único do artigo $7^{\circ}$ que trata dos direitos aplicáveis aos trabalhadores domésticos. 
Pode-se concluir que o núcleo essencial de direitos de todos os trabalhadores deve ser composto por, no mínimo, os incisos II, III, IV, VI, VII, VIII, IX, XII, XIII, XIV, XV, XVI, XVII, XVIII, XIX, XX, XXII, XXIII, XXIV, XXV, XXVI, XXVIII, XXX, XXXI, XXXII e XXXIII do artigo $7^{\circ}$ da Constituição Federal, evidentemente que com as necessárias adaptações e regulamentação infraconstitucional.

A conjunção da interpretação ampliativa do artigo $7^{\circ}$ da Constituição Federal, medidas de flexibilização que impliquem em maior reconhecimento de formas atípicas de trabalho e de trabalho autônomo inserido na unidade produtiva alheia, além de políticas de incentivo à empregabilidade e proteção do trabalhador em sentido amplo, é o melhor modo de se promover a valorização do trabalho e da dignidade humana ao mesmo tempo em que se enfrenta a crise econômica e jurídica do Direito do Trabalho. Esse conjunto de medidas pode ser atingido por meio da flexicurity, como se verá a seguir. 


\section{Desafios da Flexicurity e o Modelo Brasileiro de Relações de Trabalho}

Considerando-se tudo o que foi tratado ao longo do presente texto, a proposta que se tem a fazer com relação às peculiaridades do Direito do Trabalho brasileiro em face da crise anteriormente identificada consiste na mudança de paradigma do protecionismo do empregado à proteção do trabalhador por meio da flexicurity, ou flexisegurança.

Trata-se de contribuição

O escopo da tese em desenvolvimento pode ser definido em duas partes. A primeira consiste em demonstrar a necessidade de adaptação do Direito do Trabalho à realidade sócioeconômico-jurídica atual, com a crescente demanda por formas de trabalho distintas da relação de emprego clássica, o que implica em inevitáveis medidas de flexibilização. A segunda parte, tomando por premissa a necessidade de flexibilização acima, diz respeito à necessária ampliação do objeto do Direito do Trabalho para atender a toda forma de prestação de serviços em condições de hipossuficiência jurídica, independentemente da existência de contrato de trabalho no sentido típico, ou mesmo de relação de emprego.

Com efeito, como verificado no estudo concernente ao Direito do Trabalho na União Europeia, a proliferação de formas atípicas de trabalho permite as adaptações empresariais necessárias para a resposta à crise econômica, além de conferir maior flexibilidade para distribuição de horários aos trabalhadores. No entanto, a flexibilização por meio do reconhecimento das formas atípicas de labor por si só implica risco de precarização de condições de vida, oferecendo ao trabalhador uma sucessão de contratos de má-qualidade e curta-duração. A consecução dos benefícios da flexibilidade, sem que se recaia nos efeitos perversos citados, somente pode ser atingida com a existência de uma estrutura de suporte ao trabalhador, com programas de qualificação e recolocação profissional e seguro-desemprego que configuram, em conjunto, a já estudada flexicurity.

A reforma do Direito do Trabalho, assim, deve focar em novas modalidades de proteção. Como lembrado por Luis Otávio Linhares Renault e Marcella Pagani: “a proteção almejada é aquela que visa garantir a vida digna do trabalhador face à perversidade do 
mercado econômico, garantindo-lhe trabalho e educação decentes, capazes de lhe proporcionar autonomia frente às conjunturas mercadológicas."175

Os interesses a serem tutelados não podem ser somente os econômicos, pelo contrário, o foco deve ser sempre o ser humano trabalhador, não há qualquer sentido no progresso econômico com o aviltamento do beneficiário das riquezas geradas, a pessoa humana. Lúcida a lição a esse respeito de José Aparecido dos Santos de que "trata-se de superar o condicionamento econômico, de ultrapassar a ideologia pueril e desmentida de que o desenvolvimento econômico geral do País, por si só, é suficiente para eliminar a desigualdade social. Há que se admitir que, por mais que esse País tenha se desenvolvido, subsiste uma 'ralé estrutural de pessoas a quem atribuímos a marca indelével de 'subgente' e a quem o ordenamento jurídico parece ignorar. Cabe superar essa nódoa para que a pessoa concreta e histórica do trabalhador passe a importar, inclusive quando se almeja verificar se há autonomia ou subordinação. ${ }^{176 "}$

A forma de combinar as duas partes do objetivo da tese descritas acima é a utilização de um modelo específico de flexicurity ou flexisegurança para o direito brasileiro. A flexisegurança, como também já debatido, consiste em fomentar a flexibilidade no mercado de trabalho conjugada com a segurança para o trabalhador, sendo aqui defendido que essa segurança deve consistir na aplicação de um núcleo mínimo de direitos a todos os trabalhadores, ainda que não contratados na forma de empregados típicos.

A reforma, portanto, não pretende excluir ou reduzir o objeto do Direito do Trabalho. Como ensina Mauricio Godinho Delgado ao tratar das consequências da crise econômica e jurídica que envolve o ramo juslaboral: "na verdade, parece clara ainda a necessidade histórica de um segmento jurídico com as características essenciais do Direito do Trabalho. Parece inquestionável, em suma, que a existência de um sistema desigual de criação, circulação e apropriação de bens e riquezas, com um meio social fundado na diferenciação econômica entre seus componentes (como o capitalismo), mas que convive com a liberdade forma dos indivíduos e com o reconhecimento jurídico-cultural de um patamar mínimo para a ${ }^{175}$ PAGANI, Marcella; e RENAULT, Luiz Otávio Linhares. op. cit., pág. 174.

176 SANTOS, José Aparecido dos. Fundamentos da Subordinação Jurídica do Trabalhador: Sujeição e Construção da Cidadania. Dissertação de Mestrado apresentada junto à Pontifícia Universidade Católica do Paraná, Curitiba, 2009, págs. 199/200. 
convivência na realidade social (aspectos acentuados com a democracia), não pode desprezar ramo jurídico tão incrustado no âmago das relações sociais, como o justrabalhista. ${ }^{177,}$

Adalberto Perulli, ao tratar da flexicurity afirma que a nova orientação do Direito do Trabalho é voltada a mercados de trabalho onde o equilíbrio é mantido por meio de uma forma de justiça social, que não é mais orientada ou baseada na segurança do emprego, mas na aquisição de habilidades específicas para serem utilizados nos caminhos de "transição laboral”. Essas mudanças incluem a transição entre empregos, entre emprego e desemprego, entre formação inicial e trabalho contínuo remunerado, entre atividades domésticas ou comunitárias e emprego, e entre inatividade (ou inatividade por incapacidade) e emprego ${ }^{178}$.

Ao se discutir a aplicação da flexicurity no Brasil, deve-se frisar que sua definição aponta para a busca da importação do espírito e da finalidade do conceito e não de práticas ou modelos específicos. Nesse sentido, afirma o supracitado professor Adalberto Perulli que "a flexicurity se torna uma receita geral para a modernização do Direito do Trabalho e que se aplica não apenas para a 'inclusão social do mais fraco' objetivamente, mas também deve também ser vista como uma reforma do mercado de trabalho. Por essa razão, não é apenas uma reforma para imitação das melhores práticas (i.g. os casos holandês e dinamarquês), mas também como inspiração para reformas domésticas. ${ }^{179 "}$

Como ressaltado no capítulo anterior, o modelo brasileiro de flexicurity não pode ser concebido como uma simples transposição do conceito dinamarquês. A maioria dos estudos a

${ }^{177}$ DELGADO, Maurício Godinho. Curso de Direito do Trabalho. São Paulo: LTr, 2002, pág. 94.

${ }^{178}$ No texto original: "labour law gives the way to labour markets in which an equilibrium is maintained through a promise of social justice which is no longer oriented on (or based upon) the security of employment, instead on the "acquisition of specific capabilities to be spent along the unknown paths of labour's "transitions". These include transitions between jobs, transitions between unemployment and employment, transition between initial education and continuing paid employment, transition from household activities or community service to employment, transition from inactivity (or inactivity due to disability) to employment." PERULLI, Adalberto. Social rights and administrative regulations for effectiveness and sustainability: What modernization of labour law?. Genebra: OIT, 2012, pág. 18.

${ }^{179}$ No original: "flexicurity becomes a general recipe for a modernization of labour law that applies not only to the 'social inclusion of the weakest' objective, but must also be seen as a reform of the labour market. For this reason, it is not only reform for the imitation of best practice (i.e. the Dutch and Danish cases), but also as inspiration for domestic reforms." PERULLI, Adalberto. op. cit., pág. 20. 
respeito da flexicuity no Brasil foram desenvolvidos no campo econômico e não no jurídico, chegando-se à conclusão da inviabilidade da adoção de medidas nos moldes da Dinamarca por conta das disparidades inconciliáveis entre as realidades brasileira e dinamarquesa. Nesse diapasão, José Paulo Zeetano Chahad aponta, por exemplo, as seguintes diferenças entre os países, dentre outras: população brasileira de 188, 7 milhões em 2006 x população dinamarquesa de 5,7 milhões em 2006 conforme dados do Banco Mundial; renda per capita nacional de 4.730 dólares americanos em 2006 x renda per capita na Dinamarca de 51.700 dólares americanos confome dados do Banco Mundial; índice de desenvolvimento humano brasileiro de 0,80 em 2007 e dinamarquês de 0,95 no mesmo ano conforme dados da Organização das Nações Unidas; e índice da alfabetização em pessoas com mais de 15 anos no Brasil de $88 \%$ contra 99\% na Dinamarca, ambos em 2005, conforme levantamento do IBGE. ${ }^{180}$

No entanto, em que pese a existência das substanciais diferenças nos indicadores sócioeconômicos, volta-se a afirmar que é possível a adoção de reformas no âmbito do direito positivo capazes de possibilitar a criação de um modelo factível de flexicurity para a realidade brasileira.

O primeiro ponto do vocábulo definidor da teoria em estudo, relativo à flexibilidade, já existe em grande medida no país, como tratado no tópico geral sobre a flexicurity. Com efeito, deve ser lembrado em primeiro lugar que o Direito do Trabalho brasileiro já é extremamente flexível se comparado ao Direito do Trabalho europeu que deu início ao movimento da flexisegurança. Concordam com tal assertiva até mesmo defensores da flexibilização ampla, inclusive de normas trabalhistas constitucionais, como Dagoberto Lima Godoy para quem: "a legislação trabalhista brasileira é mais liberal que a europeia ou as de outras regiões, em termos de flexibilidade interna e externa, (...), com destaque para a liberdade de contratação e de dispensa; ou seja, é relativamente pouco o que resta a flexibilizar". ${ }^{181}$

\footnotetext{
${ }^{180}$ CHAHAD; José Paulo Zeetano. Flexible Labour Markets, Workers Protection and Lifelong Learning of the Labour Force in a Global Economy: Latin American and Caribbean Experiences and Perspectives - A Experiência Brasileira. São Paulo, 2008. Disponível em http://www.cepal.org/ de/agenda/1/36021/Jos \%C3\%A9_Paulo_Zeetano_Chahad.pdf (último acesso em 12/01/2013).

${ }^{181}$ GODOY, Dagoberto Lima. Flexisseguridade no Brasil. São Paulo: LTR, 2010, pág. 182.
} 
A solução da problemática, sob a perspectiva adotada nessa tese, não implica a desregulamentação do trabalho ou a redução de direitos, ou mesmo de encargos, para os empregados com contratos de trabalho típicos. Não se prega o fim dos empregos, que ainda possuem seu (relevante) espaço no mercado de trabalho, mas se afirma que há situações diversas nas quais o trabalho necessita ser tomado em formas variáveis de contratação, incluindo o trabalho sem vínculo de emprego.

A reforma que se defende para o direito brasileiro segue o sentido inverso do comumente adotado para o termo flexibilização. Com efeito, o mercado de trabalho brasileiro pode se tornar mais flexível com um aumento da regulamentação estatal, ao contrário da diminuição sustentada pelos defensores da flexibilização ampla.

$\mathrm{O}$ aumento da regulamentação estatal aqui defendido diz respeito à criação de um núcleo mínimo de direitos trabalhistas que deve incidir automaticamente em toda a contratação de serviço humano prestado por pessoa física, inclusive quando efetuada a contratação fora das bases da relação de emprego típica.

O Direito do Trabalho, incluído o Direito do Trabalho expandido que se sustenta no texto, não resiste, por razões inerentes à sua essência, ao dogma da livre pactuação individual que rege os contratos de caráter civil em geral. O trabalhador é hipossuficiente no âmbito contratual, inclusive na maioria dos casos envolvendo a prestação de serviços autônomos e os chamados parassubordinados. Caso não haja o intervencionismo estatal mínimo por meio do direito, é inevitável que a dignidade de tais trabalhadores acabará ferida por conta de contratos onde o conteúdo refletirá uma relação de domínio do tomador de serviços contratante em detrimento do conteúdo humano mínimo que deve reger as relações de trabalho.

No mesmo sentido, da necessidade de regulamentação das condições de trabalho, alerta Hélio Zylberstajn que “...o mercado de trabalho padece de problemas específicos, que afetam negativamente seu funcionamento. Como todos os mercados, há um lado da oferta (os trabalhadores) e um lado da demanda (as empresas). Os dois lados interagem em condições não exatamente equilibradas. O poder das empresas é - em geral - maior que o dos trabalhadores. A iniciativa nesse mercado é sempre das empresas, pois são elas que decidem quantos empregados querem contratar. Os trabalhadores reagem a partir do movimento das 
empresas. Para estabelecer condições de contratação mais equilibradas, as sociedades utilizam diversos processos e mecanismos de regulação"182.

Deve-se notar, uma vez mais, que a proposta apresentada não implica a eliminação do trabalho autônomo, cooperado, parassubordinado ou atípico. O núcleo mínimo de direitos defendido não é igual ao conteúdo completo do Direito do Trabalho que rege a relação empregatícia clássica, tampouco geraria os mesmos custos para a contratação. Trata-se, no entanto, do mínimo essencial para se assegurar a existência digna do ser humano que trabalha.

Com efeito, lembra Gabriela Neves Delgado, ao defender a aplicabilidade do disposto no artigo $7^{\circ}$ da Constituição Federal a todos os trabalhadores e não somente aos empregados que "é claro que a concessão dos direitos constitucionais trabalhistas será assegurada a cada trabalhador conforme a possibilidade da própria estrutura de trabalho estabelecida, o que não significa a defesa de discriminações, mas pelo contrário, o respeito às diferenças estruturais que se estabelecem no mundo do trabalho." 183

A vantagem do ponto de vista empresarial é de que a contratação de trabalhadores em modos diversos da tipificação clássica de contrato de emprego será prevista especificamente na legislação, definindo de modo prévio as hipóteses de cabimento e os custos envolvidos. $\mathrm{O}$ tomador de serviços (não se utiliza o termo empregador por motivo estritamente técnico, vez que esse somente pode tomar o trabalho de empregados em sentido estrito) poderá contar com formas flexíveis de prestação de serviços de forma legal e regular.

Atualmente o empresário que precisa contratar serviços flexíveis por conta de necessidades empresariais enfrenta variada ordem de problemas, sendo o principal e mais comum em relação ao vínculo de emprego. Três hipóteses podem ser levantadas aqui, sob o ponto de vista empresarial, duas delas solucionáveis com a regulamentação proposta. As hipóteses são apresentadas a seguir de modo individualizado.

A primeira situação é a do empresário que opta por registrar o contrato, reconhecendo o vínculo de emprego mesmo do trabalhador que não se insere no conceito tipo de empregado. Tal hipótese seria, em tese, a melhor para o trabalhador, já que garantiria a si a mais ampla 182 ZYLBERSTAJN, Hélio. "Aspectos Econômicos da Redução da Jornada de Trabalho". in MANNRICH, Nelson et. al. (coords.). Reconstrução do Direito do Trabalho - Anais da Academia Nacional de Direito do Trabalho 2010. São Paulo: LTR, 2010, pág. 63.

${ }^{183}$ DELGADO, Gabriela Neves. Direito Fundamental ao Trabalho Digno. São Paulo: LTR, 2006, pág. 215. 
gama de direitos disponíveis no ordenamento jurídico. Seria, no entanto, injusta e economicamente a pior para o tomador de serviços, que pagaria o custo de um trabalho que efetivamente não contrataria. Apenas a título de ilustração, tal hipótese estaria configurada quando registrado como vendedor um trabalhador que efetivamente se ativasse como representante comercial autônomo, situação incomum, mas não inexistente.

A segunda hipótese é aquela onde o trabalhador, na maioria das vezes premido pela necessidade decorrente do total desamparo jurídico, busca o reconhecimento do vínculo de emprego, com adaptação, ainda que forçada, da relação jurídica mantida com o tomador de serviços. Tal situação é recorrente no mercado atual, juntamente com a terceira apontada abaixo, inclusive com reflexos intensos na Justiça do Trabalho. Exemplo prático é o de trabalhador que presta serviços sob contratação autônoma inominada, sem qualquer previsão jurídica além do pagamento das horas trabalhadas pelo preço ajustado e posteriormente pleiteia o vínculo de emprego junto à Justiça do Trabalho, sob a alegação de que o serviço se dava nos moldes previstos na Consolidação das Leis do Trabalho, conseguindo o reconhecimento de seus pedidos justamente por estar sua prestação de serviços inserida em uma área nebulosa do direito, com contornos mal definidos dos critérios que implicam no vínculo empregatício.

A terceira situação é a única que não encontra solução na proposta, mas foge aos limites da teorização jurídica. Trata-se de uso fraudulento de modalidades contratuais, seja por parte do empregado que efetivamente presta serviços autônomos, mas alega o vínculo de emprego, seja por parte do tomador de serviços que se utiliza de verdadeiros empregados sob subordinação com o disfarce de uma contratação autônoma. A hipótese, infelizmente comum, não pode ser evitada com a regulamentação de direitos mínimos em qualquer forma de trabalho, mas pode ser reduzida, vez que haverá incentivo à contratação de acordo com a realidade da prestação de serviços, de esclarecido e amparo pelo direito positivo.

Com a ressalva da particularidade das denominações empregado e empregador e trabalhador e tomador de serviços já destacada, é pertinente a lição de Arion Sayão Romita de que: "não há empresário que, por mais flexível que seja a regulação do trabalho, contrate empregados se considerar que sua presença na empresa é inútil; da mesma forma, não há 
empresário que, a despeito de toda a rigidez da lei, deixe de admitir um empregado se este for imprescindível ao sistema produtivo."184

A tese de renovação por meio da flexicurity pretende sanar a maior falha identificada nas apostas feitas exclusivamente na flexibilização. Com efeito, como bem identifica o professor italiano Mario Garofalo, a flexibilização pura e simples parte de duas premissas, a de redução de custos e a de aumento no número de empregos. Apenas a primeira acabou por se concretizar. Na lição do citado professor, em síntese, a redução de custos pode acarretar maior produtividade, considerada essa na relação entre os serviços produzidos e a quantidade de trabalho empregado, sem implicar o necessário aumento do número de trabalhadores utilizados $^{185}$.

Já a questão da flexicurity, aqui defendida, busca sempre medidas compensatórias para o trabalhador em contrapartida à flexibilidade, seja por meio de direitos a serem respeitados pelos tomadores de serviços, seja por meio de políticas estatais pró-ativas de fomento ao emprego e à empregabilidade.

Ao tratar de flexibilização, afirmou José Francisco Siqueira Neto que "não obstante a ênfase sobre a rigidez das leis trabalhistas, a experiência de mercado globalizado tem demonstrado dois importantes aspectos. De um lado, a importância da inovação produtiva, da agilidade empresarial e do compromisso com os trabalhadores para que as empresas atinjam

\footnotetext{
${ }^{184}$ ROMITA, Arion Sayão. Flexigurança - A Reforma do Mercado de Trabalho. São Paulo: LTR, 2008, pág. 79.

${ }^{185}$ No original: "si afferma l'esistenza di una correlazione positiva tra flessibilità e occupazione. Non è mai stato molto chiaro, ma sembra che il ragionamento possa essere cosi riassunto: una maggiore flessibilità del lavoro migliora la produttività e i conti economici delle imprese e, di conseguenza, aumenta la propensione delle stesse ad assumere. Concordo com la prima parte della proposizione: una maggiore disponibilità della forza lavoro alle variabili esigenze dell`organizzazione produttiva è certamente uma risorsa potenzialmente idonea ad accrescere la produttività ma non è dato intendere perchè questo dovrebbe avere effetti benefici sull’occupazione. La produttività, infatti, altro non è che il rapporto tra volume dei bei o servizi prodotti e quantità di lavoro impiegato; il suo incremento può comportare che il primo (il numeratore della frazione) rimanga immutato e diminuisca la forza lavoro impiegata (il denominatore) e, comunque, anche se il numeratore aumenta, il denominatore non aumenterà nella medesima proporzione: per raddoppiare la produzione, in presenza di um incremento della produttività dovuto a uma maggiore flessibilità della manodopera, non ocorre raddoppiare il personale occupato". GAROFALO, Mario Giovanni. "La Legge Delega Sul Mercato del lavoro: Prime Osservazioni”. in Rivista Giuridica del Lavoro, ano 54, n. 2, Roma: Ediesse, 2003, págs. 360/361.
} 
qualidade e preços nos seus produtos para inserirem-se efetivamente no cenário virtuoso da concorrência internacional. De outro lado, a relevância do papel do Estado na gestão das políticas industrial e trabalhista ${ }^{186}$ ". Embora não tratando de tema que à época nem mesmo era debatido entre os estudiosos do Direito do Trabalho, as palavras do autor demonstram que a flexicurity, como caracterizada na presente tese, com medidas que atendem interesses do capital e do trabalho com apoio de medidas estatais, constitui modo de atendimento dos principais aspectos levantados com a crise do Direito do Trabalho.

É certo, como visto, que a definição de flexicurity no direito estrangeiro envolve políticas de bem-estar social, residindo nesse ponto as principais adaptações a serem feitas à realidade nacional, juntamente com a concientização a respeito da negociação entre os atores sociais e inafastável reforma sindical. Assim, como lembrado acima por Arion Romita, o tomador de serviços irá contratar o trabalhador de acordo com sua necessidade apenas, tal fato é indiscutível. No entanto, há medidas estatais que podem ser tomadas para o fomento da empregabilidade, além do suporte ao trabalhador nos momentos de transição entre os postos de trabalho, como visto no capítulo sobre as experiências europeias da flexisegurança.

Nesse sentido, serve uma vez mais de exemplo ao direito brasileiro a experiência italiana. Com efeito, ao comentar os resultados da multiplicação de formas contratuais e reestruturação dos contratos de formação, derivados da chamada "Reforma Biagi", em grande parte flexibilizadora, Potito di Nunzio esclarece que o intuito de mitigar o desemprego estrutural pretendido pela reforma não pode ser alcançado pela normatização contratual, apenas, se não acompanhada de medidas de estímulo à formação e requalificação profissional, pública ou privada, além de uma adequada cobertura financeira. ${ }^{187}$

${ }^{186}$ SIQUEIRA NETO, José Francisco. "Desregulamentação e Flexibilização do Direito Do Trabalho - Uma Abordagem Preliminar”. in Revista Direito Mackenzie, nº 1, 2000, pág. 56.

${ }^{187}$ Nas palavras do autor: "le norme sulla riforma dei contratti a contenuto formativo che dovrebbero mitigare la disoccupazione strutturale sono valide, anche se incomplete e mal coordinate com le vecchie normative sull apprendisato e sul contratto di formazione e lavoro che non sono state interamente abrogate. Tali norme, tuttavia, non sono sufficiente se non accompagnate da una seria e impegnativa attività di formazione e riqualificazione professionale, sia pubblica che provata, sostenuta da adeguata copertura finanziaria". DI NUNZIO, Potito. "Vincoli e opportunità per le imprese nell accesso alle diverse tipologie contrattuali dopo la Riforma Biagi: una rassegna critica". in TIRABOSCHI, Michele (coord). La Riforma Biagi del Mercato del Lavoro. Milano: Giuffrè, 2004, pág. 109. 
A aplicação de medidas estatais de welfare que estimulem a inserção no mercado de trabalho, qualificação profissional e estimulem, ainda, a economia formal são possíveis soluções para o tratamento da questão relativa aos "excluídos do direito", ainda se faça uma leitura ampliativa do Direito do Trabalho. Nesse sentido a lição de Paulo Gustavo de Amarante Merçon de que "tema correlato à expansão do direito do trabalho é o da proteção social dos assim denominados excluídos. Referimo-nos especialmente àqueles que, desprovidos de educação básica e plena cidadania, alternam a situação de desempregados à de trabalhadores informais, em si hipossuficientes, ainda que não sujeitos a uma relação de trabalho. Aqui, são flanelinhas, ali, malabaristas nos sinais de trânsito, vendedores de balas nos ônibus, dentre tantos personagens da economia precária e informal." ${ }^{\text {"188 }}$

Não há que se falar em impossibilidade de custeio de uma novo Estado de bem-estarsocial. Com efeito, tratando da realidade indiana, com aspectos econômicos ainda mais complicados que os brasileiros, Praveen Jha e Sakti Golder aduzem que "o argumento de que países em desenvolvimento não podem arcar com o medidas públicas voltadas para a seguridade social e outras políticas de promoção, proteção e incentivo de trabalho é bastante fraco. De fato, a experiência do mundo desenvolvido, em especial dos países europeus no final do século XIX e primeira parte do século XX, quando com um modesta renda per capita puderam em grande número levar a efeito sistemas promocionais e protetivos de trabalho, além de gradualmente expandi-los, é bastante ilustrativa ${ }^{189}$."

As prioridades definidas na Agenda Nacional de Trabalho Decente podem ser reconhecidas como medidas de fomento caracterizadoras do elementos "segurança" da flexisegurança aqui defendida. A prioridade número um da agenda é: "gerar mais e melhores empregos, com igualdade de oportunidades e de tratamento". A de número dois: "erradicar o trabalho escravo e eliminar o trabalho infantil, em especial em suas piores formas." A

\footnotetext{
${ }^{188}$ MERÇON, Paulo Gustavo de Amarante. op. cit., pág. 92.

${ }^{189}$ JHA, Praveen; SAKTI, Golder. Labour Market Regulation and Economic Performance: A Critical Review of Arguments and Some Plausible Lessons for India. Genebra: OIT, 2008, pág. 34. Disponível em http://www.ilo.org/wcmsp5/groups/public/---ed_emp/---emp_elm/---analysis/documents/ publication/wcms_ 113926.pdf (último acesso em 28/12/2012).
} 
prioridade três, por fim, é: "fortalecer os atores tripartites e o Diálogo Social como um instrumento de governabilidade democrática. ${ }^{190}$.

Com relação ao seguro-desemprego e a medidas de realocação profissional, em que pese a propaganda governamental de que o país é um dos poucos da América Latina a dispor, por exemplo, de um sistema de seguro-desemprego, como já citado anteriormente no texto ${ }^{191}$, o fato é que tal sistema não é suficiente para garantir a empregabilidade, justamente por ser voltado somente ao empregado clássico, e não ao trabalhador hipossuficiente em geral. Com efeito, é requisito essencial para a concessão do seguro-desemprego a anotação do contrato de trabalho em Carteira Profissional, ter recebido salários consecutivos, no período de 6 meses anteriores à data de demissão e ter sido empregado de pessoa jurídica, por pelo menos 6 meses nos últimos 36 meses. $^{192}$

Ademais, nenhuma política de seguro-desemprego pode ser desenvolvida a contento de modo desvinculado de um inteso programa de requalificação profisssional e incentivo à busca de novos postos de trabalho, sob pena de se incentivar o ócio remunerado. Afirma a esse respeito José Paulo Zeetano Chahad que "tem sido amplamente comprovado, inclusive na literatura internacional, que "a introdução do seguro-desemprego como mecanismo de garantia de renda durante o desemprego, altera bastante o comportamento do trabalhador, pela existência do chamado "risco moral" (moral hazard). Ou seja, como ocorre em qualquer mercado onde se introduz um seguro, o comportamento do seu beneficiário torna-o menos cauteloso com a ocorrência do sinistro ou do evento. No caso do seguro-desemprego, existe um substancial conjunto de estudos revelando que o desempregado torna-se menos ativo na

\footnotetext{
${ }^{190}$ MINISTÉRIO DO TRABALHO E EMPREGO. Agenda Nacional de Trabalho Decente. Brasília: 2006, págs. $10 / 11$.

${ }^{191}$ ORGANIZAÇÃO INTERNACIONAL DO TRABALHO. op. cit., págs. 49/83.

${ }^{192}$ Deve ser reconhecido que algumas, poucas e insuficientes, hipóteses extras de pagamento do benefício do seguro-desemprego foram sendo instituídas ao longo do tempo, tal seja: o pagamento ao trabalhador doméstico desde que inserido no sistema do Fundo de Garantia do Tempo de Serviço por um período mínimo de quinze meses; ao empregado cujo contrato de trabalho foi suspenso em virtude de participação em curso ou programa de qualificação oferecido pelo empregador (hipótese do artigo 476-A da CLT, pouquíssimo utilizado no país); a pescadores profissionais durante o período em que a pesca é proibida devido à procriação das espécies e a trabalhadores resgatados da condição análoga à de escravidão.
} 
busca por emprego, tenta protelar seu reemprego e, com isso, acaba afetando a taxa de desemprego"193.

Pelo que se expôs, a contratação do trabalho pelo tomador de serviços se dá pela vontade/necessidade empresarial, com o fator de influência do Estado dependendo da intensidade das políticas estatais de fomento ao emprego e empregabilidade, aliada, ainda, à intensidade da busca do novo posto pelo trabalhador, de acordo com os programas de formação profissional. A forma como esse trabalho será contratado dependerá, ainda, das vantagens econômicas e necessidades empresariais.

A existência de regulamentação legal específica para outras formas de trabalho, além de contribuir para a melhoria das condições pessoais dos verdadeiros trabalhadores autônomos e atípicos, constituirá medida para o combate da temida e já lembrada fraude trabalhista. Com efeito, como aponta Roberto Davis “aparentando a relação de emprego mera relação de trabalho, eventual ou autônoma, ou se achando ela disfarçada, escondida ou ocultada sob falsos pretextos, que escondam algum ou todos os requisitos da sua conceituação legal, definidos no art. $2^{\circ}$ da CLT, induzindo sua inexistência, poderá afastar do empregador não somente os encargos da legislação trabalhista, como, também, aqueles constantes das normas inseridas nas leis de Previdência Social e tributária. ${ }^{194 "}$ Já com a legislação que regule efetivamente as formas de trabalho que não a de emprego, inserindo esses trabalhadores em situações jurídicas protetivas efetivamente, ocorrerá um desestímulo para a fraude trabalhista e a contratação de trabalho informal ou desregulamentado.

A necessidade de formalização do trabalho também é lembrada por Rodrigo Goldschmidt ao aduzir que "a afirmação do trabalho, principalmente do trabalho formal, constitui, pois, elemento fundamental para a inclusão social e a melhor distribuição de renda. Em outras palavras, as políticas públicas de emprego e a regulação do trabalho formal, papéis esses afetos ao Estado, são necessárias não só para afirmar a dignidade da pessoa humana, mas

193 CHAHAD; José Paulo Zeetano. Flexibilidade no mercado de trabalho, proteção aos trabalhadores $e$ treinamento vocacional de força de trabalho: a expêriencia de América Latina e perspectivas (Análise do caso brasileiro). Santiago: ILO, 2009, pág. 120. Disponível em http://www.eclac.org /publicaciones/xml/0/35960/DOC_W_246_Chahad.pdf (último acesso em 12/01/2013).

${ }^{194}$ DAVIS, Roberto. "Dissimulação Do Contrato De Trabalho - Algumas Espécies”. in Síntese Trabalhista, $\mathrm{n}^{\circ}$ 113, novembro de 1998, pág. 7. (versão digital). 
também para assegurar o desenvolvimento firme e consistente da economia do país, numa espiral positiva e crescente, redundando em benefícios para todos os envolvidos: trabalhadores, empresas e Estado." 195

Aumentar a regulamentação do trabalho em geral, o autônomo e possivelmente o parassubordinado, por exemplo, não quer dizer extinguir o trabalho subordinado, tampouco diminuir sua esfera de atuação. Como visto, há espaço para a coexistência de ambos no âmbito do mercado de trabalho. O empresário que necessita de trabalhador inserido em suas atividades essenciais, cumprindo horários pré-determinados com habitualidade e submetido ao Poder Diretivo, continuará a se utilizar de empregados em sentido clássico. Caso venha a contratar trabalhadores apenas formalmente autônomos para reduzir custos de produção, continuará a infringir a Lei e a Justiça do Trabalho continuará apta a enfrentar a fraude com o reconhecimento do vínculo de emprego. Situação diversa é a do empresário que necessita de um serviço específico de modernização de seu sistema informatizado, por exemplo, quando esse não é o ramo de atividades de sua empresa. Poderá, em tal caso, contratar prestadores de serviço, pessoa física, sem vínculo de emprego para trabalhar por tempo determinado, ainda que dentro de suas dependências, com orientações de serviço e por período mais ou menos longo, sem que isso implique em reconhecimento do vínculo de emprego. Em contrapartida, o trabalhador estaria protegido pela aplicação ao menos do núcleo mínimo de normas trabalhistas sugerido, com limitação de jornada, piso remuneratório, medidas de segurança e higiene do trabalho, dentre outros indicados no capítulo anterior. Ademais, finda a prestação de serviços para determinado tomador, o trabalhador contaria com as medidas estatais de fomento à empregabilidade para se realocar no mercado de trabalho.

Pode-se concluir, assim, que o modelo de flexicurity a ser implementado no país deve ser tripartite, contando com a participação de todos os atores do pacto-social: empresários, trabalhadores (com a assistência de suas entidades sindicais) e o Estado. Cada um dos atores sociais tem papéis a cumprir para o sucesso da modernização do Direito do Trabalho.

O modelo deve ser fundado, de uma lado, na flexibilidade do mercado de trabalho, não com relação à facilidade da dispensa, que já existe em território brasileiro, mas sim no que diz respeito à ampliação das hipóteses de uso de contratos por prazo determinado e contratos

\footnotetext{
${ }^{195}$ GOLDSCHIMIDT, Rodrigo. o.p. cit., pág. 155.
} 
atípicos de trabalho, incluindo a terceirização de serviços, bem como na regulamentação específica das formas de trabalho autônomo. A flexibilidade do mercado atende aos interesses empresariais de adaptação à crise, com o fomento da produtividade e diminuição de custos.

De outro lado, as mudanças acima que conferem maior flexibilidade ao mercado, devem ser acompanhadas de medidas que garantam a dignidade dos trabalhadores. Nesse aspecto, a regulamentação das formas de trabalho autônomo, da terceirização de mão-de-obra e do uso de contratos atípicos, deve prever a aplicação de, no mínimo, o rol essencial de direitos devidos a todos os trabalhadores, como definido no capítulo anterior, além de outros que possam ser destinados a cada forma de trabalho, considerando-se as particularidades de cada caso. A ampliação da proteção do trabalhador, independentemente da forma de contratação, protege o ser humano que trabalha das implicações decorrentes da flexibilização do mercado de trabalho e das demais adaptação econômicas em face da crise. Como contraprestação pelo mercado flexível, as empresas devem arcar com o mínimo de direitos aptos a garantir a dignidade dos trabalhadores em sentido amplo.

Para completar o triângulo, são necessárias medidas estatais de garantia da segurança dos trabalhadores. Essas medidas, conforme debatido ao se tratar dos aspectos gerais da flexicurity, devem envolver políticas pró-ativas de emprego que promovam a empregabilidade, como cursos de formação, requalificação e recolocação profissional, além de benefícios de proteção financeira referente aos períodos de não-trabalho (e.g. o seguro-desemprego, desde que com aplicabilidade muito mais ampla do que o benefício atual). O papel do Estado no desenvolvimento de um sistema de flexicurity é de vital importância e não se limita, de modo algum, à produção legislativa, devendo ser ativo nas políticas de fomento à empregabilidade. A delicada questão do custeio não pode ser vista como obstáculo intransponível para se atingir os resultados, sendo que as atuais políticas governamentais de distribuição de renda possuem um custo ainda mais alto, sem vinculação com a necessária proteção do trabalhador e não estão relacionadas a fontes específicas de custeio, enquanto que as idéias aqui propostas poderão ser financiadas por contribuições vinculadas à própria contratação do trabalho.

A doutrina estrangeira também tem se preocupado com o papel da flexicurity na coexistência das necessárias adaptações de contratos flexíveis com a expansão da esfera de aplicação do Direito do Trabalho para além do contrato de emprego. Nesse sentido, Giuseppe 
Bronzini apresenta como resumo de artigo publicado o "exame do papel que os princípios comuns da flexicurity deveriam ter na limitação da ação de contratos atípicos, ao mesmo tempo em que afirma que uma estratégia autêntica de flexicurity deve basear-se em direitos de 'nova geração' que tutelem os sujeitos independentemente do contrato de emprego, em primeiro lugar com uma 'renda base` garantia diretamente pela União Europeia." 196 (tradução livre).

Em suma, pregar a aplicação da flexicurity no direito pátrio como modo de expansão da proteção justrabalhista implica defender uma ampla reforma no sistema jurídico, em especial do Direito do Trabalho. Não se trata, certamente, de tarefa simples, uma vez que a reforma deve atingir uma ampla gama de aspectos, com a adaptação de institutos jurídicos já existentes e a criação de outros inéditos no ordenamento nacional.

A reforma não se dará sem percalços e certamente provocará discussões e animosidades. Como aponta Hélio Zylberstajn "falou-se em transição, e de fato esse vai ser o grande problema de todas as reformas que nós teremos que fazer, inclusive a das relações de trabalho. Como avançar sem abrir mão daquilo que já se tem? Como chegar a um novo modelo preservando as garantias que estão na lei, na Constituição? Para cada interlocutor essas garantias têm um sentido diferente. ${ }^{197}$,

Como já ressaltado em tópico anterior, a reforma do sistema sindical pátrio constitui elemento chave para o desenvolvimento de um modelo nacional de flexicurity. Com efeito, em se tratando de uma relação tripartite, com participações efetivas de trabalhadores, empresários e do Estado, é indiscutível o relevante papel a ser desempenhado pelas entidades sindicais em todas as suas esferas. O Sindicato e suas entidades superiores, são as únicas entidades capazes

${ }^{196}$ No original: Si esamina il ruolo che i principi comuni di flexicurity dovrebbero avere nel limitare l'adozione di contratti atipici, ma si afferma che una strategia autentica di flexicurity dovrebbe basarsi su diritti di " nuova generazione" che tutelano i soggetti indipendentemente dal contratto di lavoro, in primo luogo da un basic income garantito direttamente dall'unione europea" BRONZINI, Giuseppe. "Come evitare la " segmentazione" del mercato del lavoro: la filosofia europea della flexicurity e i contratti a termine". in D. \& L - Rivista Critica di Diritto del Lavoro, n. 4, outubro/dezembro de 2008.

${ }^{197}$ ZYLBerstajN, Hélio. Novos Padrões de Negociação Coletiva: Perspectivas do Contrato Coletivo de Trabalho no Brasil. Painel de Debates coordenado por Marco Antônio de Oliveira. Disponível em http://www.cebrap.org.br/v1/upload/biblioteca_virtual/NOVOS_PADROES_DE_NEGOCIACAO_COLETIVA PERSPECTIVAS.pdf (último acesso em 03/01/2013). 
de representar coletivamente os interesses diretos dos trabalhadores que, historicamente, não possuem efetivo poder de barganha quando tratados individualmente.

Há que se lembrar que a questão sindical envolvendo as políticas de flexicurity não foi tratada a contento nem mesmo no âmbito da União Europeia onde surgiram discussões a respeito do instituto. Nesse diapasão, alerta o professor espanhol José Antonio Fernández Avilés que "especialmente no livro verde"198 a "modernização do Direito do Trabalho se apresenta em vertente flexibilizadora e 'individualista', não se faz referência à 'dimensão coletiva` que é parte estrutural do mesmo. Não se atende ao conflito social e aos instrumentos de articulação e representação dos interesses coletivos e aos instrumentos de ação presentes nos sistemas democráticos de relações de trabalho. Quando aparece, a negociação coletiva é referida simplesmente como um instrumento de regulação, mas sem se atentar à sua natureza de processo de intercâmbio e de diálogo entre sujeitos coletivos que proporciona uma redistribuição do poder nas relações de trabalho (com uma função de emancipação e niveladora da desigualdade social) que pode facilitar a flexibilidade em um amplo grupo de temas. ${ }^{199}$

198 A esse respeito, consultar o capítulo dedicado ao estudo global da flexicurity e seu desenvolvimento no continente europeu.

${ }^{199}$ No original: "especialmente em el Libro Verde la "modernización" del Derecho laboral se presenta en clave flexibilizadora e "individualista", no se hace referencia a la "dimensión colectiva" que forma parte estructural del mismo. No se atiende al conflicto social y a los instrumentos de articulación y representación de los intereses colectivos y a los instrumentos de acción presentes en los sistemas democráticos de relaciones laborales. Cuando aparece la negociación colectiva, es referida simplemente como instrumento de regulación, pero sin atenderse a su naturaleza de proceso de intercambio y de diálogo entre sujetos colectivos que proporciona una redistribución del poder en las relaciones de trabajo (con una función emancipatoria y niveladora de la situación de desigualdad social), así como puede facilitar la flexibilidad en un amplio grupo de materias." FERNANDEZ AVILÉS, José Antonio, El Modelo de "Flexiseguridad" Europeo: Una Aproximación Crítica. Palestra proferida no X Congresso Europeu de Direito do Trabalho e da Seguridade Social em Sevilha de 21 a 23 de setembro de 2011, págs. 17/18. Disponível em http://www.europeanrights.eu/public/commenti/fernandez_alviles_testo.pdf (último acesso em 02/01/2013). 


\section{CONCLUSÕES}

O mundo atual, em seus mais diversos aspectos, é cada vez mais dinâmico. Transformações relevantes ocorrem diuturnamente impactando as esferas político-econômicosociais de todos e de modo progressivamente interligado. O multifacetário fenômeno da globalização faz com que, exemplificativamente, uma alteração em um sistema econômico de um país do sudeste asiático reflita imediatamente nas bolsas de valores da América do Norte. Não se pode viver isolado ou alheio às transformações de todas as ordens, sob pena de se ver deslocado de forma anacrônica do sistema global de produção e distribuição de bens.

Os impactos da globalização são sentidos, desse modo, em todos os elementos da vida cotidiana. É no setor econômico, no entanto, que a globalização resta mais evidente, ampliando mercados a uma dimensão jamais vista e revolucionando o sistema produtivo, ignorando fronteiras e impondo desafios regulatórios que vão desde regras de comércio internacional a normas societárias, fiscais e trabalhistas.

Ocorre que as mudanças do mundo moderno não geram apenas resultados positivos. $\mathrm{O}$ dinamismo inédito dos mercados implicou a geração de grandes riquezas, mas também impulsionou o sistema capitalista em crises cíclicas cada vez mais frequentes. Em que pese a aparente contradição das crises econômicas decorrentes de transformações que buscavam maiores ganhos, o fato é que se tornaram imprescindíveis medidas de adaptação e enfrentamento da crise para que se possa retomar o equilíbrio nas relações produtivas que, ainda que se negue como o fazem certos críticos do capitalismo, regem o mundo atual.

As crises econômicas, como visto ao longo da tese, são cada vez mais frequentes e severas. As respostas para o enfrentamento a contento devem ser também dinâmicas e profundas, sendo necessário sempre levar em consideração que o bem maior a ser tutelado é a dignidade do ser humano, sem a qual perde qualquer sentido a busca pelo bem-estar material.

A questão do trabalho humano, que integra o objeto desse estudo, também não está fora do turbilhão de mudanças decorrentes da globalização e das sucessivas crises econômicas. O sistema produtivo capitalista está em constante alteração, devendo se adaptar à nova realidade globalizada. Em que pese o crescimento do capitalismo financeiro e especulativo, o trabalho continua a ser elemento central do processo produtivo, quer se veja o trabalho como 
fator de custo econômico, quer se considere esse instrumento de dignificação e valorização da pessoa humana.

Os impactos da globalização e das crises econômicas sobre o trabalho são de grandes proporções e de variadas ordens. Muito se debateu e continua-se a discutir a respeito do fim dos empregos e da decadência do modo de vida fundado no trabalho. Como se afirmou ao longo do texto, não se concorda com a visão apocalíptica, mas isso não quer dizer que as formas de trabalho e o modo como esse é visto não devam sofrer adaptações.

O trabalho humano continua a ser fundamental dentro do sistema capitalista de produção. No entanto, o modo como esse trabalho é necessário não é mais o mesmo de duzentos anos atrás, tampouco de duas ou três décadas. O contrato de trabalho subordinado por prazo indeterminado que tão bem se encaixava dentro da linha de montagem do sistema fordista de produção ainda existe e em grande escala, mas não responde mais à totalidade das necessidades empresariais e tampouco dos próprios trabalhadores.

O mercado de trabalho foi profundamente transformado nos últimos anos e com ele, do mesmo modo, alterada a forma de utilização das diversas modalidades de prestação de serviços. Ganha força cada vez maior o sistema de produção just in time, onde o processo produtivo acompanha em tempo real as necessidades de cada módulo da cadeia de montagem e as demandas dos clientes. As empresas passam a buscar trabalhadores cada vez mais especializados e disponíveis para atender a pedidos de acordo com o tempo e a demanda. Por outro lado, os trabalhadores continuam a necessitar dos frutos do trabalho para sua sobrevivência e a submissão da prestação de serviços meramente às leis da oferta e da procura que regulam o mercado implicaria a ruína paulatina da classe trabalhadora.

Dentro desse cenário de tormentosas mudanças envolvendo o sistema produtivo e o mercado de trabalho, cresce a importância da releitura do papel do Direito do Trabalho e como esse deve se adaptar em face das crises que enfrenta.

O escopo primário do Direito do Trabalho deve ser o de garantir um patamar mínimo de dignidade para todo o ser humano que trabalha. A ciência juslaboral deve regular as relações de trabalho, mais precisamente as relações entre capital e trabalho (com as exceções já tratadas no texto, como a referente ao trabalho doméstico que não é voltado diretamente ao 
sistema de produção capitalista) e não servir como instrumento de protecionismo ao empregado subordinado, apenas.

Embora o alerta conste em diversos pontos da tese, cabe frisar, uma vez mais, que não se pretende a redução dos direitos conquistados pelos empregados clássicos, em situação de subordinação. Não se prega a desregulamentação, tampouco se acredita que são excessivamente onerosos os direitos de tal classe trabalhadora. O que se afirma é que existem outras formas de trabalho, que continuarão a existir independentemente da evolução do direito voltado aos empregados e que essas formas de trabalho necessitam de proteção jurídica e de reconhecimento formal do estado para serem exercidas.

O Direito do Trabalho não pode ser discriminatório. É certo que não constitui discriminação tratar desigualmente aqueles que estão em condições de desigualdade. No entanto, tutelar apenas alguns trabalhadores, no caso o empregado clássico caracterizado, dentre outros elementos, pela subordinação jurídica, ao passo que todo os demais trabalhadores ficam relegados à própria sorte, constitui, sim, discriminação incabível. Não se propõe que empregados devam ter exatamente os mesmos direitos de trabalhadores autônomos, por exemplo, mas sim que esses trabalhadores autônomos também devem merecer a atenção do Direito do Trabalho para receber o mínimo de proteção jurídica capaz de lhes garantir a existência digna por meio do trabalho.

O moderno papel do Direito do Trabalho deve se deslocar do protecionismo ao empregado para o conceito maior de proteção do trabalhador em sentido amplo. Não se pode ignorar a existência de outras formas de trabalho que não a relação de emprego, tampouco pode-se desenvolver um raciocínio como se fosses irrelevantes as demais modalidades de labor. Devem ser tuteladas pelo direito todas as formas de trabalho onde o prestador de serviços esteja, de alguma forma, em situação de inferioridade, em uma releitura do clássico conceito de hipossuficiência do trabalhador.

O empregado, o trabalhador classicamente subordinado, há muito deixou de ser o único que se encontra em situação de inferioridade em face do capital. A relação entre capital e trabalho é, na imensa maioria das vezes, uma relação jurídica desequilibrada pendente para o lado empresarial. Todo aquele que coloca seus serviços à disposição da atividade produtiva alheia está em condições inferiores dentro de uma relação jurídica trabalhista. Ainda que o 
trabalho seja prestado de modo autônomo, é o tomador de serviços que decidirá quando contratar e serão as suas necessidades e a sua vontade que determinarão o contrato. $\mathrm{O}$ trabalhador pode supostamente ter autonomia para fixar preços, condições e tempo de trabalho, mas somente o fará se houver demanda empresarial que o comporte. Nesse contexto, foi desenvolvida a teoria do trabalho semi-dependente, bem como do parassubordinado e do trabalho autônomo dependente. Assim, salvo as exceções onde a figura do capital e do trabalho se misturam na do empreendedor autônomo (como a do profissional liberal que coordena o próprio negócio, como visto no texto), é certo que as relações entre capital e trabalho se dão em condições de hipossuficiência para o trabalhador que necessita de algum grau de proteção jurídica que deverá ser fornecido pelo Direito do Trabalho.

A regulamentação jurídica deve ser sempre adequada ao problema social que se coloca. Como visto, a existência de múltiplas formas de trabalho humano é uma realidade. As necessidades econômicas atuais demandam a utilização cada vez mais intensa de modalidades contratuais flexíveis e de formas de trabalho estranhas à relação de emprego. Com o devido respeito aos que pensam de modo diverso, a solução para a questão dentro do Direito do Trabalho não está no alargamento do conceito de subordinação jurídica ou na interpretação ampliativa dos requisitos para o reconhecimento do vínculo empregatício, mas sim na existência de um arcabouço jurídico próprio para tutelar outras modalidades de prestação de serviços.

Não se pode querer considerar como de emprego uma relação jurídica que não o é. Aumentar o alcance da subordinação ou afrouxar os requisitos da relação de emprego oferecerá uma solução artificial para o problema, com a aplicação de normas jurídicas voltadas a uma determinada realidade a outra distinta e dotada de características peculiares. A ausência de disciplina específica para outras formas de prestação de trabalho e a tentativa de se inserir todas as relações jurídicas trabalhistas dentro da esfera da relação de emprego tem por consequência uma precarização ainda maior das condições daqueles que trabalham sem vínculo de emprego, por ficarem à margem proteção do direito, bem como um crescimento do uso de medidas fraudulentas tanto por trabalhadores que atuam em condições de autonomia e pleiteiam direitos empregatícios, quanto por empresários que se utilizam de formas de trabalho sem regulamentação legal para diminuir os custos produtivos. 
Pode-se concluir, portanto, que o Direito do Trabalho tradicional fundamentado em um sistema de proteção do trabalhador subordinado contratado por prazo indeterminado, o empregado clássico, está em crise. A crise da ciência juslaboral se identifica a partir do momento em que o conjunto de normas e princípios que a integra não mais é suficiente para atender ao seu objetivo, tal seja o de garantir condições dignas de vida aos trabalhadores. $\mathrm{O}$ Direito do Trabalho não surgiu para atender aos anseios dos empregados, nasceu para dar suporte aos trabalhadores. Ocorre que ao se desenvolver, a classe trabalhadora que demandava proteção jurídica era constituída basicamente por empregados, inseridos no sistema produtivo fordista. No entanto, com as transformações que se sucederam e continuam a acontecer, o universo do ser humano que trabalha em condições de hipossuficiência se expandiu muito, ao passo que o Direito do Trabalho, em especial o brasileiro, continuou com suas atenções voltadas exclusivamente à figura do empregado. Um Direito do Trabalho que regula somente a relação de emprego é insuficiente e, portanto, está em crise. A crise jurídica em tela somente pode ser superada com a adaptação do Direito do Trabalho à realidade moderna de modo intenso, implicando a mudança de paradigma do protecionismo do empregado para a proteção do trabalhador em sentido amplo.

Constituem fatos inegáveis, portanto, a necessidade de proteção mais ampla do trabalho humano de forma a abarcar outras relações que não a de emprego, bem como a demanda empresarial voltada a formas flexíveis de trabalho como modo de enfrentamento das sucessivas crises econômicas.

O movimento de flexibilização do Direito do Trabalho não é fenômeno exclusivo brasileiro. Pelo contrário, foi no direito europeu que a tendência foi identificada e propagada como possibilidade de enfrentamento das dificuldades financeiras, chegando-se até mesmo a falar em um Direito do Trabalho excepcional “de crise". No âmbito pátrio, a flexibilização tomou corpo juntamente com medidas ditas neoliberais em face das conseqüências dos períodos de crise econômica.

As discussões a respeito da flexibilização são sempre circundadas de forte caráter ideológico, sendo que muitas vezes o foco do debate foge da demanda pela adaptação do Direito do Trabalho para a politização entre direita e esquerda; e liberalismo e intervencionismo social. Desse modo, radicalizaram-se posicionamentos onde a maior parte da 
doutrina juslaboral vê a flexibilização como modo de precarização dos direitos dos trabalhadores, não havendo nada de positivo e a outra parte enxerga as medidas flexibilizadoras e até desregulamentadoras como um bálsamo capaz de solucionar todos os problemas decorrentes da crise, reduzindo drasticamente o "custo-trabalho" no sistema produtivo.

A flexibilização do Direito do Trabalho não pode e não deve ser confundida com precarização de direitos, como foi frisado ao longo do texto. Não pode e não deve, também, ser identificada como fórmula mágica para a solução da crise. A flexibilização deve ser encarada como mais uma ferramenta, embora essencial, para a adaptação do Direito do Trabalho à atual realidade econômica-jurídica-social, mas que deve ser utilizada sem se perder de vista que o fim do Direito do Trabalho é a tutela do trabalhador e não da produção econômica com os menores custos possíveis.

Necessário se faz, portanto, que as adaptações do Direito do Trabalho por meio de inevitáveis reformas de flexibilização sejam acompanhadas de medidas protetivas aos trabalhadores que lhes garantam a segurança, ainda que não no mesmo emprego ou posto de trabalho.

Todo trabalhador que desenvolva sua atividade em prol da atividade econômica alheia demanda, assim, alguma forma de proteção jurídica. O Direito do Trabalho deve assegurar a todos os trabalhadores um núcleo mínimo de direitos que poderá se desenvolver mais ou menos conforme o grau de necessidade de cada classe trabalhadora (empregados, autônomos, trabalhadores inseridos em modalidades contratuais atípicas etc.).

Nesse contexto, desenvolveu-se na Europa o conceito de flexicurity analisado ao longo da tese. A preocupação das políticas de flexicurity (utiliza-se o termo 'políticas' ante a constatação de que a flexicurity se reveste de múltiplas facetas que não a enquadram em um único instituto) é justamente a conciliação de duas figuras aparentemente antagônicas: flexibilidade do mercado de trabalho e segurança dos trabalhadores.

A flexicurity surgiu na Dinamarca, sendo adotada posteriormente pela Holanda e propagada para o resto da Europa, tendo se tornado uma das bandeiras da Comunidade Europeia em termos de modernização do Direito do Trabalho. São as mais diversas as medidas 
tomadas pelos Estados europeus que são enquadradas em políticas de flexicurity, sendo que essa pode ser definida, em termos globais, apenas em linhas e princípios gerais.

Os resultados das políticas de flexicurity ainda são incertos. Pode-se falar em grande sucesso em seu país de origem, a Dinamarca, mas os indicadores são ainda discretos em países como a Espanha que não tem conseguido enfrentar o problema do desemprego entre jovens. No entanto, as ideias gerais da flexicurity representam plenamente os ideais a serem perseguidos pela necessária reforma do Direito do Trabalho, consubstanciados no incremento de formas flexíveis de prestação de serviços que atendam às necessidades empresariais modernas, ao mesmo tempo em que se tutela o trabalhador, garantindo-lhe a segurança e o bem-estar que devem decorrer de seu trabalho como fonte de subsistência. Desse modo, é extremamente relevante para o direito brasileiro o estudo da flexicurity e a análise da viabilidade de aplicação de seus conceitos ao ordenamento jurídico pátrio.

O direito brasileiro não adota, até o presente momento, qualquer linha de desenvolvimento, teórico ou prático, voltado para a flexicurity. Pode-se dizer que há medidas estatais pátrias que se inserem, de um modo ou de outro, no conceito de "flexsegurança", mas sem a preocupação de sistematizar tais medidas dentro de uma política nacional de flexicurity.

A ausência de pesquisas aprofundadas a respeito da flexicurity em território nacional (verifique-se a parca produção bibliográfica pátria a esse respeito citada ao longo da tese) pode ser atribuída em parte ao citado preconceito com relação ao termo flexibilização e em parte à ideia, que se defende equivocada, de que são intransponíveis para a realidade brasileira medidas tomadas em países tão diversos como os escandinavos. Procurou-se demonstrar na tese, no entanto, que é possível a aplicação dos conceitos da flexicurity ao direito brasileiro, desde que efetuadas as adaptações necessárias que não são, de todo modo, inexequíveis.

$\mathrm{O}$ mercado de trabalho do país já é extremamente flexível no tocante à liberdade de despedimento (com as ressalvas anteriormente feitas à questão da despedida coletiva), um dos pontos de maior controvérsia no direito europeu, onde se critica a excessiva rigidez das normas limitadoras da dispensa. Isso não quer dizer, no entanto, que não haja necessidade de flexibilização de outros aspectos do Direito do Trabalho nacional. Necessária se faz a abertura do Direito do Trabalho a figuras que até então são ignoradas pelo ordenamento jurídico, como o trabalhador autônomo e o trabalhador autônomo semi-dependente, e que constituem 
relevante parcela da atividade laborativa, tanto da existente atualmente, quanto da que se faz necessária para o desenvolvimento das atividades empresariais nos períodos modernos.

Deve-se enfrentar a problemática da crise do Direito do Trabalho por não mais ser suficiente como modo de promoção da dignidade do ser humano que trabalha. Identificou-se que o mercado de trabalho moderno demanda cada vez mais formas flexíveis de prestação de serviços que existirão quer seja feita a formalização pelo ordenamento jurídico, quer não. Verificou-se que as formas flexíveis de trabalho não podem ignorar a necessidade de proteção jurídica do maior número possível de trabalhadores que atuem em situação de inferioridade nas relações com o capital, aos quais deve ser assegurado, ao menos, um núcleo essencial de direitos.

Desse modo, o estudo das tipologias contratuais flexíveis demonstrou que são possíveis diversas adaptações do Direito do Trabalho para regular atividades de modo a atender interesses diversos de trabalhadores e empresários, mas que a adoção da flexibilização por si só acaba por gerar um desequilíbrio ainda maior nas relações de trabalho, em prejuízo sempre para o lado mais fraco, o do trabalhador. As medidas de flexibilização, desse modo, não podem ser desacompanhadas de formas de proteção jurídica do trabalhador em sentido amplo.

A solução proposta para se atingir a todos os pontos descritos anteriormente foi a adoção de um modelo nacional de flexicurity onde haja a combinação triangular de elementos flexíveis de trabalho, com regulamentação legislativa pormenorizada de tipologias contratuais atípicas e da forma de utilização do trabalho autônomo e terceirizado; combinada com o desenvolvimento de medidas de segurança ao trabalhador consubstanciadas em providências estatais de bem-estar social para períodos de inatividade como a remuneração de períodos de "não-trabalho", a promoção de cursos de formação continuada e o desenvolvimento de políticas de recolocação no mercado de trabalho; finalizada pela construção de um arcabouço jurídico que proteja todas as formas de trabalho utilizadas (e não somente a relação de emprego) com um núcleo mínimo de direitos fundamentais do trabalho que possam garantir o desenvolvimento da dignidade da pessoa humana que trabalha.

O modelo de flexicurity proposto demandará intensa reforma legislativa e mudança nos próprios paradigmas do Direito do Trabalho, mas é plenamente possível a sua implementação. A reforma, embora complexa, apresentará vantagens a todas as partes envolvidas, 
empresários, trabalhadores e o próprio Estado. Aos empresários será consentida a utilização das tão almejadas formas flexíveis de trabalho de modo formal e regular, afastando as contingências trabalhistas decorrentes de fraudes e atendendo aos anseios da produção em sistema just in time. Aos trabalhadores será concedida proteção jurídica em forma de direitos assegurados no decorrer da relação de trabalho e suporte para manutenção em períodos de "não-trabalho" e rápido retorno ao mercado. Ao Estado se concretizará o anseio de promoção da dignidade humana e dos valores do trabalho e da livre iniciativa, com apaziguamento da questão social e a busca do pleno emprego.

Dessa forma, os contornos de uma satisfatória política de flexicurity que garanta mercados de trabalho flexíveis e a garantia da segurança dos trabalhadores por meio da expansão dos direitos mínimos fixados em um rol comum que deve partir do trabalho já desenvolvido no artigo $7^{\circ}$ da Constituição Federal, em sua leitura à luz da teoria geral dos direitos fundamentais.

Não se apresentam todas as reformas legislativas que se farão necessárias para a consecução de um modelo brasileiro efetivo de flexicurity. A contribuição à ciência jurídica brasileira está na demonstração das linhas gerais que deverão nortear a criação e o desenvolvimento do modelo, fundamentado nos valores assegurados pela Constituição Federal e na transposição das experiências e estudos desenvolvidos em outros países, com as necessárias adaptações.

Um sistema jurídico nacional específico de flexicurity que se preocupe com os mercados flexíveis e com a atenção voltada à concessão de um núcleo mínimo de direitos a todos os trabalhadores em sentido amplo, bem como na atuação estatal para a garantia da segurança do ser humano que trabalha, permitirá ao Direito do Trabalho superar as crises econômicas e a sua própria crise jurídica, transformando o seu objeto de "protecionismo do empregado" em "proteção do trabalhador" como promoção do bem maior da dignidade humana.

Não se pode deixar de mencionar que a reforma legislativa necessária para a adaptação do Direito do Trabalho brasileiro ao modelo de flexicurity deverá passar por uma imprescindível reestruturação do sistema sindical. Somente em um contexto de efetiva liberdade sindical e com entidades que realmente representem os interesses de trabalhadores e 
empresários, poder-se-á falar no diálogo social necessário para o debate acerca da flexibilização das condições de trabalho com a contrapartida de medidas de expansão dos sujeitos do Direito do Trabalho e de segurança para o trabalhador.

Por fim, impende destacar que a tese desenvolvida se insere na linha de pesquisa do Departamento de Direito do Trabalho e Seguridade Social da Faculdade de Direito da Universidade de São Paulo intitulada "direitos sociais no contexto dos direitos humanos" e especificamente no projeto acadêmico "a eficácia dos institutos, normas e princípios de direito interno, comunitário e internacional do trabalho e a efetivação dos direitos humanos". Com efeito, a proposta de mudança de paradigma do Direito do Trabalho da figura do empregado para a proteção do trabalhador por meio da aplicação de uma efetiva política de flexicurity permite que o trabalhador em sentido amplo seja alcançado pelo manto do direito anteriormente destinado apenas a uma parcela da população obreira (empregados), efetivando o direito humano fundamental de valorização do trabalho como forma de dignificação da pessoa humana que labora. 


\section{BIBLIOGRAFIA}

ALLAMPRESE, Andrea. "Lavoro Ripartitto". in VALLEBONA, Antonio (coord.). I Contratti di Lavoro. Torino: UTET, 2009. Tomo II.

AMARAL, Júlio Ricardo de Paula. "Os Direitos Fundamentais e a Constitucionalização do Direito do Trabalho". in Direitos Sociais na Constituição de 1988 - Uma análise crítica vinte anos depois”. São Paulo: LTR, 2008.

ANDRADE, Everaldo Gaspar Lopes de. Direito do Trabalho e Pós-Modernidade Fundamentos para uma Teoria Geral. São Paulo: LTR, 2005.

ANTUNES, Ricardo. Adeus ao Trabalho - ensaio sobre as metamorfoses e a centralidade no mundo do trabalho. 15 a ed.. São Paulo: Cortez, 2011.

ARAUJO, Francisco Rossal de. "O Direito do Trabalho e o Ser Humano". in Síntese Trabalhista. $\mathrm{n}^{\circ}$ 114, dezembro de 1998.

ARRUDA, Kátia Magalhães. Direito Constitucional do Trabalho: Sua eficácia e o impacto do modelo neoliberal. São Paulo: LTR, 1998.

AUER, Peter. Security in labour markets:Combining flexibility with security for decent work. Genebra: OIT, 2007. Disponível em http://www.ilo.org/wcmsp5/groups/public/---ed_emp/--emp_elm/---analysis/documents/publication/wcms_113923.pdf (último acesso em 28/12/2012).

BARROS, Alice Monteiro. Curso de Direito do Trabalho. São Paulo: LTR, 2005.

BARROS JUNIOR, Cássio Mesquita. “O Futuro do Direito do Trabalho”. Palestra proferida no $10^{\circ}$ Congresso Brasileiro de Direito do Trabalho em São Paulo em 16/04/2002, disponível 
em http://www.mesquitabarros.com.br/index.php?option=com content\&view=article\&id=29:o-futuro-dodireito-do-trabalho\&catid=7:artigos\&Itemid=3\&lang=es

BELTRAMELli NETO, Silvio. Limites da Flexibilização dos Direitos Trabalhistas. São Paulo: LTr, 2008.

BONAVIDES, Paulo. Curso de Direito Constitucional. 19a ed., São Paulo: Malheiros, 2006.

BRONZINI, Giuseppe. "Come evitare la "segmentazione" del mercato del lavoro: la filosofia europea della flexicurity e i contratti a termine". in D. \& L - Rivista Critica di Diritto del Lavoro. n. 4, outubro/dezembro de 2008.

BURCHELL, Brendan. Can flexicurity reduce the relationship between job insecurity and psychological well-being? Cambridge: OIT, 2008. Disponível em http://www.ilo.org/wcmsp5/groups/public/---ed_protect/---protrav/--travail/documents/meetingdocument/wcms_123864.pdf (último acesso em 28/12/2012).

BULGUERONI, Renata Orsi. Trabalho Autônomo Dependente: Experiências Italiana e Espanhola e a Realidade Brasileira. Dissertação de Mestrado apresentada junto à Universidade de São Paulo, São Paulo, 2011.

CANOTILHO, José Joaquim Gomes. Direito Constitucional e Teoria da Constituição. $7^{\mathrm{a}}$ ed, Coimbra: Almedina, 2003.

CARELLI, Rodrigo Lacerda. Formas Atípicas de Trabalho. São Paulo: LTR, 2004. (versão digital).

CARUSO, Bruno. "The Future of Labour Law: Traditional Models of Social Protection and a New Constitution of Social Rights”. in W.P. Centro Studi di Diritto Del Lavoro Europeo 
“Massimo D Antona. $\mathrm{n}^{\mathrm{o}}$ 12, 2002. Disponível em http://www.lex.unict.it/eurolabor/ricerca/wp/int/ caruso_n8-2002int.pdf (último acesso em 28/12/2012).

CARVAlHO, Augusto Cesar Leite de. Direito do Trabalho - Curso e Discurso. Aracaju: Evocati, 2011, (versão digital).

CESARINO JUNIOR, Antônio Ferreira. Direito Social Brasileiro. 4a ed., Rio de Janeiro: Freitas Bastos, 1957, V. 1.

CHAHAD; José Paulo Zeetano. Flexible Labour Markets, Workers Protection and Lifelong Learning of the Labour Force in a Global Economy: Latin American and Caribbean Experiences and Perspectives - A Experiência Brasileira. São Paulo, 2008. Disponível em http://www.cepal.org/ de/agenda/1/36021/Jos\%C3\%A9_Paulo_Zeetano_Chahad.pdf (último acesso em 12/01/2013).

- Flexibilidade no mercado de trabalho, proteção aos trabalhadores e treinamento vocacional de força de trabalho: a expêriencia de América Latina e perspectivas (Análise do caso brasileiro). Santiago: ILO, 2009, pág. 120. Disponível em http://www.eclac.org /publicaciones/xml/0/35960/DOC_W_246_Chahad.pdf (último acesso em 12/01/2013).

CHATANI, Kazutoshi. From corporate-centred security to flexicurity in Japan. Genebra: OIT, 2008. Disponível em http://www.ilo.org/public/english/employment/download/ wpaper/wp17.pdf (último acesso em 28/12/2012).

COMISSÃO DAS COMUNIDADES EUROPEIAS. Green Paper Modernising Labour Law to Meet the Challenges of the 21 st Century. Bruxelas: European Comission, 2006.

CORBASCIO, Sergio; NACCI, Onofrio. "Riforma de Mercato del Lavoro e Contrasto al Lavoro Nero". in TIRABOSCHI, Michele (coord). La Riforma Biagi del Mercato del Lavoro. Milano: Giuffrè, 2004. 
COURA, Solange Barbosa de Castro. “O Capitalismo Contemporâneo e suas Transformações - O Impacto da Terceirização Trabalhista”. in Revista LTR. ano 75, v. 12, 2011, págs. $1460 / 1472$.

D`ANTONA, Massimo. "Diritto del Lavoro di Fine Secolo: una crisi d identità". in Rivista Giuridica Del Lavoro. ano 49, n. 1, Roma: Ediesse, 1998, págs. 311/331.

DALLEGRAVE NETO, José Afonso. "Flexissegurança nas Relações de Trabalho. Que bicho é esse?”. in Revista Trabalhista: Direito e Processo. ano 7, n 25: LTR, 2008.

DAVIS, Roberto. "Dissimulação Do Contrato De Trabalho - Algumas Espécies”. in Síntese Trabalhista. $\mathrm{n}^{\circ} 113$, novembro de 1998, pág. 7. (versão digital).

DE MASI, Domenico. Ozio Creativo - Conversazione con Maria Serena Palieri. $3^{\mathrm{a}}$ ed., Milano: BUR Psicologia e Società, 2006.

DELFINO, Massimiliano. "La Contrattazione Colletiva sul Part-Time Dopo il D. LGS. 276/03: Profili Teorici e Applicativi”. in RUSCIANO, Mario; ZOLI, Carlo; ZOPPOLI, Lorenzo (coords.). Istituzioni e Regole del Lavoro Flessibile. Napoli: Editoriale Scientifica, 2006

. Diritti Sociali e flexicurity. Napoli, 2008. Disponível em http://www.europeanrights.eu/ index.php?funzione=S\&op=5\&id=145 (último acesso em 08/01/2013).

DELGADO, Gabriela Neves. Direito Fundamental ao Trabalho Digno. São Paulo: LTR, 2006. 
DELGADO, Maurício Godinho. Curso de Direito do Trabalho. São Paulo: LTr, 2002, pág. 82.

DELGADO, Mauricio Godinho; DELGADO, Gabriela Neves. Constituição da República e Direitos Fundamentais - Dignidade da Pessoa Humana, Justiça Social e Direito do Trabalho. São Paulo: LTR, 2012 (versão digital).

. "A CLT aos 65 Anos: Avaliação Jurídica e Sociocultural”. in Juris Síntese, no 77, maio/junho de 2009. (versão digital).

DI NUNZIO, Potito. "Vincoli e opportunità per le imprese nell 'accesso alle diverse tipologie contrattuali dopo la Riforma Biagi: una rassegna critica”. in TIRABOSCHI, Michele (coord). La Riforma Biagi del Mercato del Lavoro. Milano: Giuffrè, 2004.

ECO, Umberto. Como se Faz uma Tese. 19ª ed., São Paulo: Perspectiva, 2004.

FELICIANO, Guilherme Guimarães. Curso Crítico de Direito do Trabalho. São Paulo: Saraiva, 2012.

- "Direito do Trabalho e Direito dos Contratos: Apontamentos Relevantes Sobre a Parte Especial do Novo Código Civil (Lei ${ }^{\circ} 10.406$, de 10.01.2002)”. in Síntese Trabalhista, $\mathrm{n}^{\mathrm{o}}$ 168, junho de 2003, pág. 25. (versão digital).

FENWICK, Colin; HOWE, John, LANDAU, Ingrid, MARSHAL, Shelly. Labour and Labour-Related Laws in Micro and Small Enterprises: Innovative Regulatory Approaches. Genebra: OIT, 2007. Disponível em http:/www.ilo.org/wcmsp5/groups/public/---ed_emp/--emp_ent/documents/publication/wcms_093618.pdf. (último acesso em 28/12/2012).

FERNANDEZ AVILÉS, José Antonio. El Modelo de "Flexiseguridad" Europeo: Una Aproximación Crític. Palestra proferida no X Congresso Europeu de Direito do Trabalho e da 
Seguridade Social em Sevilha de 21 a 23 de setembro de 2011. Disponível em http://www.europeanrights.eu/public/commenti/fernandez_alviles_testo.pdf (último acesso em 02/01/2013).

FERRARI, Irany. "Reforma Trabalhista". in PRADO, Ney, (coord.). Reforma Trabalhista Direito do Trabalho ou Direito ao Trabalho. São Paulo: LTR, 2001.

FERRARI, Irany. "O Trabalho em Tempos Futuros”. in FERRARI, Irany; MARTINS FILHO, Ives Gandra; NASCIMENTO, Amauri Mascaro, (coord.). História do Trabalho, do Direito do Trabalho e da Justiça do Trabalho - Homenagem a Aramando Casimiro Costa. $3^{\mathrm{a}}$ Ed., São Paulo: LTR, 2011.

FERRARO, Giuseppe. Tipologie di Lavoro Flessibile. Torino, G. Giappichelli, 2009.

FERREIRA FILHO, Manoel Gonçalves. Curso de Direito Constitucional. 24a ed., São Paulo: Saraiva, 1997.

FONSECA, João Bosco Leopoldino. "Globalização e Direito do Trabalho". in Revista do TST, vol. $65, n^{\circ} 1$, outubro/dezembro/1999, pág. 210.

FRANCO FILHO, Georgenor de Souza. "O Trabalho Intelectual na Era da Informação Pejotização - Blogs de Consultas e Contratos de Imagem”. in Revista LTr, ano 75, v. 7, 2011, págs. $836 / 842$.

FREDEIKSEN, Claus Hjort. flexicurity, or How the work force, employers and the government in a small country got together in adapting to market demands in a globalized world. Genebra: OIT, 2008. Disponível em http:/www.ilo.org/wcmsp5/groups/public/ @dgreports/@dcomm/documents/newsitem /wcms_093856.pdf. (último acesso em 01/12/2012). 
FURTADO, Emmanuel Teófilo. "Os Direitos Humanos de $5^{\text {a }}$ Geração Enquanto Direitos à Paz e seus Reflexos no Mundo do Trabalho - Inércias, Avanços e Retrocessos na Constituição Federal e na Legislação". in Direitos Sociais na Constituição de 1988 - Uma análise crítica vinte anos depois. São Paulo: LTR, 2008.

GALANTINO, Luisa. Diritto del Lavoro. 17 ed., Torino: G. Giappichelli, 2010. . "La Finalità della Riforma". in GALANTINO, Luisa (coord.). La Riforma del Mercato del Lavoro. Torino: G. Giappichelli, 2004.

GARCIA, Gustavo Filipe Barbosa. Curso de Direito do Trabalho. São Paulo: Método, 2007.

GAROFALO, Mario Giovanni. "La Legge Delega sul Mercato del lavoro: Prime Osservazioni”. in Rivista Giuridica del Lavoro, ano 54, n. 2, Roma: Ediesse, 2003, págs. $359 / 381$.

GENRO, Tarso. "Um Futuro por Armar". in Revista Democracia e Mundo do Trabalho, novembro/1998.

GHIONE, Hugo Barretto. "La Determinación de la relación de trabajo em la Recomendación 198 y el fin del discurso único de la subordinación jurídica". in Revista Trabalhista: Direito e Processo, ano 7, nº 25: LTR, 2008.

GIUDICE, Federico Del; MARIANI, Federico; IZZO, Fausto. Diritto del Lavoro. Napoli: Simone, 2006.

GODOY, Dagoberto Lima. Flexisseguridade no Brasil. São Paulo: LTR, 2010.

GOLDSCHIMIDT, Rodrigo. Flexibilização dos Direitos Trabalhistas - Ações afirmativas da dignidade da pessoa humana como forma de resistência. São Paulo: LTR, 2009. 
GOMES, Antonio Cleto. "Das Negociações Coletivas de Trabalho - Flexibilização das Leis Trabalhistas - Soluções Jurídicas Inteligentes para Tempos de Crise Econômica”. in Juris Síntese, $\mathrm{n}^{\mathrm{o}} 89$, maio/junho de 2011.

GONÇALVES, Leandro Krebs. "Os Direitos Constitucionais do Trabalhador Autônomo”. in Cadernos da Amatra IV, ano V, no 14, novembro/2010.

GUERRA, Guillermo López. "Garantismo e Flexibilidade na Legislação do Direito do Trabalho da América Latina. Direitos Trabalhistas e a Flexibilidade”. in PERONE, Gian Carlo; SCHIPANI, Sandro, (coords.). Princípios para um Código-Tipo de Direito do Trabalho para a América Latina. São Paulo: Ltr, 1996.

HARVEY, David. The Enigma of Capital and the Crisis of Capitalism. $2^{\mathrm{a}}$ ed., London, Profile Books, 2011.

HOBSBAWM, Eric. A era dos Extremos - O breve século XX-1914-1991. $2^{\mathrm{a}}$ ed., São Paulo: Companhia das Letras, 2010.

HYDE, Alan. "Employee Organization and Employment Law in the Changing US Labor Market: America Moves Toward Shorter-Time Jobs”. in W.P. Centro Studi di Diritto Del Lavoro Europeo "Massimo D`Antona, no 10, 2002, pág. 19. Disponível em http://www.lex.unict.it/eurolabor/ricerca/wp/int/hyde_n10-2002int.pdf (último acesso em 27/12/2012).

JEAMMAUD, Antoine. "Direito do Trabalho em Transformação: Tentativa de Avaliação". (tradução de Joaquim Leonel de Rezende Alvim), in Revista da Faculdade de Direito da UFF, no 1, 1998, pág. 09.

JHA, Praveen; SAKTI, Golder. Labour Market Regulation and Economic Performance: A Critical Review of Arguments and Some Plausible Lessons for India. Genebra: OIT, 2008, 
pág. 34. Disponível em http://www.ilo.org/wcmsp5/groups/public/---ed_emp/---emp_elm/--analysis/documents/ publication/wcms_ 113926.pdf (último acesso em 28/12/2012).

KLAMMER, Ute. "flexicurity Schemes". in Recounciling Labour Flexibility with Social Cohesion - Facing the Chalenge, Trends in Social Cohesion, $\mathrm{n}^{\mathrm{o}}$ 15: Council of Europe Publishing, 2005.

LENZA, Pedro. Direito Constitucional Esquematizado. 12ª ed., São Paulo: Saraiva, 2008.

MADSEN, Per Kongshoj. "The Danish Model of 'flexicurity': A Paradise With Some Snakes". in SARFATI, Hedva; BONOLI, Giuliano, (coords). Labour Market and Social Protection Reforms in International Perspective. Aldershot: Ashgate, 2002

MANNRICH, Nelson. Autonomia, Parassubordinação e subordinação: os Diversos niveis de proteção do trabalhador e do Teletrabalhador. Disponível em http://www.mackenzie.br/fileadmin/Graduacao/ FDir/Artigos/nelson_manrich.pdf. (último acesso em 02/01/2013).

. "Limites da Flexibilização das Normas Trabalhistas". in Revista do Advogado, Associação dos Advogados de São Paulo no 54, dezembro de 1998.

MARIUCCI, Luigi. "Changes in Employment and Labour Law". in Recounciling Labour Flexibility with Social Cohesion - Facing the Chalenge, Trends in Social Cohesion, $\mathrm{n}^{\mathrm{o}}$ 15: Council of Europe Publishing, 2005.

MARTINS, Sergio Pinto. "A OIT e a Globalização". in Juris Síntese, n 78, julho/agosto de 2009. (versão digital).

. Flexibilização das Condições de Trabalho. $4^{\mathrm{a}}$ ed., São Paulo: Atlas, 2009. 
MASSIMIANI, Clemente. "flexicurity and Decent Work in Europe: can they co-exist?". in W.P. Centro Studi di Diritto Del Lavoro Europeo “Massimo D`Antona, no 65, 2008, pág. 5. Disponível em http://www.lex.unict.it/eurolabor/ricerca/wp/int/massimiani_n65-2008int.pdf (último acesso em 30/12/2012).

MENEZES, Claudio Armando Couce. "Os Novos Contornos das Relações de Trabalho e de Emprego - Direito do Trabalho e a Nova Competência Trabalhista Estabelecida pela Emenda $\mathrm{n}^{\mathrm{o}}$ 45/04". in Juris Síntese, $\mathrm{n}^{\circ}$ 56, outubro/novembro de 2005.

MERÇON, Paulo Gustavo de Amarante. "Direito do Trabalho Novo". in Revista LTR, ano 75, v. 01, 2011, pág. 86/94.

MINISTÉRIO DO TRABALHO E EMPREGO. Agenda Nacional de Trabalho Decente. Brasília: 2006. Disponível em http://portal.mte.gov.br/data/files/ 8A7C816A2E7311D1012EFD9027785D9E/Agenda\%20Nacional\%20do\%20Trabalho \%20Decente\%20em\%20Portugu\%C3\%AAs.pdf. (último acesso em 10/12/2012).

MITRA, Devashish; RANJAN, Priya. "Social protection in labour markets exposed to external shocks" in BACCHETTA, Marc; JANSEN, Marion (coord.). Making Globalization Socially Sustainable. Genebra: OIT, 2011. Disponível em http://www.ilo.org/wcmsp5/groups/public/--dgreports/---dcomm/---publ/documents/publication/wcms_144904.pdf (último acesso em $30 / 12 / 2012)$.

MORAES, Alexandre de. Direito Constitucional. 13ª ed., São Paulo: Atlas, 2003.

MOREIRA, Airton Rodrigues. "O Eterno Conflito Capital X Trabalho: Qual Modernização Necessária”. in Juris Síntese, nº 88, março/abril de 2011.

NAHAS, Thereza Christina. "Considerações a Respeito da Relação de Trabalho: A Questão do Trabalho Semidependente". in Juris Sintese, n 69, janeiro/fevereiro de 2007. 
NASCIMENTO, Amauri Mascaro. Iniciação ao Direito do Trabalho. 27a ed., São Paulo: LTR, 2001

. Curso de Direito do Trabalho. 16ª ed., São Paulo: Saraiva, 1999. . Direito do Trabalho na Constituição de 1988. São Paulo: Saraiva, 1989. . "Mudanças no Mercado de Trabalho". in RODRIGUES, Aluisio, (coord.). Direito Constitucional do Trabalho. São Paulo: LTR, 1993.

NASCIMENTO, Ricardo. "Flexisegurança ou Flexibilizar a Insegurança?". in Revista O Advogado, $\mathrm{n}^{\circ}$ 36, 2007 disponível em www.oadvogado.direitonline.com/ artigo/artigo.asp? $\mathrm{id}=36$.

ORGANIZAÇÃO INTERNACIONAL DO TRABALHO, Instituto Internacional de Estudos do Trabalho. Brasil: Uma Estratégia Inovadora Alavancada pela Renda. Genebra: OIT, 2011.

PAGANI, Marcella; e RENAULT, Luiz Otávio Linhares. “'Para uma Proteção Além do Trabalho". in Revista LTR, ano 76, v. 02, 2012, págs. 170/175.

PEDUZZI, Maria Cristina Irigoyen. “O Princípio da Dignidade da Pessoa Humana e Sua Eficácia Concreta". in MANNRICH, Nelson et. al. (coords.). Reconstrução do Direito do Trabalho - Anais da Academia Nacional de Direito do Trabalho 2010. São Paulo: LTR, 2010.

PEREIRA, José Luciano de Castilho. "Futuro do Direito e do Processo do Trabalho no Brasil”. Conferência proferida no XX Encontro Anual dos Magistrados da Justiça do Trabalho da $\quad 2^{\text {a }}$ Região em 31/10/2004, disponível em www3.tst.jus.br/ ArtigosJuridicos/gmlcp/futurododireitoedoprocessodotrabalho.pdf 
PERULLI, Adalberto. Social rights and administrative regulations for effectiveness and sustainability: What modernization of labour law?. Genebra: OIT, 2012.

PESSOA, Flavia Moreira Guimarães. "A Globalização e Concretização dos Direitos Trabalhistas Fundamentais". in Revista Jurídica da Amatra da $17^{a}$ Região, ano V, $\mathrm{n}^{\mathrm{o}}$ 9, julho/2008. (1)

- "A Tutela das Relações de Trabalho em Sentido Amplo Por Meio de Hermenêutica Constitucional Concretizadora dos Direitos Trabalhistas Fundamentais Individuais". in Direitos Sociais na Constituição de 1988 - Uma análise crítica vinte anos depois, São Paulo: LTR, 2008. (2)

PINTO, Airton Pereira. Direito do Trabalho, Direitos Humanos Sociais e a Constituição Federal. São Paulo: LTR, 2006.

PORTO, Lorena Vasconcelos. "A Necessidade de uma Releitura Universalizante do Conceito de Subordinação". in Juris Síntese, nº 73, setembro/outubro de 2008. (versão digital).

REGINO, Marino. "Tendenze comuni e differenze nella regolazione del mercato del lavoro e delle relazioni industriali in Europa". in W.P. Centro Studi di Diritto Del Lavoro Europeo "Massimo D`Antona", $\quad \mathrm{n}^{\mathrm{o}} \quad 7,2002 . \quad$ Disponível em http://www.lex.unict.it/eurolabor/ricerca/wp/int/regini_n7-2002int.pdf (último acesso em 26/12/2012).

RIBEIRO, Francisco. "Direito do Trabalho: flexibilização ou desregulamentação?". in Revista Jurídica da Amatra da $17^{a}$ Região, ano IV, $\mathrm{n}^{\circ}$ 8, maio/2007.

RIFKIN, Jeremy. O Fim dos Empregos. 2a ed., São Paulo: M. Books do Brasil., 2004. 
ROMITA, Arion Sayão. Flexigurança - A Reforma do Mercado de Trabalho. São Paulo: LTR, 2008.

Direitos Fundamentais nas Relações de Trabalho. 4ª ed., São Paulo: LTR, 2012.

RUZZENENTI, Valentina. "Lavoro Intermittente". in FAVALI, Giacinto (coord.). Codice di Diritto del Lavor., $5^{\text {a }}$ ed., Piacenza: CELT, 2011.

SANTORO-PASSARELI, Giuseppe. "Competitività e flessibilità del rapporto di lavoro". in Rivista Italiana di Diritto del Lavoro, ano 28, v. 1, Milano: Giuffrè, 2009, págs. 201/219.

. "Flessibilità e Rapporti di Lavoro". in SANTORO-PASSARELLI, Giuseppe (coord.). Flessibilità e Diritto del Lavoro. v. III, Torino: G. Giappichelli, 1997.

SANTOS, José Aparecido dos. Fundamentos da Subordinação Jurídica do Trabalhador: Sujeição e Construção da Cidadania. Dissertação de Mestrado apresentada junto à Pontifícia Universidade Católica do Paraná, Curitiba, 2009.

SANTOS, Maria Marta Vieira dos. "O Princípio Protetor Frente À Nova Competência Da Justiça Do Trabalho". in Juris Síntese, n 54, julho/agosto de 2005.

SANTUCCI, Rosario. "Il Lavoro Intermittente: Un Modello Contrattuale Inutilizato (E Inutilizzabile) di Lavoro Iperflessibile?". in Rusciano, Mario; ZOLI, Carlo; ZOPPOLI, Lorenzo (coords.). Istituzioni e Regole del Lavoro Flessibile. Napoli: Editoriale Scientifica, 2006.

SARLET, Ingo Wolfgang. A Eficácia dos Direitos Fundamentais. 6 ${ }^{\mathrm{a}}$ ed., Porto Alegre: Livraria do Advogado, 2006. 
. "Os Direitos Sociais como Direitos Fundamentais: Seu Conteúdo, Eficácia e Efetividade no Atual Marco Jurídico-Constitucional Brasileiro". in Cadernos da Amatra IV, ano IV, $\mathrm{n}^{\circ}$ 10, janeiro/março/2009.

. "Algumas Notas a Respeito dos Direitos Fundamentais Sociais e a Proibição de Retrocesso: Desafios e Perspectivas". in Cadernos da Amatra IV, ano V, n 13 , junho/2010.

SCHINESTSCK, Clarisse Ribeiro. "A Declaração da OIT sobre Princípios e Direitos Fundamentais e a Promoção do Trabalho Decente". in BELTRAN, Ari Possidonio (coord). União Europeia e o Direito do Trabalho. São Paulo: LTR, 2012.

SEVERO, Valdete Souto. "O Mundo do Trabalho e a Flexibilização". in Direitos Sociais na Constituição de 1988 - Uma análise crítica vinte anos depois. São Paulo: LTR, 2008.

SHARKH, Miriam Abu. Are there optimal global configurations of labour market flexibility and security?- Tackling the flexicurity oxymoron. Genebra: OIT, 2008. Disponível em http://www.ilo.org/wcmsp5/groups/public/---ed_emp/---emp_elm/-analysis/documents /publication/wcms_ 105 102.pdf (último acesso em 28/12/2012).

SILVA, Homero Batista Mateus da Silva. Curso de Direito do Trabalho Aplicado - Parte Geral. Rio de Janeiro: Elsevier, 2009.

SILVA, José Afonso da. Curso de Direito Constitucional Positivo. $15^{\mathrm{a}}$ ed., São Paulo: Malheiros, 1998.

SILVA, Otávio Pinto e. Subordinação, Autonomia e Parassubordinação nas Relações de Trabalho. São Paulo: LTR, 2004. (versão digital). 
SIQUEIRA NETO, José Francisco. "Desregulamentação e Flexibilização do Direito Do Trabalho - Uma Abordagem Preliminar”. in Revista Direito Mackenzie, n 1, 2000, págs. $51 / 61$.

SOUTO MAIOR, Jorge Luiz. "Valores Fundamentais do Direito Social". Cadernos da Amatra IV, ano III, $\mathrm{n}^{\mathrm{o}} 7$, abril/junho/2008.

. "Direito do Trabalho e Desenvolvimento Econômico - Um Contraponto à Teoria da Flexibilização”. in Juris Síntese, no 18, julho/agosto de 1999.

SUSSEKIND, Arnaldo. "Os Direitos Constitucionais Trabalhistas”. in Direitos Sociais na Constituição de 1988 - Uma análise crítica vinte anos depois. São Paulo: LTR, 2008.

TAVARES, Andre Ramos. Curso de Direito Constitucional. $5^{\mathrm{a}}$ ed., São Paulo: Saraiva, 2007.

URIARTE, Oscar Ermida. "A Flexibilização do Direito do Trabalho na Experiência LatinoAmericana". in Revista da Escola da Magistratura do Tribunal Regional do Trabalho da $2^{a}$ Região, ano I, $\mathrm{n}^{\mathrm{o}}$ 1, setembro/2006.

VALDES AlONSO, Alberto. Derecho Del Trabajo, Rse Y Flexiguridad En El Seno De La Unión Europea: Una Difícil Convivência. Palestra proferida no X Congresso Europeu de Direito do Trabalho e da Seguridade Social em Sevilha de 21 a 23 de setembro de 2011, pág. 6. Disponível em http://www.europeanrights.eu/public/commenti/valdes_alonso_testo.pdf (último acesso em 02/01/2013).

VAlleBonA, Antonio. Breviario di Diritto del Lavoro. $6^{\mathrm{a}}$ ed., Torino: G. Giappichelli, 2010.

VIANNA, José de Segadas SÜSSEKIND, Arnaldo; MARANHÃO, Délio; TEIXEIRA, João de Lima. Instituições de Direito do Trabalho.v. 1., 20ª ed., São Paulo: LTr, 2002. 
VIEBROCK, Elke; CLASEN, Jochen. "State of the Art - flexicurity and Welfare Reform: a Review”. in Socio-Economic Review, v. 7, issue 2: Oxford, 2009.

VILHENA, Paulo Emílio Ribeiro de. Relação de Emprego: Estrutura Legal e Supostos. São Paulo: Saraiva, 1975.

VITORINO, Adriana. “'CLT FLEX' - A Nova Modalidade de Fraude”. in Revista LTr, ano 76, v. 04, 2012, págs. 463/468.

WILTHAGEN, Ton; e TROS, Frank. "The Concept of flexicurity: A New Approach to Regulating Employment and Labour Markets”. in flexicurity: Conceptual Issues and Political Implementation in Europe. TRANSFER: European Review of Labour and Research, vol. 10, $\mathrm{n}^{\mathrm{o}} .2 ., 2004$.

WILTHAGEN, Ton (coord.). flexicurity Practices. Bruxelas: European Commission, 2007, disponível em http://ec.europa.eu/employment_social/employment_strategy/pdf/ flexi_practices_en. (último acesso em 30/11/2012).

ZAPPALÀ, Loredana. Flessicurezza, Pari Opportunita' E Non Discriminazione: I Percorsi (Quasi Sempre) Virtuosi Delle Politiche E Del Diritto Sociale Europeo. 2008. Disponível em http://www.europeanrights.eu/index.php?funzione=S\&op=5\&id=201 (último acesso em 10/01/2013).

ZYLBERSTAJN, Hélio. Novos Padrões de Negociação Coletiva: Perspectivas do Contrato Coletivo de Trabalho no Brasil. Painel de Debates coordenado por Marco Antônio de Oliveira. Disponível em http://www.cebrap.org.br/v1/upload/biblioteca_virtual/NOVOS PADROES_DE_NEGOCIACAO_COLETIVA_PERSPECTIVAS.pdf (último acesso em 03/01/2013). 
. "Aspectos Econômicos da Redução da Jornada de Trabalho". in MANNRICH, Nelson et. al. (coords.). Reconstrução do Direito do Trabalho - Anais da Academia Nacional de Direito do Trabalho 2010. São Paulo: LTR, 2010 